\begin{tabular}{|c|c|c|}
\hline Beitr. Ent. & Keltern & ISSN 0005-805X \\
\hline $\mathbf{5 9}(2009) 2$ & S. $355-422$ & 15.12 .2009 \\
\hline
\end{tabular}

\title{
A revision of Ceranota STEPHENS, subgenus of Aleochara GrAVENHORST
}

\section{(Coleoptera: Staphylinidae: Aleocharinae)}

With 171 figures and 4 maps

VOLKer Assing

Summary

Types and additional material of the species of the Aleochara subgenus Ceranota Stephens, 1839 are revised. In all, 30 species are recognised, including four species of doubtful status, whose type material is either lost or inaccessible, or whose male sexual characters are unknown. The known distribution of the subgenus is confined to the Western Palaearctic region, eastwards to Afghanistan. Diagnoses of the subgenus, as well as of the individual species are provided. The following synonymies are proposed: Aleochara penicillata Peyerimhoff, $1901=$ A. caprae Gridelli, 1922, syn. n. $=$ A. meschniggi Bernhauer, 1943, syn. n.; A. strasseri Bernhauer, $1901=$ A. matzenaueri Rambouser, 1907, syn. $\mathrm{n}$. Aleochara conviva Eppelsheim, 1878, previously a synonym of $A$. lurida Motschulsky, 1860, and $A$. consors Eppelsheim, 1890 , previously a synonym of $A$. adusta Eppelsheim, 1890, are revalidated. Aleochara tuberiventris KraAtz, 1859 is excluded from the subgenus. Neotypes are designated for Aleochara ruficornis Gravenhorst, 1802, A. erythroptera Gravenhorst, 1806, A. major Fairmaire, 1858, A. caprae Gridelli, 1922, and A. matzenaueri Rambouseк, 1907. Lectotypes are designated for Aleochara diversicollis Fauvel, 1900, A. melichari (Reitter, 1889), A. meschniggi Bernhauer, 1943, A. opacina Fauvel, 1900, A. adusta Eppelsheim, 1890, A. consors Eppelsheim, 1890, and A. libanica Eppelsheim, 1889. Four species are described and illustrated for the first time: Aleochara (Ceranota) virilis sp. n. (Russia: Adygeya), $A .(C$.) claviculata sp. n. (NE-Turkey), A. (C.) sarica sp. n. (Iran: Mazandaran), and A. (C.) feldmanni sp. n. (Afghanistan). Zoogeographic and bionomic data are compiled. Additional records of Ceranota species are reported, among them numerous new country records. The distributions of eight species are mapped. A key to species and a catalogue are provided.

Key words

Staphylinidae, Aleocharinae, Aleochara, Ceranota, Palaearctic region, taxonomy, new species, revalidation, new synonymies, descriptions, redescriptions, neotype designations, lectotype designations, distribution, new records

\section{Zusammenfassung}

Typen und weiteres Material der Arten der Aleochara-Untergattung Ceranota Stephens, 1839 werden revidiert. Nach der Revision umfasst die Untergattung insgesamt 30 Arten, darunter vier Arten von zweifelhaftem Status, deren männliche Geschlechtsmerkmale unbekannt sind oder deren Typenmaterial entweder verschollen oder nicht verfügbar ist. Die Verbreitung von Ceranota ist auf die Westpaläarktis östlich bis Afghanistan beschränkt. Für die Untergattung sowie für die einzelnen Arten werden (Kurz-)Beschreibungen gegeben. Folgende Synonymisierungen werden vorgenommen: Aleochara penicillata Peyerimhoff, 1901 
= A. caprae Gridelli, 1922, syn. n. = A. meschniggi Bernhauer, 1943, syn. n.; A. strasseri Bernhauer, 1901 = A. matzenaueri Rambousek, 1907, syn. n. Aleochara conviva EppelsheIm, 1878, bisher Synonym von $A$. lurida Motschulsky, 1860, und $A$. consors Eppelsheim, 1890, bisher Synonym von $A$. adusta EpPelsheim, 1890, werden revalidiert. Aleochara tuberiventris Kratz, 1859 wird aus der Untergattung ausgeschlossen. Für Aleochara ruficornis Gravenhorst, 1802, A. erythroptera Gravenhorst, 1806, A. major Fairmaire, 1858, A. caprae Gridelli, 1922 sowie A. matzenaueri Rambousek, 1907 werden Neotypen designiert. Für Aleochara diversicollis Fauvel, 1900, A. melichari (Reitter, 1889), A. meschniggi Bernhauer, 1943, A. opacina Fauvel, 1900, A. adusta Eppelsheim, 1890, A. consors Eppelsheim, 1890 und A. libanica Eppelsheim, 1889 werden Lectotypen designiert. Vier Arten werden erstmals beschrieben und abgebildet: Aleochara (Ceranota) virilis sp. n. (Russland: Adygeja), A. (C.) claviculata sp. n. (NO-Türkei), A. (C.) sarica sp. n. (Iran: Mazandaran) und $A$. (C.) feldmanni sp. n. (Afghanistan). Zoogeographische und bionomische Daten werden zusammengestellt. Weitere Nachweise von CeranotaArten werden gemeldet, darunter zahlreiche Erstnachweise. Die Verbreitung von acht Arten wird anhand von Karten illustriert. Eine Bestimmungstabelle und ein Katalog der Arten werden vorgelegt.

\section{Introduction and taxonomic history}

Ceranota was originally described as a distinct genus by STEPHens (1839) to include only the type species $C$. daltoni STEPHens, 1832 (today a junior synonym of Aleochara ruficornis Gravenhorst, 1802). The taxon was continued to be regarded as a genus by subsequent authors (e.g., Mulsant \& ReY 1874, ReITTER 1889) up until approximately the turn of the century, when it was attributed to Aleochara Gravenhorst, 1802 as a subgenus (EPPELSHeim 1889a, 1890a, 1890b, FAuvel 1900, Ganglbauer 1895, Bernhauer 1901, Bernhauer \& Scheerpeltz 1926). Ganglbauer (1895) included only four species in Ceranota. In a synopsis of all the Palaearctic representatives of Aleochara, Bernhauer (1901) keyed and (re-)described 16 Ceranota species. Twenty-five years later, the subgenus included 22 species (Bernhauer \& Scheerpeltz 1926), 21 of them from the Western Palaearctic region and one, A. tuberiventris KraAtz, 1859, from the Oriental region ("India orientali") (KraATz 1859). The next synopsis was published by Roubal (1937), who keyed the 25 Palaearctic species known at the time. More recent keys, at the same time the only keys providing illustrations to the primary sexual characters, to the six Central European species were provided by Likovskí (1974) and Vogel (1998). The Ceranota species of Turkey were recently dealt with by Assing (2007, 2009). Between 1937 and 2004, no additional taxa were described. According to the recent Palaearctic Catalogue (Smetana 2004), Ceranota included 25 valid species and nine synonyms. In the meantime, four more species have been described from the Eastern Mediterranean, one from Greece and three from Turkey (Assing 2006a, 2007, 2009).

The species of Ceranota have attracted the attention of taxonomists and collectors for several reasons. All of them are considered rare or extremely rare; some of them are still represented only by their respective (holo-)types. Records are usually more or less coincidental, since the true reproduction habitat is essentially unknown. Moreover, most species have remarkable modifications such as tubercles or other processes of various shapes on the dorsal side of the abdomen, especially in the male, as well as patches with conspicuous long pubescence on the ventral side of the male abdomen.

In the present paper, some poorly known species are redescribed and illustrated, based on a revision of types and additional material. Also, four new taxa from Turkey, Russia, Iran, and Afghanistan are described. Moreover, new data on the ecology and distribution of several species are presented, and a new key to the Palaearctic representatives of the subgenus, as well as a catalogue are provided. 


\section{Material, methods, and depositories}

The material treated in the present study is deposited in the following public institutions and private collections:

$\begin{array}{ll}\text { FMNH } & \text { Field Museum of Natural History, Chicago (J. Boone, A. F. Newton, Jr.) } \\ \text { HNHM } & \text { Hungarian Natural History Museum, Budapest (Gy. Makranczy) } \\ \text { IRSNB } & \text { Institut Royal des Sciences Naturelles de Belgique, Bruxelles (Y. Gérard) } \\ \text { MCSNT } & \text { Museo Civico di Storia Naturale, Trieste (A. Colla) } \\ \text { MNHUB } & \text { Museum für Naturkunde der Humboldt-Universität Berlin (J. Frisch, J. Willers) } \\ \text { NHMW } & \text { Naturhistorisches Museum Wien (H. Schillhammer) } \\ \text { SDEI } & \text { Senckenberg Deutsches Entomologisches Institut, Müncheberg (L. Behne, L. Zerche) } \\ \text { TAU } & \text { National Museum of Natural History, Tel Aviv University (A. Freidberg, via B. Feldmann) } \\ \text { ZMMU } & \text { Zoological Museum of Moscow State University (A. Gusakov) } \\ \text { cAss } & \text { author's private collection } \\ \text { cFel } & \text { private collection B. Feldmann, Münster } \\ \text { cPüt } & \text { private collection A. Pütz, Eisenhüttenstadt } \\ \text { cRen } & \text { private collection K. Renner, Bielefeld } \\ \text { cSch } & \text { private collection M. Schülke, Berlin } \\ \text { cShm } & \text { private collection L. Schmidt, Hannover } \\ \text { cTro } & \text { private collection M. Tronquet, Molitg-les-Bains } \\ \text { cVai } & \text { private collection D. Vailati, Brescia } \\ \text { cWun } & \text { private collection P. Wunderle, Mönchengladbach }\end{array}$

The morphological studies were conducted using a Stemi SV 11 microscope (Zeiss Germany) and a Jenalab compound microscope (Carl Zeiss Jena). For the photographs a digital camera (Nikon Coolpix 995) was used. The maps were generated using the online generic mapping tool (GMT) of the Geomar website at www.aquarius.ifm-geomar.de/omc.

Head length was measured from the anterior margin of the clypeus (without the membranous portion) to the posterior margin (constriction) of the head; elytral length at the suture, from the apex of the scutellum to the posterior elytral margin; the length of the median lobe of the aedeagus from the apex of the ventral process to the base of the median lobe. The terminology of the anatomy of the spermatheca is primarily based on Marzo (2007).

\section{The subgenus Ceranota Stephens, 1839}

Ceranota Stephens, 1839: 351; type species: Aleochara daltoni Stephens, 1832.

Hoplonotus Sснміdт-GöвеL, 1846: 245; type species: Hoplonotus laminatus SCHмidt-GöвeL, 1846. Sorecocephala Bernhauer, 1902: 245; type species Ocalea reitteri Bernhauer, 1900.

\section{Diagnosis:}

Body length variable, 3.5-10.5 mm; body often of slender habitus. Coloration variable; head, pronotum, and abdomen usually at least partly darkened, often with at least the pronotal margins, the anterior abdominal segments, and the abdominal apex reddish; elytra reddish to yellowish, occasionally with the postero-lateral angles and the scutellar region more or less extensively darkened.

Head with weakly convex and small to moderately large eyes. Latero-ventral carina fully developed, i.e., anteriorly not obsolete, often pronounced. Anterior margin of clypeus more or 
less extensively membranous, in some species clypeus completely membranous (Figs 113-115). Antennae in most species slender and weakly incrassate apically; antennomere X usually clearly less than twice as wide as long (e.g., Figs 118, 124, 132), rarely short and with antennomeres VI-X approximately twice as wide as long. Mesoventrite without median carina, at most with short rudiment of such a carina anteriorly; process of mesoventrite very long, slender, and acute. Elytra of variable length; posterior margins weakly sinuate near posterior angles. Hind wings fully developed or dimorphic. Abdomen with segments III-VII subparallel to distinctly tapering posteriad; tergites III-V with deep to moderately deep anterior impressions; tergite VI with weaker, sometimes indistinct anterior impression.

$\sigma^{\star}$ : tergites III, IV, and/or VII often - other tergites rarely - with modifications (tubercles, processes, transverse ridges, etc.); sternites IV and V in few species unmodified, often more or less distinctly impressed, these impressions with more or less pronounced patches of dense, grey, white, or golden setae (Figs 76-103); posterior margin of sternite VIII obtusely to acutely pointed in the middle (e.g., Fig. 107). Aedeagus with median lobe of rather uniform shape, ventral process not, or only slightly longer than basal portion; internal sac with straight tube of moderate length, usually not reaching basal portion of median lobe, and with pair of oblong, distinctly sclerotised apical structures (Figs 1-51); apical lobe of paramere not conspicuously elongated, approximately 1/4-1/3 the length of basal portion of paramere.

9 : tergites III, IV, and/or VII with or without modifications (if present, they are usually on average less pronounced than in male); sternites IV and V unmodified; sternite VIII posteriorly weakly convex and with relatively short stout marginal setae. Spermatheca of rather uniform shape (Figs 52-75).

The best characters for distinguishing Ceranota from other subgenera of Aleochara are the modifications (if present) of the abdominal tergites, the modifications of the male sternites IV and V (if present), and particularly the morphology of the median lobe of the aedeagus (shape, internal structures) and the characteristic, rather uniform shape of the spermatheca. Additional characters are the often slender habitus, the often relatively slender head, as well as the mostly reddish to yellowish coloration of the elytra (sometimes also of the pronotum and the abdomen).

The modifications of the abdominal tergites are subject to pronounced intraspecific variation. They tend to be fully pronounced only in large specimens, mostly males, and nearly or completely obsolete in very small specimens.

\section{Taxonomy and identification:}

The taxonomic state and interpretation of a considerable proportion of the Ceranota species is problematic for several reasons. Firstly, the type material of some species is either lost, or of unknown whereabouts, or currently inaccessible due to restrictive loan policies of the institutions where it is deposited. Secondly, the original descriptions of several species are based on females, although in regions with a high diversity of species (Eastern Mediterranean, Caucasus, etc.) identificaton primarily or exclusively relies on the male sexual characters, and males from the vicinity of the respective type localities matching the descriptions are unknown. Thirdly, Ceranota species are found rarely and usually as single specimens. In addition, like other Aleochara with a parasitoid life history, they are subject to enormous intraspecific variation of body size and other characters, and the modifications of the male abdominal tergites are generally pronounced only in larger specimens. Nevertheless, several original descriptions are based on single males from the lower end of the size range and with probably reduced secondary sexual characters, so that taxonomically signficant characters are difficult to assess. 
In consequence, while the taxonomic state of the Ceranota fauna of Europe to the west and northwest of Turkey may be considered fairly stable and well-documented, the same cannot be said for the fauna of Turkey, the Caucasus region, and adjacent regions. The taxonomic state of some species from these regions is still at least somewhat uncertain, and the possibility of future synonymies and discoveries of additional species cannot be ruled out. Also, identification of material particularly from the Caucasus region and Turkey is still somewhat problematic.

\section{Diversity and distribution:}

Including the new species described in this paper, the subgenus comprises 30 species. All of them are distributed in the Western Palaearctic eastwards to Afghanistan. No Ceranota species are known from North America (Klimaszewski 1984) and from the Eastern Palaearctic east of Afghanistan (Smetana 2004). The diversity is highest in the Balkans, Turkey, the Caucasus region, and adjacent regions.

Additional material (females) of several probably undescribed species was seen from Turkey, suggesting that the true diversity of Ceranota in this region may be higher than currently known.

Based on the morphology and chaetotaxy of the male abdominal sternites IV and V, two species groups can be distinguished. In the A. ruficornis group, which includes the majority of species and whose distribution ranges from southwestern Europe eastwards to the Caucasus region, these sternites have more or less defined and more or less transverse, oval, or kidney-shaped areas with pronounced microsculpture and dense long pubescence (Figs 76-103); it seems likely that these structures are connected to glands and involved in the secretion of sex pheromones. These modifications are absent in the $A$. subtumida group, which comprises a few species distributed in the region from Turkey eastwards to Afghanistan. For additional characters separating both species groups see the key at the end of the paper. Within the $A$. ruficornis group, a subgroup containing four species ( $A$. hydrocephala, A. opacina, A. strasseri, A. membranosa) with a conspicuous synapomorphy, a completely semi-membranous clypeus (Figs 113-115), can be identified.

While some species (e.g., A. ruficornis, A. erythroptera) are remarkably widespread, many other representatives of the subgenus have more or less restricted distributions. However, owing to the rarity of records, the actual distributions of most species require clarification.

\section{Bionomics:}

The habitats of Ceranota species have been - and still are - the subject of speculation. Since almost all the species are found rarely or extremely rarely and usually in single specimens under various circumstances, they have been suspected to be associated with ants (PEYERIMHOFF 1901, Peyerimhoff \& Sainte-Claire Deville 1901) or subterranean mammal burrows (Horion 1967, Roubal 1937). Since ant nests have been subject to extensive studies, but never yielded Ceranota in appreciable numbers, there is no substantial evidence supporting the former hypothesis. Similarly, studies on the nest fauna of moles, voles, and other mammals with subterranean burrows have produced no significant quantities of specimens either. Ceranota species have been found in various, both forested and unforested biotopes, mostly at intermediate and higher altitudes, in a great variety of habitats: decaying organic substrates (rotting wood, excrements, flood debris, etc.), in nests of various mammals and ants, in dens and stables, in hollow trees, on snow, and in the leaf litter; they have also been swept from grass and collected at window panes. For detailed compilations of collection data see Horion (1967) and Roubal (1937).

On one occasion, as many as 12 specimens (of $A$. mortuisimilis) were sifted from leaf litter near snow (Assing 2006a). Otherwise, species of Ceranota have been found in larger numbers exclusively with pitfall traps, mostly during a relatively short time span, suggesting that they are epigei- 
cally active only during their dispersal period and that reproduction occurs in a cryptic subterranean habitat (Assing 1994). In this respect, their phenology is similar to that of other aleocharine genera such as Callicerus Gravenhorst, 1802, Pseudosemiris Machulka, 1935, and Alevonota Thomson, 1858 of the Athetini, as well as Ilyobates KraAtz, 1856 and Amarochara Thomson, 1858 of the Oxypodini (Assing 1999, 2001b, 2002, Assing \& Wunderle 2008). Some species are epigeically active in spring and summer (e.g., A. ruficornis, A. erythroptera), while others are only recorded in the cold season (e.g., A. penicillata, A. major) (Assing 1994, Horion 1967).

The vast majority of species seem to be fully winged, and some species have often been collected on the wing. Dissection of the thorax of specimens of $A$. ruficornis revealed, however, that at least in this species flight muscles are often reduced and that consequently part of the population is incapable of flight (Assing 2004). One species, A. mortuisimilis, is wing-dimorphic and displays thanatosis when moved or touched (Assing 2006a).

The dipteran hosts of Ceranota species are unknown (Maus et al. 1998), but the pronounced variation of body size suggests that, like species of other subgenera of Aleochara (probably except species of the subgenus Heterochara Mulsant \& REY, 1874), their larvae are ectoparasitoids of puparia of cyclorrhapheous Diptera.

\section{The species of Ceranota}

Detailed (re-)descriptions and illustrations of $A$. erythroptera, $A$. mortuisimilis, $A$. caloderoides, and A. simplicicornis have been published elsewhere (Assing 2006a, 2007, 2009) and are not repeated below.

\section{Aleochara (Ceranota) ruficornis Gravenhorst, 1802 (Figs 1-3, 53, 76-77)}

Aleochara ruficornis GravenHORST, 1802: 91.

Type material examined:

Neotype $\sigma^{\star}$, present designation: Hennenwiesen, Naumburg, 22.4.24, Dr. Maertens / Aleochara ruficornis Gr., det./corr./teste J. Vogel / Neotypus ơ Aleochara ruficornis Gravenhorst, desig. V. Assing 2009 / Aleochara ruficornis Gravenhorst, det. V. Assing 2009 (MNHUB).

\section{Comment:}

According to the original description, Gravenhorst (1802) collected the species only once ("rarissima, semel modo capta") in the environs of the northern German town Braunschweig, but it is unclear if this means that he found only one specimen. The type material was looked for, but not found in the historical collections of the MNHUB (Willers, e-mail 24.VII.2009). The Gravenhorst collection was originally deposited in the "Zoologisches Museum der Universität Breslau" (today Wrocław) and later destroyed (SchüLKe pers. comm.). According to Gravenhorst (1832), the collection contained four specimens of $A$. ruficornis, possibly syntypes. There is no reasonable doubt that they are lost. Since $A$. ruficornis is the type species of Ceranota, it seems advisable to designate a neotype in the interest of the stability of nomenclature. Therefore, the above neotype specimen was selected from the collections of the MNHUB, where numerous other Gravenhorst types are deposited. 


\section{Additional material examined:}

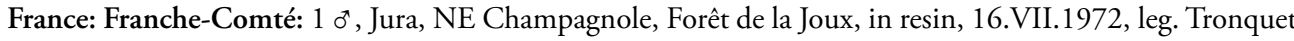
(cTro).

Germany (see also Assing 1994, 2001a): Schleswig-Holstein: 1 ex., Krummsee near Malente, IV.1960, leg. Knappe (NHMW); 1 ex., Eutin, 10.VII.1921 (SDEI); 1 ex., Eutin, 29.IV.1921 (SDEI); 1 ex., Eutin, 18.VII.1916 (SDEI); 1 ex., Eutin, Beutinerholz, 23.V.1910 (SDEI). Saarland: 1 ex., Perl, Nennig env., 8.VI.1996, leg. Renner (cRen). Niedersachsen: 1 ex., Wilhelmshaven, Neuenburger Urwald, beech eclector, 5.VIII.1996, leg. Menke (cAss); 1 ex., Cuxhaven env., Wurster Heide, pitfall, $5 . V I .1987$ (cAss); 1 ex., same data, but 27.VI.1987 (cAss); 1 ex., same data, but 3.VIII.1987 (cAss); 1 ex., Bad Pyrmont env., Thal, limestone beech forest, 11.IV.1987 (cAss); 1 ex., $30 \mathrm{~km} \mathrm{SW} \mathrm{Hannover,} \mathrm{Deister,} \mathrm{near} \mathrm{Nienstedt,} \mathrm{in} \mathrm{excrements,}$ 31.V.1985, leg. Assing (cAss); 1 ex., Bückeburg env., Ahnsen, arable land, pitfall, 14.VII.1985, leg. Sprick (cAss); 1 ex., same data, but 20.VI.1986 (cAss); 1 ex., Lehrte, forest, pitfall, V.1989, leg. Wölkerling (cAss); 1 ex., SE Wolfenbüttel, Öselberg, mesobrometum, pitfall, VII.1998 (cAss); 1 ex., Salzgitter, Ortsteil Gitter, gliderport, pitfall, VI.1999 (cAss); 1 ex., E Schladen, Hedeper, Westerberg, pitfall, V.2001, leg. Schmidt (cAss); 1 ex. [teneral], Hameln env., Ith, near Lauenstein, 300 m, mixed forest, pitfall, 1.V.1990 (cAss); 1 ex., Huntlosen, 28.IV.1902 (SDEI); 1 ex., Huntlosen, 7.VI.1903 (SDEI). Nordrhein-Westfalen: 1 ex., Paderborn, Frankenberg (NHMW); 1 ex., Paderborn, Wewer, Ziegenberg, pitfall, 30.VI.1981, leg. Renner (cRen); 3 exs., Paderborn (MNHUB); 1 ex., Aachen, Walheim, 17.V.1987, leg. Wunderle (cWun); 1 ex., Detmold env., 1889, leg. Dormeyer (MNHUB); 1 ex., Nottuln, 4.VI.1990, leg. Terlutter (cRen); 1 ex., Warburg, Ossendorf, Heinberg, pitfall, 1.VIII.1981, leg. Renner (cRen). Hessen: 1 ex., Kassel, leg. Richl (NHMW); 1 ex., Kassel env., Reinhardtswald, 31.V.1935, leg. Ihssen (MNHUB); 1 ex., Marburg, Cappel, 1.I.1987, leg. Wunderle (cWun); 1 ex., Darmstadt (SDEI); 2 exs. [slightly teneral], Korbach, Diemelsee, Wirminghausen, 14.V.1988, leg. Malten (MNHUB); 1 ex., Vogelsberg, Lauterbach, 410 m, 17.VIII.1991, leg. Frisch (MNHUB). Baden-Württemberg: 1 ex., Blaubeuren/Ulm, Merklingen, dry fallow, 12.V.2007, leg. Renner (cRen). Rheinland-Pfalz: 1 ex., Heinzenberg, Kellenbachtal, 23.IV.1987, leg. Wunderle (cWun); 1 ex., Altenahr, 21.VI.1988, leg. Büchs (cWun); 1 ex., Gau Algesheim, 26.V.1901 (SDEI); 1 ex., Ahrweiler, leg. Fuss (MNHUB). Bayern: 1 ex., München, leg. Harold (SDEI); 1 ex., München, 18.VI.1909, leg. Ihssen (MNHUB); 1 ex., Würzburg, III.1912, leg. Waegner (MNHUB). Mecklenburg-Vorpommern: 1 ex., Wohlenberger Wiek, beach, 5.VI.1983, leg. Hoppe \& Knodel (MNHUB). Sachsen-Anhalt: 2 exs., Halle, Saalkreis, Hohenweide, floodplain forest, VI.1996, leg. Sprick (cAss); 1 ex., Halle, Landkreis Merseburg, Knapendorf, meadow, V.1996, leg. Sprick (cAss); 1 ex., Naumburg env., Rötel, "bei Ameisen", 11.V.1919, leg. Maertens (MNHUB); 1 ex., Naumburg, Hennenwiesen, 22.IV.1924, leg. Maertens (MNHUB); 1 ex., Naumburg, Sperlingsholz, 22.VI.1935 (MNHUB); 1 ex., Dessau, leg. Heidenreich (MNHUB); 5 exs., Aken, leg. Heidenreich (MNHUB). Brandenburg/Berlin: 1 ex., Berlin (MNHUB); 2 exs., Deetz, reed, pitfall, VI.1992, leg. Plötner \& Uhlig (MNHUB). Thüringen: 1 ex., Arnstadt, 28.V.1929, leg. Liebmann (SDEI); 1 ex., same data, but 3.VI.1941 (SDEI); 1 ex., same data, but 6.VII.1923 (SDEI); 1 ex., same data, but 9.VII.1941 (SDEI); 1 ex. [teneral], Hainrode-Hainleite, 26.IV.1916, leg. Petry (MNHUB); 1 ex., Bad Langensalza, Hütscheroda, forest margin, 29.V.2001, leg. Renner (cRen); 1 ex., locality not specified, leg. Kellner (NHMW). Sachsen: 1 ex., Oederan, leg. Cohrs (NHMW); 1 ex., Stollberg, garden, 10.VI.1942, leg. Uhmann (SDEI); 1 ex., Stollberg, 13.IV.1926, leg. Uhmann (SDEI); 1 ex., same data, but 1.VI.1944 (SDEI); 1 ex., same data, but 8.V.1926 (SDEI); 1 ex., Stollberg, V.1916 (SDEI); 1 ex., Sächsische Schweiz, Schandau, 23.V.1934 (MNHUB); 1 ex., Auerbach, 22.VII.1971, leg. Kaufmann (MNHUB); 1 ex., same data, but 10.VII.1971 (MNHUB); 1 ex. [teneral], same data, but 21.IV.1971 (MNHUB); 1 ex., Auerbach, 26.VIII.1971 (MNHUB); 1 ex., Altenburg env., Forst Leina, 24.VII.1984, leg. Naumann (cRen); 2 exs., "Saxonia", leg. Märkel, etc. (SDEI). Locality not specified: 4 exs., "Germania" (MNHUB).

Switzerland: 1 ex., Schaffhausen (SDEI).

Austria: Steiermark: 1 ex., Selztal (NHMW); 1 ex., Graz env. (NHMW); 1 ex., Graz, leg. Penecke (NHMW); 2 exs., Rottenmanner Tauern (NHMW). Kärnten: 1 ex., Klagenfurt, leg. Klimsch (NHMW); 1 ex., Sachsenburg (NHMW). Niederösterreich: 1 ex., Kranichberg, 1887, leg. Ganglbauer (NHMW); 2 exs., Semmering (NHMW); 1 ex., Stillfried, 20.V.1909, leg. Holdhaus (NHMW); 1 ex., Hütteldorf, leg. Moczarski (NHMW); 1 ex., Purgstall, flood debris, 25.IV.1957, leg. Ressl (NHMW); 1 ex., Purgstall, 
27.III.1955 (NHMW); 2 exs., Wien env., leg. Hille, Schade (NHMW); 1 ex., Wienerwald, Mauerbach, 17.V.1951, leg. Wettstein (NHMW); 1 ex., Hüttendorf near Wien (NHMW); 1 ex., Bisamberg near Wien, 30.III.1920, leg. Moczarski (NHMW); 1 ex., Hermannskogel near Wien, leg. Scheerpeltz (NHMW); 1 ex., Vorder-Hainbach near Wien, V.1943, leg. Mandl (NHMW). Burgenland: 1 ex., Neusiedlersee, Andau, 2.IX.1988 (NHMW). Locality not specified: 1 ex., "Austria" (MNHUB).

Italy: Abruzzo: 1 ex., Gran Sasso, Prati di Tivo (TE), 1450 m, 2.VI.2001, leg. Angelini (cAss). Lazio: 1 ex., Roma, locality illegible, leg. Fiori (MNHUB). Basilicata: 2 exs., Mte. Pollino, beech forest, pitfall, 25.VII.1977, leg. Brandmayr (cAss); 1 ex., Pollino, Piano Ruggio (PZ), 1500 m, 11.VI.1977, leg. Montemurro (cAss); 1 ex., Piano Ruggio, 1510-1590 m, 22.VI.1985, leg. Angelini (cWun).

Czech Republic: 2 exs., Praha, leg. Skalitzky (NHMW); 2 exs., Praha env. (HNHM, NHMW); 1 ex., "Reonie" (?) near Praha (NHMW); 1 ex., "Strah. Gt.", Praha (NHMW); 1 ex., Liberec ["Reichenberg"] (NHMW); 1 ex., Mladá Boleslav ["Jungbunzlau"], leg. Skalitzky (NHMW); 1 ex., Moravia, Brod, leg. Wanka (NHMW); 2 exs., Paskov, leg. Reitter (HNHM).

Slovakia: 1 ex., Trenčin (MNHUB); 1 ex., Trenč́n, Inovec [4840N, 1800E], leg. Cepelák (MNHUB); 1 ex., Tatry, Lom, 2300 m, 7.VII.1961, leg. Endrődy (HNHM); 1 ex., Muranska planina, Suché doly, 4 km W Tisovec, 4841 'N; 1953'E, 630 m, vertical cave, 15.VI.2009, leg. Makranczy (HNHM); 1 ex., Lubochňa ["Fenyőháza"], Gombás, 19.VII.1909, leg. leg. Gurányi (HNHM);.

Poland: 1 ex., Legnica (SDEI); 1 ex., Bytom Odrzański ["Beuthen"], leg. Nowotny (MNHUB); 1 ex., Bielinek ["Bellinchen"], VIII.1929 (MNHUB); 2 exs., "Silesia" (SDEI); 1 ex., "Schlesien" (SDEI).

Hungary: 1 ex., N Lake Balaton, Nagyvázsony (NHMW); 1 ex., Aggtelek National Park, Aggtelek, Ménes-völgy, 9.V.1987, leg. Podlussány (HNHM); 1 ex., Aggtelek National Park, Aggtelek, 10.V.1987, leg. Podlussány (HNHM); 4 exs., Aggtelek National Park, Aggttelek, Patkós-oldal, 2.V.1987, leg. Ádám (HNHM); 1 ex., Aggtelek National Park, Szögliget, Patkós-völgy, beech forest, V-VIII.1987, leg. Ádám (HNHM); 1 ex., Budapest, 11.VII.1918 (HNHM); 1 ex., Budapest, 19.VII.1913 (HNHM); 1 ex., Budapest, 26.V.1916 (HNHM); 2 exs., Budapest, leg. Mihok (HNHM); 1 ex., Győr-Moson-Sopron megye, Ásványráró, 6.VI.1995, leg. Szél (HNHM); 2 exs., same data, but 23.VI.1995 (HNHM); 1 ex., Győr-Moson-Sopron megye, Ásványráró, 28.V.1991, leg. Ádám (HNHM); 2 exs., Győr-Moson-Sopron megye, $3 \mathrm{~km}$ E Ásványráró, $47^{\circ} 50^{\prime} \mathrm{N}, 17^{\circ} 32^{\prime} \mathrm{E}, 110 \mathrm{~m}$, gallery forest, pitfall trap, 27.V.-11.VI.2008, leg. Makranczy (HNHM); 1 ex., same data, but V.2008 (HNHM); 2 exs., same data, but VI.2008 (HNHM); 2 exs., Győr-Moson-Sopron megye, Püski, 2.V.-23.VI.1993, leg. Merkl (HNHM); 1 ex., Győr-MosonSopron megye, Hédervár, 6.VI.1993, leg. Merkl (HNHM); 1 ex., Győr-Moson-Sopron megye, Osli, Tölösierdő, car-net, 19.VI.2000, leg. Merkl (HNHM); 1 ex., Győr-Moson-Sopron megye, 3 km E Dunaremete, $47^{\circ} 52^{\prime} \mathrm{N}, 17^{\circ} 29^{\prime} \mathrm{E}, 110 \mathrm{~m}$, gallery forest, pitfall trap, VI.2008, leg. Makranczy (HNHM); 2 exs., same data, but V.2008 (HNHM); 1 ex., same data, but 27.V.-11.VI.2008 (HNHM); 1 ex., Pest m., Tahitótfalu, Ábrahám-bükk, 11.V.1986, leg. Merkl (HNHM); 2 exs., Baranya m., Bátaapáti, 10.VII.2002, leg. Szél (HNHM); 1 ex., Vas-Megye, 1890 (HNHM); 2 exs., Mátra (HNHM).

Slovenia: 2 exs., Maribor (NHMW); 1 ex., Ig, V.1978, leg. Frank (cAss).

Slovenian or Italian territory: 1 ex., Gorizia, leg. Strupi (NHMW).

Romania: 1 ex., Bukarest (NHMW).

Croatia: 1 ex., Učka ["Mte. Maggiore"; 4515N, 14¹2E], leg. Breit (NHMW).

Bosnia-Herzegovina: 1 ex., Šiša planina, 1892, leg. Beck (NHMW); 1 ex., Maklen pass, 1902, leg. Leonhard (SDEI).

Locality not specified or illegible: 10 exs. (MNHUB, NHMW, SDEI); 1 ex., IV.1948 (MNHUB); 3 exs., "Sartorius 1876" (NHMW).

\section{Diagnosis:}

Body length 4.5-10.0 mm. Coloration variable: head blackish-brown to blackish; pronotum and elytra reddish, with the pronotum in the middle mostly more or less extensively and more or less distinctly infuscate, sometimes completely reddish or almost completely dark, with the pronotal margins narrowly reddish; abdomen with tergites III-V and VII reddish, anteriorly more or less extensively blackish, often with anterior blackish spot, occasionally with most of tergal surface 
blackish, except for the reddish posterior margins; tergite VI blackish, usually with broadly reddish margins; segments VIII-X reddish.

Ante-clypeus broadly semi-membranous anteriorly. Pronotum conspicuously large, 1.28-1.36 times as wide as long and 1.5-1.9 times as wide as head, larger and relatively broader in larger than in smaller specimens; posterior angles completely rounded, not marked. Anterior impressions of tergites III-VI with rather dense and moderately coarse punctation.

$\sigma^{*}$ : tergite III at posterior margin with median tubercle or process of very variable shape: either spine-like and apically acute (usually in smaller males), or shaped like a transverse ridge with convex or even concave apical margin (large to very large males); tergite IV with very weakly to distinctly elevated, smooth, circular, apically smoothly rounded, very rarely acute (very large males) median tubercle; tergite VII at posterior margin with - usually weakly delimited and rather weakly elevated - transverse median ridge, this ridge at both ends often with small, more or less distinctly visible tubercles; sternite IV and V without impressions and without distinctly microsculptured patches, but with transverse clusters of moderately dense long pubescence (Fig. 76-77); median lobe of aedeagus as in Figs 1-3; basal part distinctly produced ventrally; ventral process rather broad (blade-like) and subapically rounded (not weakly angled) in ventral view.

+ : tergites III and IV with or without very small median tubercles; tergite VII usually unmodified; spermatheca of relatively compact shape (Fig. 53).

\section{Distribution and bionomics:}

Aleochara ruficornis is the least rare and one of the most widespread species of the subgenus. Its distribution is apparently of the Adriato-Mediterranean type and ranges from BosniaHerzegovina and southern Italy to Great Britain, southern Fennoscandia, and Ukraine (Horion 1967, Smetana 2004; material examined). For a selection of literature records see Brenner (1993, 1996), Dvořák (1967), Erbeling \& Drees (1992), Eyre et al. (2000), Grundmann \& Erbeling (1992), Hansen (1995), Hansen et al. (1994, 1995), Havelka (1964), Janák (1993), Junker (2001), Кoch (1968), Kocian (1993), Köhler (1996), Köhler \& Stumpf (1992), Likovský (1968), Linke (1907), Lohse (1967), Luigioni (1929), MajZlan \& Jászay (1997), Molenda (1996), Renner (2001), Schaffrath (1999), Schatz et al. (2003), Schmaus (1969), Scholze \& Jung (1994), Segers (1986), Smetana (1954), Uhlig \& Vogel (1981), Vogel (1982), Vogel \& Dunger (1980), Welch (1997), and Zerche (1980). Based on Smetana (2004), the specimens listed above from Croatia, Romania, and Spain represent new country records.

The species has been collected in forested and unforested biotopes, particularly grassland, in various kinds of decaying matter (compost, excrements, etc.), on banks of rivers and streams, as well as in clay and sand pits; in Central Europe it is regularly found on calcareous grassland, primarily with pitfall traps (Assing 1994, 2001a, Brenner 1993, 1996, Erbeling \& Drees 1992, Feldmann \& Lückmann 1998, Kunze \& Kache 1998, Horion 1967, Vogel \& Dunger 1991). According to BicKHARDT (1907), on one occasion as many as 18 specimens were collected from badger burrows. Horion (1967) reports several observations of flying specimens.

Based on pitfall trap studies, the species is epigeically active from April through August, with a maximum in May and June. Teneral adults were observed in April and May. The ovaries of dissected females collected in May and June contained mature eggs, suggesting that oviposition takes place in this period. Dissections of the thorax revealed that a considerable proportion of the specimens from the examined populations in northern Germany lack functioning flight muscles (Assing 1994). 
Aleochara (Ceranota) erythroptera Gravenhorst, 1806 (Figs 4-5, 54, Map 1)

Aleochara erythroptera GravenHORST, 1806: $158 \mathrm{f}$.

\section{Type material examined:}

Neotype $0^{\star}$, present designation: München 15.5.10 / erithroptera [sic] / Aleochara erythroptera, teste J. Vogel / Neotypus ơ Aleochara erythroptera Gravenhorst, desig. V. Assing 2009 / Aleochara erythroptera Gravenhorst, det. V. Assing 2009 (MNHUB).

\section{Comment:}

The original description is based on an unspecified number of syntypes from Nürnberg ("Norimbergae") collected by Sturm (Gravenhorst 1806). The type material looked for, but not found in the historical collections of the MNHUB (Willers, e-mail 24.VII.2009). It was not deposited in the "Zoologisches Museum der Universität Breslau" either (Gravenhorst 1832). According to Horn et al. (1990), the Sturm collection is deposited in the Zoologische Staatsammlung München. The type material was looked for, but not found by the curator in charge (BALKe, e-mail 7 September 2009), suggesting that it is lost. Aleochara erythroptera is one of the most widespread species of the subgenus and has often been misidentified or misinterpreted. Therefore, in the interest of the stability of nomenclature, the above male from the collections of the MNHUB is designated as the neotype.

For a detailed redescription, including measurements, comparative notes, and illustrations, as well as additional comments see Assing (2007). The aedeagus and the spermatheca are illustrated in Figs 4-5, 54.

\section{Additional material examined:}

Germany (see also Assing 1994): Nordrhein-Westfalen: 1 ex., Bielefeld, Augustdorf, car-net, 20.VI.1995, leg. Renner (cRen). Niedersachsen: 1 ex., Neustadt am Rübenberge, Himmelreich, window trap, 6.V.1990, leg. Schmidt (cAss); 1 ex., same data, but 3.VI.1990 (cAss); 2 exs., same data, but 15.IV.1991 (cAss); 1 ex., Lehrte, forest, pitfall, 1.-15.VII.1989, leg. Wölkerling (cAss); 1 ex., Lehrte, deciduous forest, pitfall, 16.V.1986, leg. Wölkerling (cAss); 1 ex., Hildesheim, Mastberg, 20.V.-2.VI.2002, leg. Schmidt (cShm). Brandenburg/Berlin: 2 exs., Berlin, leg. Schüppel (MNHUB); 1 ex., Tiefwerder, on sap of lime tree (MNHUB). Sachsen-Anhalt: 1 ex., Thale/Harz, Waldkater, at window, 3.VI.1952, leg. Dorn (MNHUB); 1 ex., same data, but 13.VI.1952 (MNHUB); 1 ex., same data, but 3.VIII.1954 (MNHUB); 1 ex., same data, but 25.VI.1955 (MNHUB). Sachsen: 4 exs., locality not specified, leg. Bayer, Märkel, etc. (NHMW, SDEI). Baden-Württemberg: 1 ex., Villingen (NHMW); 1 ex., "Schwarzwald", leg. Mayer (NHMW). Bayern: 1 ex., Günzburg, leg. Oberndorfer (NHMW); 1 ex., München, 5.V.1910, leg. Ihssen (MNHUB); 2 exs., 15.V.1910 (MNHUB); 1 ex., München (NHMW). Locality not specified: 1 ex., "Germ." (SDEI).

Austria: Oberösterreich: 1 ex., Grünberg, 1909, leg. Bernhauer (SDEI). Niederösterreich/Wien: 2 exs., Wechselgebirge, 1889, leg. Ganglbauer (NHMW); 1 ex., Wechsel, leg. Mader (NHMW); 2 exs., Perchtoldsdorf, burrows of Spermophilus, leg. Scheerpeltz (NHMW); 1 ex., Perchtoldsdorfer Heide, nest of Formica pratensis, 27.IV.1934, leg. Moczarski (NHMW); 1 ex., Hainburg, 7.V.1905, leg. Pinker (NHMW); 1 ex., Kritzendorf, leg. Hicker (NHMW); 1 ex., Wien env., leg. Lackner (NHMW); 1 ex., Wien env. (NHMW); 1 ex., Wien, leg. Scriba (SDEI); 1 ex., Wienerwald, leg. Breit (NHMW); 1 ex., Wien, Rekawinkel, leg. Scheerpeltz (NHMW); 1 ex., Wien, Rodaun (NHMW); 1 ex., Haschendorf near Wiener Neustadt, pitfall, III.1968, leg. Malicky (cAss). Steiermark: 1 ex., Hochschwab (NHMW); 1 ex., Graz env. (NHMW); 1 ex., Turnau (NHMW); 1 ex., Turnau, Steinwiesen, 950 m, 14.VI.1934, leg. Moczarski (NHMW). Kärnten: 2 exs., Villach (NHMW); 1 ex., Eisenkappel, 13.VI.1965 (NHMW). Burgenland: 1 ex., Leithagebirge, 8.V.1992, leg. Renner (cRen); 2 exs., Neusiedlersee (NHMW).

Italy: Piemonte: 1 ex., Crissolo, 3.VII.1907, leg. Pinker (NHMW); 4 exs., Crissolo (NHMW, cAss); 1 ex., Valle di Loccana, 3 km W Ceresole Reale, 1400 m, Larix forest, 30.V.2004, leg. Hetzel (cFel); 1 ex., Valle 
Stura (CN), SW Vinadio, 1400 m, 7.V.1997, leg. Assing (cAss). Valle d'Aosta: 1 ex., NE Aosta, Ollomont, car-net, 23.VII.1998, leg. Ziegler (cAss). Veneto: 1 ex., Belluno, leg. Ravasini (MCSNT). Emilia-Romagna: 1 ex., Modena, leg. Fiori (NHMW). Puglia: 1 ex., Gargano, Mte. S. Angelo, leg. Holdhaus (NHMW). Lazio: 1 ex., Val Salto, VII.1909, leg. Pinker (NHMW).

Slovakia: 1 ex., Bratislava, leg. Weber (NHMW); 1 ex., Rimavska Sobota ["Rimaszombat"], leg. Bolkay (HNHM).

Czech Republic: 1 ex., Praha, "Kuchelbad" (?), 8.IV.1885 (NHMW); 1 ex., Praha, leg. Skalitzky (NHMW); 1 ex., Brandýs n. L., leg. Skalitzky (NHMW).

Poland: 1 ex., Kłodzko [Glatz] (SDEI); 1 ex., Legnica (SDEI); 1 ex., "Schlesien" (SDEI).

Slovenia: 1 ex., Crna prst, VI.1902, leg. Pinker (NHMW); 1 ex., "Ternowanerwald", 1000 m (NHMW).

Hungary: 1 ex., Bugac, Kiskunság National Park, grassland, pitfall, 16.IV.1982, leg. Gallé (cAss); 1 ex., same data, but 24.IV.1986 (cAss); 4 exs., Kalocsa, leg. Speiser (HNHM, NHMW); 1 ex., Neusiedlersee, leg. Breit (NHMW); 1 ex., Nyírség, Bátorligeti-láp, 25.VI.-3.VII.1949, leg. Kaszab \& Székessy (HNHM); 1 ex., same data, but VI.1949 (HNHM); 1 ex., Hortobágy National Park, Újszentmargita, 22.VI.1975, leg. Hámori (HNHM); 1 ex., Kiskunfélegyháza, 17.VI.1942, leg. Móczár (HNHM); 1 ex., Szigetszentmiklós, 1912, leg. Biró (HNHM); 1 ex., Bükk National Park, Szarvaskő, Tardos-hegy, 400 m, 4.V.1981, leg. Hámori (HNHM); 1 ex., Bükk National Park, Miskolc, 650 m, beech forest, 7.V.1981, leg. Ádám \& Hámori (HNHM); 1 ex., Bükk National Park, Cserépfalu, 250 m, oak and hornbeam forest, 15.V.1985, leg. Merkl (HNHM); 2 exs., Szabolcs-Szatmár-Bereg megye, Bátorliget, Bátorligeti-láp, IV.1989, leg. Dely (HNHM); 1 ex., Bösztörpuszta, 5.V.2005, leg. Kovács (HNHM); 1 ex., Budapest, leg. Gurányi (HNHM); 1 ex., Budapest, V.1991, leg. Kaszab (HNHM); 2 exs., Budapest (HNHM); 1 ex., Budapest, Káposztásmegyer, 100 m, 1.V.1986, leg. Merkl (HNHM); 1 ex., Budapest, Vadaskert, 10.V.1936, leg. Csiki (HNHM); 2 exs., Pest megye, Bugyi, Felsővany, car-net, 3.IV.2005, leg. Merkl (HNHM); 1 ex., Pest megye, Szigetbecse, car-net, 26.III.2000, leg. Merkl (HNHM); 1 ex., Pest megye, Halásztelek, 17.III.1990, leg. Merkl (cAss); 1 ex., Pest m., Budaörs, Törökugrató, 24.IV.2005, leg. Merkl (HNHM); 2 exs., Aggteleki National Park, Jósvafo, Nagy-oldal, 25.IV.1990, leg. Merkl (HNHM); 1 ex., Aggteleki National Park, Jósvafó, Szelce-völgy, 25.IV.1990, leg. Merkl (HNHM); 2 exs., Békés megye, Battonya, Tompapuszta, 15.IV.1998, leg. Podlussány (HNHM); 1 ex., Tolna megye, Bátaapáti, Üveghutai-völgy, car-net, 17.V.2006, leg. Merkl et al. (HNHM); 1 ex., Veszprém megye, Lovas, Malom-völgy, 22.IV.1993, leg. Merkl (HNHM); 1 ex., Vértes h., Csákvár, 16.V.1961 (HNHM); 1 ex., Bártfa, leg. Mihalovics (HNHM); 1 ex., Marostorda megye, Gödemesterháza, 750 m, VIII.1943, leg. Éhik \& Loksa (HNHM); 1 ex., Szeged, leg. Stiller (HNHM); 1 ex., Berhida, IV.1955, leg. Lenci (HNHM); 2 exs., Csillebérc, 1 8.V.1910 (HNHM); 1 ex., Mátra (HNHM); 2 exs., Vas megye, Kenyeri, 27.IV.-2.V.2005, leg. Dankovics \& Vig (HNHM).

Romania: 2 exs., Braşov, leg. Breit, Deubel (NHMW); 1 ex., "Rosenauer G." [ca. 4526' N, 252 25'E], leg. Deubel (NHMW); 1 ex., "Transsylvan.", leg. Hopffgarten (NHMW); 2 exs., S Braşov, Schuler, leg. Deubel, Ganglbauer (NHMW); 1 ex., Braşov, "Kapellenberg", leg. Deubel (NHMW); 1 ex., Timiş ["Lugos"; $\left.45^{\circ} 41^{\prime} \mathrm{N}, 21^{\circ} 54^{\prime} \mathrm{E}\right]$, leg. Breit (NHMW); 1 ex., Băile Herculane, 14.V.1931 (MNHUB); 1 ex., Azuga (HNHM); 1 ex., Marostorda megye, Stânceni, ["Gödemester-háza"], 750 m, VIII.1943, leg. Éhik \& Loksa (HNHM).

Croatia: 1 ex., Učka ["Mte. Maggiore"; 4515N, 14¹2E], leg. Breit (NHMW).

Bosnia-Herzegovina: 1 ex., Maklen pass, 1902, leg. Leonhard (SDEI); 1 ex., Bjelašnica planina, peak region, leg Leonhard (SDEI); 1 ex., Travnik (HNHM).

Montenegro: 1 ex., Radostak [ $\left.42^{\circ} 30^{\prime} \mathrm{N}, 18^{\circ} 34^{\prime} \mathrm{E}\right]$ (NHMW).

Bulgaria: 2 exs., Simeonovgrad ["Sejmen"; 4202'N, 2550'E], Marica river, 21.III.1909, leg. Rambousek (NHMW, SDEI); 1 ex., Rhodopes, Persenk [41 $\left.{ }^{\circ} 50^{\prime} \mathrm{N}, 24^{\circ} 34^{\prime} \mathrm{E}\right]$, leg. Breit (NHMW); 1 ex., Borovets

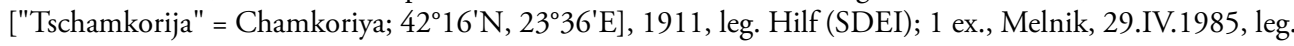
Wrase (MNHUB).

Greece, mainland [see also Assing \& Wunderle 2001]: 1 ex., "Olymp" (NHMW). Pelopónnisos: 1 ex., Feneos, $37^{\circ} 55^{\prime} \mathrm{N}, 22^{\circ} 16^{\prime} \mathrm{E}$, Abies cephalonica forest, IV.-VI.2006, leg. Miksch (cSch); 1 ex., Feneos, $37^{\circ} 55^{\prime} \mathrm{N}$, $22^{\circ} 18^{\prime}$ E, oak forest, IV.-VI.2006, leg. Miksch (cSch). Kérkira: 1 ex., Mt. Deka, leg. Woerz (NHMW).

Turkey: see Assing (2007). 
Ukraine: 1 ex., Odessa, bank of Kuyalnik liman, 31.III.2002, leg. Gontarenko (cAss); 1 ex., Crimea, Bakhchisarai district, Kuibyshevo, Belbel river bank, 20.VI.2002, leg. Guseva (cTro).

Russia: 1 ex., Tulskaja obl., Galitsa env., NW Jefremov, 5309' N, 3759'E, 24.IV.1986, leg. Pütz (cAss); 1 , Sarepta (SDEI); 1 ex., Rostov province, Sal'sk district, Ginant [Gigant?], steppe, pitfall, IV-VI.2002, leg. Zverev (cTro).

Locality not specified, not identified, ambiguous, or illegible: 8 exs. (HNHM, NHMW, SDEI); 1 ex., "Süd-Ungarn", leg. Merkl (NHMW); 1 ex., "Kahr 38" (NHMW); 1 ex., "Sartorius 1876" (NHMW); 1 ex., "Neumarkt", leg. Scriba (SDEI).

\section{Distribution and bionomics:}

Aleochara erythroptera apparently has a Ponto-Mediterranean distribution and is widespread in southern and central Europe. It has not been recorded from North Africa, Great Britain, and Fennoscandia (Map 1). The above specimens from Slovenia, Bulgaria, and Ukraine represent new country records. For a selection of literature records see Dvořák (1967), IENişTEa \& Fabritius (1982), Ihssen (1935), Janák (1993), Косh (1968), Kopetz \& Weigel (2006), Likovskí (1968), Luigioni (1929), Müller (1926), Peez \& Kahlen (1977), Renner (2001), Schatz (2006), Staniec $(1992,1996)$, and Wörndle (1950). As can be inferred from the revised distribution, the record from southern Spain (Gamarra \& Outerelo 2005, Outerelo 1980) is probably based on a confusion with $A$. diversicollis or $A$. hydrocephala.

The species has been collected in forests (fir, larch, oak, etc.) and unforested biotopes (subalpine habitats, xerothermous grassland), in leaf litter, grass roots, near snow, moss, hollow trees, excrements, flood debris, as well as in burrows of mammals (Talpa, Spermophilus) and nests of wood ants at altitudes of up to 2200 m (Assing 1994, 2007, Ermisch \& LANGer 1933, Horion 1967; material examined). The true reproduction habitat is unknown.

In northern Germany, at the northern distribution limit, epigeic activity was recorded with pitfall traps from May through August (Assing 1994). Flying specimens have been observed from March through August (Horion 1967, Wörndle 1950; material examined).

\section{Aleochara (Ceranota) ganglbaueri BERnHAUER, 1901 (Figs 6-7, 55, 78-79)}

Aleochara ganglbaueri BeRNHAUER, 1901: $493 \mathrm{f}$.

Aleochara (Ceranota) pacholei Bernhauer, 1928: 23; synonymy confirmed.

\section{Type material examined:}

A. ganglbaueri: Holotype $o^{\star}$ [dissected prior to present study]: ${ }^{\star} /$ Ganglb. 98, Rolle-Pass / SüdTirol / Ganglbaueri Bernh. Type / Typus / Aleochara ganglbaueri det. J. Vogel 1989 / Holotypus Aleochara ganglbaueri Bernhauer rev. V. Assing 2007 (NHMW).

A. pacholei: Holotype $\sigma^{\star}$ [dissected prior to present study]: Triglav-Gebiet, Pachole, Wien / n. sp. Flg. glänzend / Aleochara Pachole [sic] Brh. Typus unic. / Chicago NHMus M.Bernhauer Collection / Holotypus Aleochara pacholei Bernhauer rev. V. Assing 2007 / Aleochara ganglbaueri Bernhauer det. V. Assing 2007 (FMNH).

\section{Comment:}

The original description of $A$. ganglbaueri is explicitly based on a single holotype male ("in einem Exemplare ( $\left.\sigma^{\top}\right) "$ ) collected "am Rollepass in Südtirol" (Bernhauer 1901). Similarly, the description of $A$. pacholei is based on a single male specimen ("in einem männlichen Stück") from the Triglav range in Slovenia (Bernhauer 1928). The previously established synonymy of $A$. pacholei with $A$. ganglbaueri is confirmed. 
Additional material examined:

Germany: Bayern: 2 exs., Garmisch-Partenkirchen, 9.VI.1934, leg. Ihssen (MNHUB); 1 ex., Farchant, 800 m, 20.V.1972, leg. Schmidt (cRen).

Austria: Tirol: 1 ex., Stanzach, Lech valley, 900-1300 m, car-net, 25.V.1995, leg. Assing (cAss); 1 ex., Stanzach, Namloser valley, car-net, 24.V.1995, leg. Renner (cRen); 1 ex., Innsbruck env., leg. Strupi (NHMW); 1 ex., Halltal, 28.V.1905, leg. Wörndle (NHMW). Osttirol: 2 exs., Lienz (NHMW). Kärnten: 1 ex., Zell, Hudajamagraben, 26.VI.-4.VII.1987, leg. Siede \& Wunderle (cWun).

Italy: Trentino-Alto Adige: 1 ex., Racines (BZ), Ridanna ["Ridnaun"], 25.VIII.1906 (MNHUB); 1 ex., Vallarsa, leg. Strupi (NHMW). Venezia Giulia: 1 ex., Giais, 25.VII.1950, leg. Busulini (NHMW). Veneto or Friuli-Venezia Giulia: 1 ex., Bosco del Cansiglio, Val Seraie, 2.VI.1956, leg. Agazzi (NHMW); 1 ex., Mte. Cavallo (NHMW).

Slovenia: 1 ex., Crna prst, 1902, leg. Pinker (NHMW).

\section{Diagnosis:}

Highly similar to A. erythroptera. On average larger, body length 4.5-9.0 mm; habitus rather broad. Coloration: head blackish-brown to blackish; pronotum brown to blackish-brown with reddish margins; elytra reddish; abdomen black, with the posterior margins of segments III-VI, the posterior third of segment VII, and segments VIII-X reddish; occasionally the reddish coloration of tergites III-VI may be more extensive, leaving only the middle of the tergites blackish.

Head with distinct, pronotum with shallower, but noticeable microreticulation. Clypeus anteriorly rather narrowly semi-membranous. Pronotum relatively large, 1.25-1.35 times as wide as long and 1.60-1.75 times as wide as head; posterior angles weakly marked or obsolete. Anterior impressions of tergites III-VI with very sparse and fine punctation; posterior portions of tergites III-V with rather sparse and fine punctation, that of tergite VI often with somewhat denser punctation (at least in 9 ); tergite VII in the middle in moderately large to large specimens usually with rather dense punctation (particularly in $\sigma^{x}$ ).

$0^{*}$ : tergite III with weakly erect, longitudinal, and apically obtusely keeled to obtusely pointed median tubercle; tergite IV (in large $0^{\top}$ ) with very small median tubercle; tergite VII at posterior margin with transverse median ridge, this ridge somewhat depressed in the middle, on either side of this depression with smoothly granulose apex; sternites IV and V without impressions, but with large transverse patches with pronounced microsculpture and with dense long pubescence (Figs 78-79); median lobe of aedeagus approximately $0.75-0.80 \mathrm{~mm}$ long; ventral process almost straight in lateral view and of broadly triangular shape in ventral view (Figs 6-7).

+ : tergite III usually without, rarely with median tubercle; tergites IV and VII unmodified; spermatheca rather large (Fig. 55).

\section{Distribution and bionomics:}

The known distribution of $A$. ganglbaueri is confined to the Alps, with the vast majority of records from the eastern Alps, westwards to the Bavarian Alps, Tirol, Trentino-Alto Adige and western Veneto (Heiss 1971, Horion 1967, Luigioni (1929), Wörndle 1950; material examined). LikovskÝ (1982) reported the species also from the Western Alps (Switzerland: Vaud). As in other Ceranota species, the circumstances of collection are diverse and not conclusive regarding the true reproduction habitat. The altitudes range from approximately $1000 \mathrm{~m}$ to $1700 \mathrm{~m}$ (HorION 1967, WörndLE 1950; material examined).

The species has been found in summer, from the end of May through August (Horion 1967; material examined). Two specimens were collected on the wing (car-net) in May. 
Aleochara (Ceranota) bituberculata BERNHAUER, 1900 (Figs 8-9, 163-170)

Aleochara (Ceranota) bituberculata Bernhauer, 1900: $48 \mathrm{f}$.

\section{Type material examined:}

Holotype $0^{\star}$ : Asia minor, Sultan Dagh, v. Bodemeyer / bituberculata Brnh. ded. v. Bodemeyer / Type o / Chicago NHMus M.Bernhauer Coll. / Holotypus ơ Aleochara bituberculata Bernhauer rev. V. Assing 2006 (FMNH).

\section{Additional material examined:}

Turkey: Istanbul: 1 ơ $^{\star}$, Alem Dağı (HNHM). Bolu: 3 exs., Abant Dağı, 1400-1550 m, V.1967, leg. Fagel (IRSNB). Sinop: 1 ㅇ , ca. $35 \mathrm{~km}$ SSW Sinop, 41 $43^{\circ} \mathrm{N}, 34^{\circ} 55^{\prime} \mathrm{E}, 660 \mathrm{~m}$, oak forest, sifted, 29.III.2009, leg. Wunderle (cAss).

\section{Comment:}

The original description is explicitly based on a single specimen ("ein Stück") from the "Sultan Dagh in Kleinasien" (Bernhauer 1900).

Bernhauer (1900) originally described $A$. bituberculata as a distinct species, but subsequently considered it a variety of $A$. erythroptera Gravenhorst (Bernhauer 1901). While Fagel (1968) attributed it the status of a distinct species again, LikovskÝ (1973) confirmed the identity of A. bituberculata with $A$. erythroptera based on an examination of the aedeagus. However, when examining the aedeagus, he did not even remove the parameres, so that a proper assessment of its morphology was impossible. Although the taxonomic status of $A$. bituberculata does not seem to have been addressed since then, SMETANA (2004) again treats it as a valid species.

\section{Diagnosis:}

Highly similar to A. erythroptera and also highly variable. Habitus as in Fig. 163. Body length 5.0$8.2 \mathrm{~mm}$. Coloration variable: head blackish; pronotum reddish to blackish; elytra bright reddish; abdomen dark-brown to blackish, with the posterior margins of segments III-VI more or less narrowly, the posterior margin of segment VII broadly, and the apex (segments VIII-X) reddish; legs reddish; antennae reddish to dark-brown, with the basal three antennomeres reddish-yellow to reddish.

Head approximately as wide as long; punctation fine and rather sparse; interstices with or without very shallow microsculpture. Eyes slightly longer than postocular region in dorsal view (Figs 164165). Anterior membranous portion of clypeus moderately broad. Antennae with weakly transverse preapical antennomeres.

Pronotum 1.20-1.35 times as wide as long and 1.45-1.70 times as wide as head; punctation fine and rather dense; interstices without distinct microsculpture (Figs 164-165).

Elytra $0.80-0.85$ times as long as pronotum; punctation dense, coarser than that of pronotum (Figs 164-165).

Abdomen, including anterior impressions of tergites III-VI, with moderately dense and moderately coarse punctation; interstices without distinct microsculpture and glossy (Fig. 166).

$\sigma^{\text {t }}$ : tergite III with weakly erect, subcircular to weakly oblong median tubercle; tergite VII with pair of tubercles at posterior margin (Fig. 166); sternites IV and V with distinctly delimited, somewhat impressed, transversely oval patches with distinct microsculpture and very dense long pubescence; median lobe of aedeagus $0.70-0.88 \mathrm{~mm}$ long, ventral process broad in ventral view; internal sac with massive apical internal structures (Figs 8-9, 167-169).

ㅇ: tergite III with small median tubercle near posterior margin; tergite VII unmodified; spermathecal capsule with large distal and short proximal portion (Fig. 170). 


\section{Comparative notes:}

Aleochara bituberculata is reliably distinguished from the similar A. erythroptera only by the larger aedeagus, with a shorter and broader ventral process, and with more massive apical internal structures, as well as by the shape of the spermatheca. For additional illustrations see Assing (2007).

\section{Distribution and bionomics:}

The species has become known only from four localities in northwestern, northern, and southwestern Turkey. The specimens from Sinop and Bolu were sifted at altitudes of 660 and 1400 $1550 \mathrm{~m}$ in March and May.

Aleochara (Ceranota) diversicollis FAUVEL, 1900 (Figs 10-12, 56, 80-81, 104-107, Map 2)

Aleochara (Ceranota) diversicollis FAUveL, 1900: $246 \mathrm{f}$.

\section{Type material examined:}

Lectotype $\sigma^{\star}$, present designation: Le Vernet [remainder not clearly legible] / $\sigma^{\star} /$ Coll. R. I. Sc. N. B. / Lectotypus ơ Aleochara diversicollis Fauvel, desig. V. Assing 2009 (IRSNB). Paralectotype ㅇ [head and pronotum missing]: ㅇ / St. Martin de Lantosque, août / Coll. R. I. Sc. N. B. (IRSNB).

\section{Comment:}

The original description is based on two syntypes, a male and a female, from "Le Vernet (de Germiny); Saint-Lantosque, août (Linder)" (FAuvel 1900). Both syntypes were located in the Fauvel collection. The male is designated as the lectotype.

Additional material examined:

Spain: $1 \sigma^{\star}$, Murcia, Jumilla, Sierra del Carche, 23.II-22.III.2008, leg. Lencina \& Gallego (cAss). Locality not specified: 2 exs., "Hispania", leg. Bauthin, v. Heyden (NHMW, SDEI).

Evidently mislabelled: $1 \sigma^{\star}$, "Paskau, Reitter" (HNHM).

\section{Redescription:}

Body length 4.8-7.5 mm. Coloration: head blackish; pronotum dark-brown with paler margins to uniformly blackish; abdomen dark-brown to blackish, except for the reddish posterior margins of segments III-VII and the apex (segments VIII-X); elytra reddish.

Head approximately 1.05 times as wide as long (Fig. 104); punctation rather sparse and fine; interstices with distinct microreticulation, much wider than diameter of punctures. Anterior margin of clypeus rather narrowly semi-membranous. Eyes large and distinctly convex, approximately as long as postocular region in dorsal view.

Pronotum large, 1.25-1.30 times as wide as long and 1.5-1.7 times as wide as head; posterior angles almost obsolete, rounded (Fig. 104); punctation fine, shallow, and moderately dense; interstices on average somewhat wider than diameter of punctures and with shallow microreticulation.

Elytra $0.75-0.85$ times as long as pronotum; punctation distinctly coarser and slightly sparser than that of pronotum (Fig. 104); interstices wider than diameter of punctures, with or without shallow microsculpture. Hind wings fully developed. Metatarsomere I approximately as long as combined length of II-IV. 
Abdomen distinctly narrower than elytra, widest at segments III-IV, posteriorly distinctly tapering (Fig. 105); punctation of anterior impressions of tergites III-VI moderately dense and rather fine; interstices without appreciable microsculpture and very glossy.

$\sigma^{*}$ : punctation of posterior halves of tergites III-VI conspicuously sparse (almost impunctate in the middle); abdominal tergite III posteriorly with weakly elevated, smooth, circular, and apically pointed tubercle; tergite IV with (large male) or without (small male) less pronounced median tubercle of similar shape (Fig. 105); tergite VII with erect, stout median process at posterior margin (Fig. 106); sternites IV and V with weakly transverse, well-defined, and slightly impressed patches with pronounced microsculpture and dense long pubescence (Fig. 80-81); posterior margin of tergite VIII truncate or indistinctly angled in the middle; posterior margin of sternite VIII distinctly pointed in the middle (Fig. 107); aedeagus with median lobe $0.74-0.83 \mathrm{~mm}$ long; ventral process rather slender and smoothly curved in lateral view (Figs 10-12).

9 : punctation of posterior halves of tergites III-VI sparse, but less so than in male; tergites III, IV, and VII unmodified; sternite VIII weakly convex, almost truncate in the middle; spermatheca as in Fig. 56.

\section{Comparative notes:}

In coloration and body shape, this species is rather similar to A. erythroptera, but distinguished by less dense punctation of the forebody (especially of the pronotum and elytra), much sparser punctation of the abdomen, the shape of the tubercle on the male abdominal tergite III (in A. erythroptera usually more or less longitudinal), the occasional presence of a median tubercle on the male abdominal tergite IV (in $A$. erythroptera absent), the completely different modification of the male tergite VII (A. erythroptera: pair of tubercles or weakly elevated transverse elevation), the less transverse patches with long pubescence on the male sternites IV and V, as well as by the larger aedeagus with a longer and apically differently shaped ventral process in lateral view. For illustrations of $A$. erythroptera see Figs 4-5, 54, as well as figures 57-73 in Assing (2007).

\section{Distribution and bionomics:}

Aleochara diversicollis is known only from two localities in southwestern and southeastern France, and one in southeastern Spain (Map 2). It was doubtfully recorded also from northwestern Italy (Luigioni 1929, ZanetTi 1995). The paralectotype was found in August, the specimen from Spain was collected with a window-trap in late winter (February-March).

Aleochara (Ceranota) major FAIRMAIRE, 1858 (Figs 13, 57, 82-83)

Aleochara major FaIRMAIRE, 1858: $737 \mathrm{f}$.

\section{Type material:}

Neotype $0^{\star}$, present designation: D. Niedersachsen, Sieben Berge near Alfeld/L., Hörzen, XI.2000, A. Sührig / Neotypus ơ Aleochara major Fairmaire, desig. V. Assing 2009 (MNHNP).

\section{Comment:}

The original description is explicitly based on a single specimen from "Mont-Dore" (Massif Central; $45^{\circ} 35^{\prime} \mathrm{N}, 2^{\circ} 50^{\prime} \mathrm{E}$ ) collected by "M. Bayle" (Fairmaire 1858). The holotype was looked for in the Fairmaire collection at the MNHNP, but only the labels were found; the specimen is apparently lost (TAGHAVIAN, e-mail 11 August, 2009). In order to secure the current interpretation of the species, the above neotype is designated. 


\section{Additional material examined:}

Germany (see also Assing 1994, 2001a): Nordrhein-Westfalen: 2 exs., Porta Westfalica, Wittekindsberg, 3.XI.1992, leg. Borcherding (cAss); 1 ex., Marsberg [51"27' N, 851'E], Kregenberg, 3.X.1993, leg. Lückmann (cAss); 5 exs., Warburg, Scherfede, Hellberg, pitfall, 1.XI.1981, leg. Renner (cRen); 2 exs., same data, but 29.XI.1981 (cRen); 2 exs., Höxter, Riesel/Brakel, Hamberg, pitfall, 1.XI.1981, leg. Renner (cRen); 1 ex., same data, but 27.I.1982 (cRen); 1 ex., same locality, 23.XI.1983, leg. Renner (cWun). Niedersachsen: 1 ex., 3 km NE Alfeld/Leine, Wernershöhe, 300 m, arable land, pitfall, X.1998, leg. Schmidt (cAss); 4 exs., Alfeld/Leine, Sieben Berge, Ostenberg, XI.2000, leg. Sührig (cAss); 1 ex., 2 km SE Wolfenbüttel, Öselberg, 150 m, pitfall, XI.1998, leg. Schmidt (cAss); 6 exs., same data, but XI.1999 (cAss); 1 ex., E Schladen, Hedeper, Westerberg, pitfall, XI.2001, leg. Schmidt (cAss). Thüringen: 1 ex., Arnstadt, 30.IX.1945, leg. Liebmann (SDEI).

\section{Diagnosis:}

Body length 4.5-9.0 mm; habitus slender. Coloration: head blackish-brown to blackish; pronotum reddish to dark-brown with the margins narrowly reddish; elytra reddish; abdomen reddish, with tergites III-V often infuscate in the middle, tergites VI and VII extensively infuscate with the margins reddish.

Clypeus with anterior margin rather narrowly semi-membranous. Pronotum relatively slender, 1.18-1.26 times as wide as long and 1.40-1.55 times as wide as head; posterior angles weakly marked. Anterior impressions of tergites III-VI with moderately dense to very dense and rather coarse punctation; tergite VII with rather coarse punctation of variable density (moderately sparse to dense).

$\sigma^{*}$ : median portions of tergites III-VI very sparsely punctate, often almost impunctate; tergite III with more or less erect median tubercle or process of very variable shape: weakly elevated and apically pointed (small males), to strongly erect and apically longitudinally keeled or smoothly convex (large males); tergite IV with weakly elevated, apically keeled or pointed (small males) or smoothly convex median tubercle (large males); tergite $\mathrm{V}$ with or without very small median tubercle; tergite VII at posterior margin with moderately erect and apically usually pointed tubercle; sternites IV and V without impressions, but with rather large subcircular areas with pronounced microsculpture and with conspicuously dense and long pubescence (Figs 82-83); median lobe of aedeagus as in Fig. 13; ventral process shorter than basal portion of median lobe, in ventral view similar to that of $A$. erythroptera.

+ : median portions of tergites III-VI with rather coarse, moderately sparse to moderately dense punctation; tergites III with or without small median tubercle; tergites IV, V, and VII without tubercles; spermathecal capsule with relatively small distal portion and with very long and slender proximal portion (Fig. 57).

\section{Distribution and bionomics:}

The distribution of $A$. major requires clarification, also due to previous confusion with other Ceranota species (e.g., A. melichari; see KöHLER 1998), partly as a result of the characters and distribution indicated in the key by LikovskÝ (1974). Confirmed records have become known only from France, Belgium, the Netherlands, and Germany (Horion 1967, SMEtana 2004, Vogel 1998). Recently, the species was doubtfully recorded also from northern Austria (ScHaTz et al. 2003). For additional records see Assing (1994, 2001a), Feldmann \& Lückmann (1998), Jung (2001), Junker (2001), Köhler (1998), and Renner (2001).

This species has been collected primarily in colline xerothermous habitats, particularly calcareous grassland, vineyards, and extensively managed grassland orchards, mostly with pitfall traps (Assing 1994, 2001a, Feldmann \& Lückmann 1998, Jung 2001, KöHLer 1998; material examined). 
JUNKER (2001) sifted a specimen from decaying organic matter. All the records were made during the period from September through November, with a maximum in October, suggesting that this is when dispersal takes place. On several occasions, flying specimens were observed in October. Teneral beetles were found in September.

Aleochara (Ceranota) melichari (REITTER, 1889) (Figs 14, 84-85, 108-110)

Ceranota melichari ReITTER, 1889: $370 \mathrm{f}$.

Type material examined:

Lectotype $\sigma^{\star}$ [dissected prior to present study]: $\sigma^{\star} /$ Dalmat. / Dr. Melichar, Al. Melichari Reitt. Typ. / Typus / Aleochara melichari det. Vogel 1989 / Lectotypus ơ Ceranota melichari Reitter desig. V. Assing 2007 / Aleochara melichari (Reitter) det. V. Assing 2007 (NHMW). Paralectotype: o / Dalmatien, Dr. Melichar / Ceranota Melichari m. / coll. Reitter / Holotypus Ceranota Melichari Reitter 1888 / Aleochara melichari, det. J. Vogel, 2008 (HNHM).

\section{Comment:}

The original description is based on an unspecified number of syntypes "von Herrn Dr. Melichar in Dalmatien aufgefunden" (ReitTer 1889). Two of them, both males, was located in the collections of the HNHM and the NHMW. The syntype from the NHMW is designated as the lectotype.

\section{Diagnosis:}

Relatively large species; body length 7.2-7.6 mm; habitus moderately slender (Fig. 108). Coloration: head blackish-brown; pronotum reddish-brown with broadly reddish lateral margins; elytra reddish, near scutellum diffusely infuscate; abdominal segments III-V reddish; segment VI blackish with posterior margin narrowly reddish; segments VII blackish, with posterior third reddish; segments VIII-X reddish.

Head with shallow microsculpture. Anterior margin of clypeus rather narrowly semi-membranous. Antennae very long and slender; antennomere X approximately as long as wide. Pronotum moderately slender and moderately large in relation to head, 1.15-1.23 times as wide as long and 1.55-1.60 times as wide as head; posterior angles weakly marked (Fig. 109); microsculpture shallow. Elytra relatively long, approximately 0.85 times as long as pronotum (Fig. 109). Abdomen, including anterior impressions of tergites III-VI, with dense and coarse punctation; interstices without, or with very shallow traces of microsculpture.

$\sigma^{x}$ : tergite III with enormous, strongly erect median process; tergite IV with much smaller, apically acute median tubercle; tergite VII at posterior margin with weakly erect, weakly elevated, apically acute median tubercle (Fig. 110); sternites IV and V with more or less oval patches with distinct microsculpture and dense long pubescence (Figs 84-85); median lobe of aedeagus approximately 0.9-1.0 mm long, ventral process blade-shaped, i.e., laterally strongly compressed (Fig. 14).

ㅇ: not examined; spermatheca as figured by VOGEL (1998).

\section{Distribution:}

This apparently extremely rare species is currently known only from Croatia (Vogel 1998). Aside from the two type specimens, no additional material was found in all the collections examined. The vast majority of previous records are largely based on misidentifications and doubtful. 
Aleochara (Ceranota) penicillata Peyerimhoff, 1901 (Figs 15-18, 58, 86-87)

Aleochara (Ceranota) penicillata PeYerimhoff, 1901: $347 \mathrm{f}$.

Aleochara (Ceranota) caprae GridelLI, 1922: 26 f.; syn. n.

Aleochara (Ceranota) meschniggi Bernhauer, 1943: 187 f.; syn. n.

\section{Type material examined:}

A. penicillata and A. caprae: Holotype $\sigma^{\top}$ [dissected prior to present study]: Ceranota penicillata $\sigma^{\star}$ Peyerimhoff, type, Dourbes, 23.4.1901 / Type / Muséum Paris / Holotypus Aleochara penicillata Peyerimhoff rev. V. Assing 2009 / Neotypus o Aleochara caprae Gridelli, desig. V. Assing 2009 / Aleochara penicillata Peyerimhoff, det. V. Assing 2009 (MNHNP).

A. meschniggi: Lectotype $\sigma^{\star}$, present designation: $\sigma^{\star} / 5193$ / Kärnten, Obir, Ing. Meschnigg / Beim 2. Expl. Höcker am 4. Terg. fast 0 / Meschniggi Brnh. Typus Ceranota [white label] / Meschniggi Bernh. Typus Ceranota [red label] / Chicago NHMus M.Bernhauer Collection / Lectotypus ơ Aleochara meschniggi Bernhauer desig. V. Assing 2007 (FMNH).

\section{Comment:}

The original description of $A$. penicillata is based on a single male from "Dourbes, près Digne, le 23 avril 1901" Peyerimhoff 1901).

Aleochara meschniggi was described from two syntypes collected "von Ing. A. Meschnigg am Obir (Kärnten)" (Bernhauer 1943). One of them, a male, was found in the Bernhauer collection at the FMNH and is designated as the lectotype. The whereabouts of the other syntype, now a paralectotype, are unknown; it was not found in the collections of the NHMW. An examination of the type material of $A$. penicillata and $A$. meschniggi revealed that they are conspecific; hence the synonymy proposed above.

The original description of $A$. caprae is based on a single male collected by F. Capra near "Torino (Colli S. Margherita)" (Gridelli 1922). The holotype is evidently lost. It was looked for, but not found in the collections of the natural history museums in Milano and Trieste (Rigato pers. comm., Colla pers. comm.), where the Gridelli collection is deposited, by the respective curator in charge. According to GrIDELLI (1922), the species is characterised by the coloration (pronotum blackish-brown, with the margin narrowly and the posterior angles extensively reddish, abdomen reddish, except for the blackish segments VII and VIII), the almost impunctate abdominal tergites (probably III-VI; "parte apicale dell'addome danneggiata, purtroppo non sono in grado di descrivere gli eventuali caratteri dei due ultimi tergiti"), and the modification of the male abdominal tergite III ("sporgenza vistosa"). This description is in good agreement with the species previously referred to - and recorded as - $A$. meschniggi from the Alps. The species has never been recorded again since its original description. Also, ZaneTti (pers. comm.) has seen only $A$. meschniggi from the region where the type locality of $A$. caprae is situated. In conclusion, it can be inferred from these observations that, like $A$. meschniggi, $A$. caprae is conspecific with, and a junior synonym of $A$. penicillata. In the interest of the stability of nomenclature, the holotype of $A$. penicillata is designated as the neotype of $A$. caprae, thus rendering the proposed synonymy objective.

\section{Material examined:}

France: Provence: 1 \% , Alpes-Maritimes, Roquebilière, 10.XI.1937 (NHMW).

Germany: Bayern: 1 ex., Starnberg, Seegebiet, Mühltal, 11.II.1954, leg. Friesen (NHMW); 3 exs., München, Isar valley, 3.\&9.I.1939 (NHMW); 2 exs., München, Isar valley, Georgenstein, 14.I.1939 (NHMW); 1 ex., München, Grünwald, 10.XII.1939, leg. Ihssen (cAss); 1 ex., München, Grünwald, 9.II.1940, leg. Kulzer (MNHUB); 1 ex., München, 24.I.1939, leg. Ihssen (MNHUB); 1 ex., Grünberg, Isar valley, 5.I.1952 (SDEI); 1 ex., Grünberg, Isar valley, 21.I.1941 (SDEI); 2 exs., Garmisch-Partenkirchen env., Elmau, 29.I.1939, leg. Ihssen (MNHUB). 
Austria: Tirol: 6 exs., Innsbruck env., Rechenhof, on snow, 12.\&14.I.1938, leg. Wörndle (MNHUB, NHMW, cAss); 2 exs., same data, but 23.XII.1937 (NHMW, cAss); 1 ex., same data, but 7.I.1937 (MNHUB). Niederösterreich: 1 ex., Neustadt (NHMW); 2 exs., Mödling, leg. Scheerpeltz (NHMW); 2 exs., Bad Vöslau (NHMW); 1 ex., Semmering (NHMW). Burgenland: 1 ex., Oberwart, Mark Allhau, 400 m, resin on spruce, 25.II.2000, leg. Holzer (cAss). Locality ambiguous: 1 ex., Wildegg, snow (NHMW).

Italy: Veneto or Friuli-Venezia Giulia: 1 ex., Cansiglio (NHMW); 1 ex., Mte. Cavallo (NHMW).

Slovenia: 1 ex., Bitež near Gorizia (NHMW).

\section{Diagnosis:}

Body length 6.0-9.0 mm; habitus moderately slender. Coloration: head dark-brown to blackish; pronotum brown to dark brown, with reddish margins; elytra yellowish-red; abdomen reddish, with segments VI, VII (often except for posterior margin), and anterior portion of VIII infuscate. Whole forebody with distinct microreticulation and almost matt. Anterior margin of clypeus rather broadly semi-membranous. Pronotum moderately slender, 1.24-1.28 times as wide as long and 1.55-1.68 times as wide as head; posterior angles weakly marked or obsolete. Punctation of abdomen with sexual dimorphism.

$\sigma^{\star}$ : anterior impressions of tergites III-VI very sparsely punctate, posterior portions of these tergites with rather sparse punctation; tergite VII with denser, but relatively fine punctation; tergite III in large male with strongly erect median process, in small male with less pronounced tubercle; tergite IV in large male with erect and apically pointed median tubercle (somewhat less pronounced than that of tergite III), in small male with with simple median tubercle; tergite V with (large male) or without (small male) apically weakly pointed or smoothly convex median tubercle; tergite VI with (large male) or without (small male) very small median tubercle; tergite VII at posterior margin with transverse median elevation, this elevation sometimes depressed in the middle and granulosely sculptured; sternites IV and V without impressions, but with well-defined and moderately extensive, transversely oval patches with distinct microsculpture and with dense long pubescence (Figs 86-87); median lobe of aedeagus relatively large, approximately 0.85-0.95 mm long; ventral process subapically weakly angled and apically very slender in lateral view (Figs 15-18).

$\%$ all tergites, including anterior impressions of tergites III-VI, with rather dense and distinct punctation; tergite III with or without indistinct median tubercle; other tergites unmodified; spermatheca as in Fig. 58.

\section{Distribution and bionomics:}

The examined material reveals that $A$. penicillata is widespread in all of the Alps. The above specimen from Slovenia represents a new country record. The record from Bosnia-Herzegovina would significantly expand the known range of the species towards the southeast, but should be considered tentative, since it is exclusively based on females. For additional records (as A. melichari or A. meschniggi) see Heiss (1971) Kahlen (1987), Kofler (1980), Lupi et al. (2006), Schatz (2008), and Wörndle (1950). Previous records of $A$. melichari from the Alps probably all refer to $A$. penicillata (Likovský 1974, Vogel 1998); Horion (1967) only lists the type specimens of A. meschniggi, but numerous, most likely erroneous records of $A$. melichari from the Alps; the circumstances of collection indicated for $A$. melichari (on snow, leaf litter, rotting grass, moss) undoubtedly refer to $A$. penicillata. One of the examined specimens was found on spruce resin.

Most of the examined material with labels specifying the date of collection was found in January and February; the holotype of $A$. penicillata was collected in April. Horion (1967) indicates the period from the end of October to the middle of February (as A. melichari). 
Beitr. Ent. 59 (2009) 2

Aleochara (Ceranota) opacina FAUVEL, 1900 (Figs 19, 60, 88-89, 111-113)

Aleochara (Ceranota) opacina Fauvel, 1900: $246 \mathrm{f}$.

\section{Type material examined:}

Lectotype $\sigma^{\star}$, here designated: $\sigma^{\star}, 2748$ / Aragnouet, prairies subalp., montan herbes, 7, 8 / Type / Lectotypus o Aleochara opacina Fauvel rev. V. Assing 2007 / Aleochara opacina Fauvel det. V. Assing 2007 (IRSNB). Paralectotypes: $1 \sigma^{\text {t }}$ : same data [and on same pin] as lectotype (IRSNB); 3 exs.: ㅇ 2748 / Type (IRSNB); $10^{\star}$ [head and pronotum missing]: Suisse / Pic de Couar (B. Alpes) 7, 1 ㅇ (Peyerimh.) / Evoléne 8 (Alp. mar.) / Typus (IRSNB).

\section{Comment:}

The original description is based on an unspecified number of syntypes from "Haut-Pyrénées: Aragnouet", "Basses-Alpes: pic de Couar", "Alpes Maritimes: Saint-Martin-Vésubie", and "Suisse" (FAUVEL 1900). A relatively large male in reasonably good condition from Aragnouet is designated as the lectotype.

Additional material examined:

France: Provence: 2 exs., Alpes-Maritimes, St. Martin-Vesubie, 8.VI.1997, leg. Ziegler (cAss); 1 ex, AlpesMaritimes, Col de la Bonnette, 1900 m, 30.VII.2000, leg. Ziegler (cAss); 1 ex., Alpes-Maritimes, Sussy, 1300 m, 15.VIII.1952 (NHMW); 1 ex., Alpes-de-Haute-Provence, Allos, lac de la petite Cayolle, 2590 m, pitfall, 22.VIII.1998, leg. Coache (cTro).

Ukraine: 1 , Mykolayiv oblast, Pervomaisk district, Kuripchino, 12.VII.2002, leg. Gontarenko (cAss).

\section{Diagnosis:}

Body length 4.5-8.0 mm; habitus broad. Coloration: head, pronotum, and abdomen, except for the reddish posterior margins of segments III-VII and segments VIII-X, blackish; pronotum and abdomen rarely dark-brown; elytra reddish to yellowish-red.

Whole forebody with conspicuously fine and dense punctation (punctation of elytra finely granulose), with pronounced microreticulation (Fig. 112), almost matt, and with very short, depressed pubescence. Clypeus completely semi-membranous (Fig. 113). Eyes distinctly shorter than postocular region in dorsal view. Pronotum strongly convex in cross-section, of variable proportions, 1.3-1.5 times as wide as long and 1.3-1.6 times as wide as head; posterior angles weakly marked or obsolete; posterior margin conspicuously convex. Elytra short, 0.70-0.75 times as long as pronotum, suture at sutural angles gaping. Abdomen with relatively deep anterior impressions of tergites III-VI; punctation of tergites III-VI, including anterior impressions, dense and usually rather coarse (Fig. 111); punctation of tergite VII dense, sometimes somewhat finer than that of anterior tergites.

$\sigma^{\star}$ : abdominal tergite III posteriorly with subcircular, weakly elevated, and apically smoothly convex (small male) to longitudinal, apically keeled, and weakly (small male) to distinctly erect (large male) median tubercle; tergite IV without distinct tubercle, in large male sometimes with small impunctate median area; tergite VII at posterior margin with weakly elevated transverse median tubercle (small male) to strongly erect median process (large male) (Fig. 111); sternites $\mathrm{IV}$ and $\mathrm{V}$ with extensive transverse patches with pronounced microsculpture and with dense long pubescence (Fig. 88-89); aedeagus with ventral process of median lobe and internal structures of distinctive morphology (Fig. 19).

ㅇ: tergites III, IV, and VII without tubercles; spermatheca as in Fig. 60, proximal portion of capsule stout. 


\section{Distribution and bionomics:}

Aleochara opacina was previously known only from the Pyrenees and the western Alps (France, Andorra, Switzerland, Italy) (Fagel 1968, Jarrige 1968, Luigioni 1929, Peyerimhoff \& Sainte-Claire Deville 1901, Smetana 2004). The above specimen from Ukraine is a female, but based on the distinctive external morphology (shape of pronotum, punctation and microsculpture of the forebody, coloration, etc.) it is apparently conspecific with the material from the western Alps and with the type material examined. If indeed this is the case, the distribution of A. opacina would be remarkably discontinuous. According to JARRIGe (1968), the species may be associated with ants, but this seems rather unlikely. The true reproduction habitat is probably subterranean and essentially unknown.

Aleochara (Ceranota) strasseri BERnHAUER, 1901 (Figs 20-21, 61-62, 90-91, 114, Map 3)

Aleochara (Ceranota) strasseri BeRnHAUER, 1901: $492 \mathrm{f}$.

Aleochara (Ceranota) matzenaueri RAMBоUSEK, 1907: 15 ff.; syn. n.

\section{Type material examined:}

A. strasseri: Holotype + : Travnik / Strasseri Brnh. Bosnien. Strasser. Type / Holotypus Aleochara strasseri Bernhauer rev. V. Assing 2007 / Aleochara strasseri Bernhauer det. V. Assing 2007 (FMNH).

A. matzenaueri: Neotype + , present designation: Bosnia, Bjelašnica-Pl., O. Leonhard / Aleochara Strasseri Brh. / Aleochara Strasseri Bernh. / coll. DEI Müncheberg / Neotypus \& Aleochara matzenaueri Rambousek, desig. V. Assing 2009 / Aleochara strasseri Bernhauer, det. V. Assing 2009 (SDEI).

\section{Comment:}

The original description of $A$. strasseri is based on a single holotype specimen from "Travnik in Bosnien", which, owing to the presence of a tubercle on the abdominal tergite III, Bernhauer (1901) believed to be a male, but which is in fact a female.

Aleochara matzenaueri was described from a single female from "Sarajevo (Bosnie)" (RAmbouseK 1907). Despite careful search, the specimen was not found in the collections of the natural history museum in Prague, where it should be deposited (HÁjEK, e-mail 12 August, 2009). The species has never been recorded again since the original description, suggesting that it is conspecific with one of the other representatives of the subgenus recorded from the Balkans. According to the habitus illustration provided by RamBousex (1907), the holotype has antennae with distinctly transverse antennomeres VI-X and a completely semi-membranous clypeus, just like $A$. strasseri. Therefore, a female specimen of $A$. strasseri from Bosnia-Herzegovina in the collections of the SDEI is designated as the neotype of $A$. matzenaueri, which is consequently placed in synonymy with $A$. strasseri.

Additional material examined:

Bosnia-Herzegovina: 1 ex., Maklen pass (NHMW); 8 exs., Bjelašnica planina, leg. Leonhard (NHMW, SDEI, cAss); 1 ex., Prozor, leg. Leonhard (SDEI).

Serbia: 3 exs., Suva planina, 700 m, 26.V.2002, leg. Stévanovič (cAss).

Greece: 1 ex., Thessaloniki env., Khortiátis, 28.IV.1960, leg. Kühnelt (NHMW); 1 ex., Fthiótida, Oros Oxiá, road Gardíki-Gramméni Oxiá, 1520 m, beech forest, 10.VI.1995-11.VI.1996, leg. Giachino \& Vailati (cVai); 1 ex., Fthiótida, Oros Oxiá, road Gardíki-Gramméni Oxiá, 1470 m, beech forest, 3.VI.199810.VI.1999, leg. Giachino \& Vailati (cAss). 


\section{Diagnosis:}

Body length 5.5-8.0 mm; habitus relatively slender. Coloration: head blackish; pronotum brown to blackish, with the margins narrowly, at posterior angles extensively reddish; elytra reddish, rarely with lateral margins diffusely infuscate; abdomen usually blackish with the posterior margins of the segments reddish, rarely brown with the posterior margins of the segments broadly reddish.

Head with distinct, pronotum with shallower, but noticeable microreticulation. Clypeus completely semi-membranous (Fig. 114). Eyes situated on dorso-lateral slope of head (i.e., orientation not vertical, but oblique), small, distinctly shorter than postocular region in dorsal view. Antennae conspicuously short and incrassate apically, not - or only barely - reaching posterior margin of pronotum when directed caudad; antennomeres VI-IX approximately twice as wide as long or nearly so. Pronotum relatively small in relation to head, 1.27-1.35 times as wide as long and 1.30-1.45 times as wide as head; posterior angles weakly marked or obsolete; punctation fine and dense. Elytra short, 0.75-0.85 times as long as pronotum. Abdomen, including anterior impressions of tergites III-VI, with moderately coarse and moderately dense to dense punctation. Modifications of tergites III and IV similar in both sexes: tergite III posteriorly with small, apically smoothly pointed or longitudinally keeled median tubercle; tergite IV with or without very small median tubercle.

$\mathrm{o}^{\star}$ : tergite VII at posterior margin with pair of small, smooth tubercles; sternites IV and V with pronounced and clear-cut, transversely kidney-shaped impressions with pronounced microsculpture and dense long pubescence (Figs 90-91); median lobe of aedeagus with very slender ventral process in lateral view (Figs 20-21).

\% : tergite VII with or without very weakly pronounced pair of tubercles or with weakly pronounced transverse elevation at posterior margin; spermatheca of somewhat variable shape (Figs 61-62).

\section{Distribution and bionomics:}

Aleochara strasseri was previously known only from Bosnia-Herzegovina (SMETANA 2004), but is apparently widespread in the Balkan peninsula (Map 3). The above specimens from Serbia and Greece represent new country records. The material from Greece (Fthiódida) was collected with subterranean pitfall traps in beech forests.

Aleochara (Ceranota) hydrocephala FAUvEL, 1900 (Figs 22, 63, 96-97, 115, Map 2) Aleochara (Ceranota) hydrocephala FAUvel, 1900: $245 \mathrm{f}$.

\section{Type material examined:}

Syntypes: 1 : $:$ / / Gap / Dijon / Cauterets / Type (IRSNB); 1 : : Gannet, 4 / Type (IRSNB); 1 : $\sigma^{\star}$ [sic]: Le Puy, 5 / Ossan, B. Pyr. / Aragnouets, Cauterets [rest illegible] / Type (IRSNB).

\section{Comment:}

The original description is based on an unspecified number of syntypes from "Gannat, avril; Le Puy, mai! Gap! Dijon ...; Hautes-Pyrénées: Aragnouet, Eaux-Bonnes, Cauterets, Gavarnie" (FAUVEL 1900). Since the type material at the IRSNB does not include a male, a lectotype is not designated. 
Additional material examined:

Spain: Galicia: 4 exs., Lugo, Serra do Rañadoiro, Alto de Poio, 1470 m, 25.IX.2003, leg. Valcárcel (cSch, cAss). Asturias: 1 ex., NE Puerto de Ventana, 1580 m, 13.VI.2000, leg. Aßmann (cFel). Castilla-León: 1 ex., Soria, Sierra de Urbión, above Laguna Negra, 1900 m, 21.V.1999, leg. Feldmann (cFel); 1 ex., Soria, Sierra de Urbión, path from Puerto de St. Ines to Pico de Urbión, 1750-2000 m, 26.V.1994, leg. Schülke \& Grünberg (cAss); 1 ex., Sierra de Ancares, Miravalles peak, 42 $53^{\prime} \mathrm{N}, 6^{\circ} 47^{\prime} \mathrm{W}, 1960 \mathrm{~m}, 15 . \mathrm{VII} .2004$, leg. Assing (cAss). Aragón: $1 \mathrm{o}^{\star}$, Forla-Biescas, car-net, 13.VI.1991, leg. Wunderle (cWun). Andalucía: 2 exs., Granada, Sierra de la Sagra, 2000-2380 m, 30.IV.1991, leg. Tronquet (cTro).

France: Languedoc-Roussillon: 1 , Pyrénées-Orientales, southern slope of Mt. Canigou, Les Estables [ $42^{\circ} 27^{\prime} \mathrm{N}, 2^{\circ} 27^{\prime} \mathrm{E}$ ], 2000 m, VII.1972, leg. Poot (cAss); $1 \mathrm{o}^{\star}$, Gard, [Saint-Paulet-de-] Caisson, 22.III.2001, leg. Lambelet (cTro).

\section{Diagnosis:}

Body length $4.0-8.5 \mathrm{~mm}$; habitus relatively slender, general appearance similar to that of A. strasseri. For a colour habitus image see the illustration of $A$. erythroptera in TrONQUET (2006). Coloration: head, pronotum, and abdomen blackish; elytra reddish.

Head with shallow, but distinct, pronotum usually with even shallower microreticulation. Head large in relation to pronotum. Eyes situated on dorso-lateral slope of head (i.e., orientation not vertical, but oblique), small, distinctly shorter than postocular region in dorsal view. Clypeus completely semi-membranous (Fig. 115). Pronotum small in relation to head, 1.30-1.45 times as wide as long and 1.35-1.48 times as wide as head; posterior angles obsolete. Abdomen, including anterior impressions of tergites III-VI, with moderately coarse, moderately sparse to moderately dense punctation.

$0^{\star}$ : tergite III with small median tubercle; tergite VII at posterior margin with weakly elevated transverse elevation; sternites IV and V with well-delimited, shallow, somewhat kidney-shaped transverse impressions with pronounced microsculpture and with dense long pubescence (Figs 9697); median lobe of aedeagus shaped as in Fig. 22.

: tergites III, IV, and VII usually without tubercles; spermatheca as in Fig. 63.

\section{Distribution and bionomics:}

Aleochara hydrocephala was previously known from several localities in France (see comment above), from the Pyrenees to the western Alps (Fauvel 1900), but is apparently widespread in southwestern Europe (Map 2). Tronquet (2006) indicates an additional locality in Aude. The above specimens from Spain represent new country records.

According to Fauvel (1900), some of the type material was found in moss. The additional material listed above was collected mostly by sifting litter of leaves and shrubs at altitudes of 1470$2000 \mathrm{~m}$. In contrast to most other Ceranota species, $A$. hydrocephala seems to be epigeically active for a rather long period (April-September) (FAUvel 1900; material examined). One specimen was collected on the wing (car-net) in June. Teneral beetles were recorded in September.

\section{Aleochara (Ceranota) purkynei RoubAL, 1937 (Figs 25, 64, 92-93, Map 3)}

Aleochara (Ceranota) Purkynei Roubal, 1937: $329 \mathrm{f}$.

\section{Comment:}

According to the original description, the type specimens are males collected in "Graecia: Peloponesos [sic], im Kot" and deposited in the Roubal collection (Roubal 1937). The syntypes were examined by Likovsky (1973), who states that one of the syntypes is in fact a female. 
The type specimens were not examined, but based on the details indicated in the description and the distribution, there is no doubt that the present interpretation is correct.

Material examined:

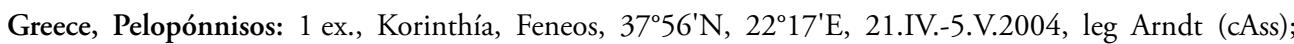
2 exs., Arkadia, Taygetos, road to Prof. Ilias, between Paleapanagia and Katafigio, 750 m, 30.IV.1999, leg. Wolf (cSch); 1 ex., Ilia, Erimanthos, 4 km N Plaka, 900 m, 5.V.1999, leg. Brachat (cAss); 1 ex., Lakonia, Taygetos, Poliana, 1.VI.1998, leg. Daccordi (cAss); 1 ex., Megalo Spilaion ["Megaspilion"; 3805'N, $\left.22^{\circ} 10^{\prime} \mathrm{E}\right]$, 1.V.1922, leg. Liebmann (SDEI).

\section{Diagnosis:}

Body relatively broad, 6.0-9.0 mm long. Coloration: head, pronotum, and abdomen blackish, pronotum sometimes slightly paler, dark-brown; elytra reddish, with the lateral and anterior margins sometimes somewhat infuscate.

Head relatively coarsely and rather densely punctured; clypeus anteriorly rather broadly semimembranous. Eyes relatively small, slightly to distinctly shorter than postocular region in dorsal view.

Pronotum with very dense and rather coarse punctation; interstices distinctly narrower than diameter of punctures. Pronotum relatively slender, 1.30-1.35 times as wide as long and 1.41.5 times as wide as head; posterior angles almost completely obsolete. Anterior impressions of tergites III-VI with moderately dense and rather coarse punctation; median portion of tergites III-V with sparse punctation; tergites VI-VII with rather dense and coarse punctation; tergites III, IV, and VII in both sexes modiied (without sexual dimorphism); tergite III in posterior half with longitudinal, distinctly elevated, apically keeled or smoothly rounded median tubercle; tergite IV in posterior half with weakly elevated, longitudinal, and apically usually distinctly keeled median tubercle; tergite VII posteriorly with distinctly erect, strongly elevated, apically pointed or briefly keeled, and laterally often somewhat compressed median tubercle.

$0^{*}$ : sternites IV and V in anterior half with subcircular and sharply delimited impressions with dense long pubescence (Figs 92-93); median lobe of aedeagus with rather long and slender ventral process (ventral aspect similar to that of $A$. erythroptera), and with rather long and slender apical structures in internal sac (Fig. 25).

o: spermatheca larger than in other species of the subgenus (Fig. 64).

\section{Distribution and bionomics:}

The distribution of $A$. purkynei is confined to the Pelopónnisos, southern Greece (Map 3), where it was sifted from leaf litter or found in excrements in spring (April-June) (RoubAL 1937; material examined).

Aleochara (Ceranota) caucasica EPPELSHeIm, 1889 (Figs 26-28, 116-121, Map 4)

Aleochara (Ceranota) caucasica Eppelsheim, 1889a: $11 \mathrm{f}$.

\section{Type material examined:}

Holotype $\sigma^{\star}$ : Novorossijsk, 18/IV 78. / Aleochara caucasica Epp. / c. Eppelsh. Steind. d. / caucasica Epp. Wien. ent. Zt.VIII.1889. p. 11 / Typus / Holotypus Aleochara caucasica Eppelsheim rev. V. Assing 2006 (NHMW). 
Additional material examined:

Georgia: $1 \sigma^{\star}$, Svanetskiy Khrebet ["Swanetien"], leg. Leder \& Reitter (FMNH); 1 ㅇ, Likhskiy Khrebet ["Meskisches Gebirge"], leg. Leder \& Reitter (HNHM).

Russia: 1 , , "Circassien", leg. Leder \& Reitter (cAss).

\section{Comment:}

The original description is explicitly based on a single holotype specimen ("in einem einzigen Exemplare") collected "bei Novorossisk im Kuban'schen Landstrich an der Nordostküste des schwarzen Meeres" (EPpelsheim 1889a).

\section{Redescription:}

4.3-4.5 mm; habitus as in Fig. 116. Coloration: head blackish; pronotum brown to dark brown; elytra yellowish to yellowish-brown, with the posterior external angles extensively infuscate; abdomen dark brown, with the apex and the posterior margins of the segments reddish; legs yellowish; antennae reddish-brown, with the basal three antennomeres yellowish to reddish-yellow.

Head of subquadrate shape, less than 1.05 times as long as wide (Fig. 117); punctation moderately sparse and very fine; interstices with distinct microreticulation; eyes large, approximately as long as postocular region in dorsal view; clypeus anteriorly narrowly semi-membranous. Antenna moderately long and slender, antennomeres IV-X gradually and weakly increasing in width; preapical antennomeres weakly transverse, approximately 1.5 times as wide as long; antennomere XI approximately as long as the combined length of IX-X (Fig. 118).

Pronotum (Fig. 117) distinctly transverse, approximately 1.3 times wide as long and 1.45-1.50 times as wide as head; maximal width approximately in the middle; lateral and posterior margins convex; punctation moderately dense and fine, but slightly more distinct than that of head; microreticulation similar to that of head.

Elytra 1.2 times as wide and at suture 0.85 times as long as pronotum; posterior margin near posterior angles sinuate; punctation dense and granulose, distinctly coarser than that of head and pronotum (Fig. 117). Hind wings apparently fully developed. Metatarsomere I approximately as long as the combined length of II-IV.

Abdomen widest at segments III-IV, gradually tapering posteriad (Fig. 119); tergites III-V with moderately deep, tergite VI with shallow anterior impressions; these impressions finely and moderately densely punctate, the remainder of the surfaces of tergites III-VI with relatively sparse and fine punctation; interstices glossy, without appreciable microsculpture; tergite VII with somewhat denser punctation, posterior margin with pronounced palisade fringe; posterior margin of tergite VIII very weakly convex, almost truncate.

$\sigma^{\star}$ : tergite III near posterior margin with rather small median tubercle (Fig. 119); tergite VII near posterior margin with small subcircular median granule (Fig. 120); posterior margin of tergite VIII truncate, not serrate (Fig. 121); sternites IV and V weakly modified, anteriorly with rather extensive, weakly delimited, transverse areas with pronounced microsculpture and moderately dense and long yellowish pubescence, but without impressions (see figures 91-92 in Assing 2007); sternite VIII acutely pointed posteriorly; median lobe of aedeagus of rather stout shape and with relatively short ventral process (Figs 26-28).

9 : similar to that of $A$. libanica (cf. Fig. 72).

For additional illustrations of the male from Georgia see figures 87-96 in Assing (2007).

\section{Distribution and bionomics:}

This species has been recorded from four Russian and Georgian localities in the Western Caucasus region (Map 4). Bionomic data are unknown. 
Aleochara (Ceranota) virilis sp. n. (Figs 29, 98-99, 122-125, Map 4)

\section{Type material:}

Holotype ơ: Russia, W-Caucasus, Adygeja, Mt. Oshten, WN sl., 1800 m, 3.-5.VI.1999, leg. Putchkov / Holotypus ơ Aleochara virilis sp. n., det. V. Assing 2009 (cAss).

\section{Etymology:}

The name (Latin, adjective: masculine) refers to the large aedeagus, one of the characters separating this species from its most closely related congeners.

\section{Description:}

$6.5 \mathrm{~mm}$; habitus as in Fig. 122. Coloration: head and abdomen blackish, with the broad posterior margins of segments III-VIII and the abdominal apex reddish; pronotum dark-brown with reddish margins; elytra reddish; legs reddish; antennae dark-brown, with antennomeres I-III reddish.

Head approximately as long as wide (Fig. 123); punctation fine, but distinct; interstices without distinct microsculpture, glossy, much wider than diameter of punctures. Eyes large, approximately as long as postocular region in dorsal view. Antennae relatively slender; antennomere $\mathrm{X}$ indistinctly transverse (Fig. 124).

Pronotum approximately 1.25 times wide as long and about 1.55 times as wide as head; maximal width approximately in the middle; lateral and posterior margins distinctly convex, posterior angles almost obsolete (Fig. 123); punctation rather dense (particularly in the middle of disc) and distinct; interstices without microsculpture and glossy.

Elytra at suture approximately 0.85 times as long as pronotum; posterior margin near posterior angles sinuate (Fig. 123); punctation moderately dense, distinct, but less clear-cut than that of pronotum. Hind wings fully developed. Metatarsomere I approximately as long as the combined length of II-IV.

Abdomen subparallel, weakly tapering posteriad (Fig. 125); anterior impressions of tergites III-V shallow, that of tergite VI very shallow; punctation relatively sparse, but distinct on tergites III-V (both in anterior impressions and on posterior surfaces), rather coarse and dense on tergites VIVII; posterior margin of tergite VII with pronounced palisade fringe; posterior margin of tergite VIII broadly convex, not serrate.

${ }^{*}$ : tergite III near posterior margin with rather small, smooth median tubercle; tergite VII without tubercles or elevations (Fig. 125); sternites IV and V anteriorly with rather extensive, weakly delimited, transverse areas with pronounced microsculpture and moderately dense and long yellowish pubescence, without impressions (Figs 98-99); sternite VIII acutely pointed posteriorly; median lobe of aedeagus approximately $0.75 \mathrm{~mm}$, shaped as in Fig. 29.

i: unknown.

\section{Comparative notes:}

Based on the morphology of the aedeagus, A. virilis is closely allied to $A$. caucasica and $A$. claviculata. It is readily distinguished from both of them particularly by the much larger aedeagus, the absence of microsculpture on, and the consequently glossy appearance of the forebody, and by the denser and more distinct punctation of the abdomen, particularly of tergites VI-VII. The possibility that $A$. virilis is conspecific with the doubtful $A$. lucidula (see the comments on this species in section 5) cannot be ruled out completely. However, it seems at least unlikely that it is identical to the interpretation of Bernhauer (1901), who states that $A$. lucidula has a broader and larger body than A. erythroptera, which is not true of $A$. virilis. 


\section{Distribution and bionomics:}

The type locality, Mount Oshten (=Gora Oshten; $\left.44^{\circ} 00^{\prime} \mathrm{N}, 39^{\circ} 56^{\prime} \mathrm{E}\right)$, is situated in Adygeya, West Caucasus, Russia (Map 4). The holotype was collected at an altitude of $1800 \mathrm{~m}$.

Aleochara (Ceranota) conviva EpPELSHEIM, 1878, revalidated (Figs 33, 51, 59, 65, 94-95, 100-101, 126-129, 151-154

Aleochara conviva Eppelsheim, 1878: 98; synonymised with A. lurida by Bernhauer (1901).

Type material examined:

A. conviva: Holotype ${ }^{\star}$ [nanistic specimen]: Kaukas, Leder, Mamudly. 4800'. 24.6.75. / coll. Reitter / Monotypus Aleochara conviva Eppelsheim / Aleochara lurida Motsch., Zb. Likovský det. 1965 / Aleochara conviva Eppelsheim, det. V. Assing 2009 (HNHM).

\section{Comment:}

Aleochara conviva was described from a single male collected "von H. Leder am 24. Juni 1875 bei Mamudly, 4800' hoch" (EpPeLsheim 1878). The holotype was located in the HNHM; it is a male at the low end of the size range.

Bernhauer (1901), who did not study type material, synonymised this species with $A$. lurida. A recent examination of the types of $A$. lurida by SEMENov (in prep.), however, revealed that A. lurida is conspecific with, and consequently a junior synomym of $A$. subtumida; for further details see the section on $A$. subtumida. Therefore, $A$. conviva is reinstated as a valid name.

Additional material examined:

Turkey: $2 \sigma^{\star} \sigma^{\star}, 1$ 우 , Bolu, Abant Dağı, 1400-1550 m, V.1967, leg. Fagel (IRSNB, cAss).

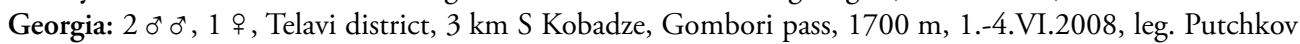
(cSch, cAss).

Armenian, Georgian, or Turkish territory: $10^{\star}$, "Armen. Geb.", leg. Leder \& Reitter (HNHM).

\section{Redescription:}

Highly variable species. Body length 3.9-7.0 mm; habitus as in Figs 126, 151. Coloration variable: head blackish; pronotum uniformly reddish to blackish-brown with more or less broadly reddish margins; elytra uniformly bright reddish, or dark-reddish with the portion adjacent to the scutellum and posterior angles diffusely infuscate; abdomen dark-brown to blackish, with the posterior margins of the segments reddish more or less distinctly reddish; legs reddish; antennae reddish to blackish-brown, with the three basal antennomeres more or less distinctly paler.

Head approximately as long as wide; punctation fine and sparse; microreticulation variable, very shallow to pronounced. Anterior margin of clypeus moderately broadly semi-membranous. Eyes moderately large and weakly bulging, approximately as long as postocular region or nearly so (Figs 127, 152). Antennae slender, weakly incrassate apically; antennomeres IV-X weakly transverse (Fig. 153).

Pronotum 1.3-1.4 times as wide as long and 1.50-1.65 times as wide as head, maximal width approximately in the middle; punctation fine and moderately dense to dense (Figs 127,152); microsculpture variable, shallow to pronounced.

Elytra 0.80-0.85 times as long as pronotum; punctation finely granulose, more distinct than that of pronotum, moderately dense (Figs 127, 152); interstices with distinct microreticulation. Hind wings fully developed. Metatarsomere I approximately as long as, or slightly longer than combined length of II-IV. 
Abdomen (Figs 129, 154) narrower than elytra, anterior impressions of tergites III-V shallow, that of tergite VI very shallow; tergites III-VI (including anterior impressions) with moderately sparse and fine punctation, tergite VII with somewhat denser and less fine punctation, especially in male; interstices with rather shallow transverse microsculpture and more or less glossy.

$\sigma^{*}$ : tergite III with weakly elevated and apically obtusely pointed or somewhat truncate median tubercle, or with subcircular smooth median tubercle in posterior half; tergite VII at posterior margin similarly with weakly elevated and apically obtusely pointed median tubercle (Figs 129, 154), near this tubercle and in posterior half sometimes with additional smaller granula; tergite VIII with or without coarsely granulose punctation, posterior margin truncate to weakly concave, and smooth or finely serrate (Fig. 128); sternites IV and V with well-delimited, slightly impressed patches with distinct microsculpture and dense long pubescence (Figs 94-95, 100-101); median lobe of aedeagus approximately 0.51-0.65 mm long, shaped as in Figs 33, 51.

$q$ : tergites III and VII unmodified; posterior margin of tergite VIII not serrate; posterior margin of sternite VIII strongly convex, almost pointed; spermathecal capsule with conspicuously stout proximal portion (Figs 59, 65).

\section{Distribution and bionomics:}

The above material was collected in Georgia and Turkey, with one specimen possibly from Armenia. According to Smetana (2004), this species has also been reported from the Russian South European territory. Since the interpretation of this species has always been doubtful, all previous records require confirmation.

Aleochara (Ceranota) claviculata sp. n. (Figs 30-32, 67, 130-133)

\section{Type material:}

Holotype ơ: TR [10] - Ordu, 34 km SSE Gölköy, W Mesudiye, 40²5'30"N, 37²7'29"E, 1520 m, 14.VII.2008, V. Assing / Holotypus o Aleochara claviculata sp. n., det. V. Assing 2009 (cAss). Paratypes: 1 ㅇ: same data as holotype (cAss); 1 ㅇ: same data as holotype, but leg. M. Schülke (cSch); 1 o $^{\star}$ [nanistic]: TR [2] - Rize, $17 \mathrm{~km} \mathrm{~S} \mathrm{Ardeşen,} 350 \mathrm{~m}$, stream bank, litter, $41^{\circ} 02^{\prime} 44^{\prime \prime} \mathrm{N}, 41^{\circ} 01^{\prime} 30^{\prime \prime E}, 10 . \mathrm{VII} .2008$, V. Assing (cAss).

\section{Etymology:}

The specific epithet (Latin, adjective) is derived from the Latin noun clavicula (small fork, key) and refers to the shape of the sclerotised internal structures of the aedeagus.

\section{Description:}

Body length 4.2-7.5 mm; habitus as in Fig. 130. Coloration: head blackish; pronotum dark-brown with reddish margins to almost completely reddish with the posterior median portion diffusely infuscate; elytra pale reddish (in paratype from Rize with weakly infuscate postero-lateral angles); abdomen blackish, with the posterior margins of segments III-VII and the posterior portion or all of tergite VIII reddish; antennae dark-brown, with antennomeres I-III and XI reddish.

Head approximately as wide as long, widest behind eyes (i.e., somewhat dilated posteriad); punctation very sparse and fine; interstices with pronounced microreticulation and almost matt. Anterior margin of clypeus moderately broadly semi-membranous. Eyes large, but weakly convex, approximately as long as postocular region in dorsal view or slightly longer (Fig. 131). Antennae moderately slender (Fig. 132). 
Pronotum strongly convex in cross-section and moderately broad, 1.25-1.30 times as wide as long and approximately 1.45-1.60 times as wide as head (Fig. 131), relatively broader in larger than in smaller specimens; posterior angles almost obsolete; punctation fine and dense; interstices on average as wide as diameter of punctures, somewhat shiny despite distinct microreticulation.

Elytra 0.85-0.90 times as long as pronotum; punctation finely granulose, distinctly coarser and sparser than that of pronotum (Fig. 131); interstices wider than diameter of punctures, with shallow microreticulation. Hind wings fully developed. Legs slender, metatarsomere I approximately as long as, or slightly longer than combined length of II-IV.

Abdomen distinctly narrower than elytra, widest at segments III-V, posteriorly weakly tapering (Fig. 133); punctation of dorsal surface sparse and very fine everywhere; interstices glossy and without distinct microsculpture.

$\sigma^{\lambda}$ : abdominal tergite III posteriorly with smooth, subcircular median tubercle; tergite VII at posterior margin with short, smooth, transverse, median ridge (reduced to minute indistinct tubercle in nanistic male) (Fig. 133); tergite VIII with indistinctly crenulate posterior margin; sternites IV and $\mathrm{V}$ with similar modifications as in $A$. conviva (cf. Figs 94-95), with well-defined, indistinctly impressed, transverse patches with pronounced microsculpture and dense, long pubescence; posterior margin of sternite VIII distinctly pointed in the middle; median lobe of aedeagus of compact shape, 0.51-0.60 mm long; ventral process short; internal structures of distinctive morphology (Figs 30-32).

$\rightarrow$ : abdominal tergites III and VII unmodified; spermatheca as in Fig. 67.

\section{Comparative notes:}

Based on the morphology of the aedeagus, A. claviculata is closely related to A. caucasica, from which it is distinguished by the more convex (cross-section), less broad, and anteriorly more strongly narrowed pronotum, the usually uniformly pale-reddish elytra, the longer metatarsomere I, the well-defined transverse patches with more pronounced microsculpture and denser pubescence on the male sternites IV and V, and by the different shapes of the ventral process, crista apicalis, and internal structures of the aedeagus. For illustrations of $A$. caucasica see Figs 26-28, 116-121, as well as Figs 87-96 in Assing (2007).

\section{Distribution and bionomics:}

The species was collected in two localities in Ordu and Rize provinces, northeastern Anatolia. The specimens were sifted from leaf litter, mostly in a beech forest, near small streams at altitudes of 350 and $1520 \mathrm{~m}$.

\section{Aleochara (Ceranota) subtumida (Hochнuтн, 1849) (Figs 34, 66, 134, Map 4)}

Myrmedonia subtumida Носннuтн 1849: $25 \mathrm{ff}$.

Aleochara lurida Motschulsky, 1860: 584 f.; synonymy by Semenov (in prep.).

\section{Type material examined:}

Lectotype $0^{\star}$ [only abdomen present; forebody missing]: Ekaterinograd / Aleochara lurida mihi, Caucasus / Lectotypus Aleochara lurida Motsch. V. B. Semenov dsg. 1998 / Aleochara subtumida (Hochh.), V. B. Semenov det. 1998 (ZMMU). Paralectotypes: 1 o [genitalia missing]: Ekaterinograd, V. B. Semenov scrpt. 1998 / Paralectotypus Aleochara lurida Motsch., V. B. Semenov dsg. 1998 / Aleochara lurida Mtsch. ? (aedoeagus fehlt!), V. B. Semenov det. 1998 (ZMMU); 1 ㅇ: Ekaterinograd, V. B. Semenov scrpt. / Paralectotypus Aleochara lurida Motsch., V. B. Semenov dsg. 1998 (ZMMU). 


\section{Comment:}

The original description, which is based on four syntypes, was published in a work on the beetle fauna of Caucasia and Transcaucasia; the precise localities where the syntypes were collected are not specified. According to Horn et al. (1990), the Hochhuth collection is deposited in the Zoological Institute in Kiev. Owing to the restrictive loan policy of the curating staff, it was not possible to examine the type material. However, based on the detailed original description, there is little doubt that the present interpretation of the species is correct.

The short original description of A. lurida, which is almost completely void of taxonomically significant details, was published in a work on the beetles of "Russie". It is based on an unspecified number of syntypes from "Ekatérinograd et en Géorgie à Sagerdan au pied des Montagnes du Caucase" (Motschulsky 1860). According to Horn et al. (1990), the Motschulsky collection is housed in the Zoological Museum in St. Petersburg, where the type material was looked for, but not found (KataEv, e-mail 16 September, 2009). A subsequent inquiry with the staff of the Zoological Museum Moscow, however, was successful. According to the curator in charge, three syntypes were found, one of them labelled as lectotype and two as paralectotypes by V. B. Semenov; the lectotype designation has not been published (Gusakov, e-mail 9 October, 2009). The lectotype, a male without forebody, was identified by V. Semenov as A. subtumida. Based on high-resolution photographs of all three type specimens, which were kindly sent to me by A. Gusakov, there is little doubt that the synonymy proposed by Semenov is correct.

\section{Material examined:}

Turkey [see also Assing 2004, 2006b, 2007]: 1 ex., Sinop, 15 km SW Sinop, S Kılıçlı, 41º57'N, 3502'E, 90 m, oak forest, sifted, 3.IV.2009, leg. Wunderle (cWun); 1 ex., Kastamonu, leg. Breuning (IRSNB).

Georgia: 1 ex., Telavi district, $3 \mathrm{~km} \mathrm{~S} \mathrm{Kobadze,} \mathrm{Gombori} \mathrm{pass,} 1700 \mathrm{~m}, 1 .-4 . V I I .2008$, leg. Putchkov (cSch).

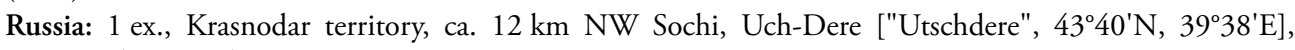
IV.1888, leg. Starck (NHMW).

Azerbaijan: 1 ex., Lerik, leg. Leder (NHMW).

Locality not specified or not identified: 1 ex., "Caucasus" (NHMW); 2 exs., "Kaukas.", leg Leder (HNHM, NHMW); 1 ex., "Circassien, Leder.Reitter" (NHMW).

\section{Diagnosis:}

Body relatively slender, 5.5-8.5 mm long. Coloration variable: head blackish; pronotum darkbrown to blackish, sometimes with the margins narrow reddish; elytra reddish; abdomen predominantly reddish (with tergites III-V anteriorly with a weakly infuscate spot and the middle of tergite VI blackish) to blackish with the posterior margins of the segments reddish.

Forebody (Fig. 134) without distinct microsculpture. Head conspicuously slender, approximately 1.15 times as long as wide. Clypeus anteriorly narrowly semi-membranous. Pronotum of characteristic shape, strongly narrowed anteriad, posteriad not - or very weakly - narrowed, weakly transverse and much wider than head, approximately 1.15-1.25 times as wide as long and approximately 1.7-1.8 times as wide as head. Elytra behind middle of suture with more or less pronounced elevation on either side of suture in both sexes. Abdomen widest at base, gradually tapering posteriad; anterior impressions of tergites III-V not very deep, that of tergite VI shallow; punctation sparse; all tergites without distinct microsculpture; tergite III with weakly pronounced tubercle in both sexes (absent or indistinct in small specimens).

$0^{*}$ : tergite VII with weakly pronounced, smooth, transverse elevation at posterior margin; sternites IV and $\mathrm{V}$ unmodified; median lobe of aedeagus with rather long and slender ventral process (Fig. 34).

: spermatheca as in Fig. 66. 


\section{Distribution and bionomics:}

Aleochara subtumida has been recorded from various localities in Turkey and from the Caucasus region (Russia, Georgia, Azerbaijan) (Assing 2004, 2006b, 2007, FAGEL 1968; material examined) (Map 4). The records of $A$. subtumida and A. lurida from Bolu by FAGEL (1968) are based on misidentifications and refer to $A$. bituberculata and $A$. conviva, respectively. The labels with detailed collection data indicate altitudes of $90-1800 \mathrm{~m}$.

\section{Aleochara (Ceranota) adusta EPPELSHEIM, 1890 (Figs 35-40, 70, 135-137, 141)}

Aleochara (Ceranota) adusta Eppelsheim, 1890a: $163 \mathrm{f}$.

\section{Type material examined:}

Lectotype $\sigma^{\star}$, present designation: Caucasus, Araxesthal, Leder Reitter / Aleochara adusta Epp. / c. Eppelsh. Steind. d. / Typus / Lectotypus ơ Aleochara adusta Eppelsheim desig. V. Assing 2006 / Aleochara adusta Eppelsheim det. V. Assing 2006 (NHMW). Paralectotype + : Caucasus, Araxesthal, Leder Reitter / unicum [following word illegible] / adusta / c. Eppelsh. Steind. d. / adusta Epp. Wien. Ent. Zeit. 1890 p. 163 / Typus (NHMW).

\section{Comment:}

The original description of $A$. adusta is based on two syntypes, a male and a female, from "Araxesthal" (Eppelsheim 1990a), both of which were found in the Eppelsheim collection at the NHMW. The male is designated as the lectotype.

Additional material examined:

Georgia: 1 \% , Likhskiy Khrebet ["Meskisches Gebirge"], leg. Leder (NHMW).

Azerbaijan: $3 \bigcirc^{\star} 0^{\star}$, Lerik, leg. Leder (Reitter) (SDEI, cAss); 1 ㅇ, Ordubad ["Araxesthal"], leg. Leder \& Reitter (HNHM); 1 ㅇ, Lenkoran, 1897, leg. Korb (HNHM).

Iran: $1 \sigma^{*}$ : Gilan, Rudbar County, Elburz mountains, $7 \mathrm{~km} \mathrm{NW}$ Bararu, $36^{\circ} 49^{\prime} \mathrm{N}, 49^{\circ} 38^{\prime} \mathrm{E}$ ], $850 \mathrm{~m}$, sifted, 7.VI.2008, leg. Pütz (cAss).

\section{Redescription:}

Body length 4.7-7.8 mm; habitus as in Fig. 135. Coloration: head blackish; pronotum reddish-brown to blackish-brown; elytra reddish-yellow to reddish, with or without the posterior external angles weakly and more or less extensively infuscate; abdomen dark-brown to blackish, with the apex and the posterior margins of the segments reddish; legs reddish yellow to yellowish brown; antennae brown to blackish-brown, with the basal 2-3 antennomeres yellowish to reddish.

Head distinctly oblong, approximately 1.15 times as long as wide (Fig. 136); punctation moderately dense and moderately fine; interstices much wider than diameter of punctures and with very indistinct microreticulation, shiny; eyes moderately large, as long as postocular region or nearly so; anterior portion of clypeus rather narrowly semi-membranous. Antenna relatively long and slender, antennomeres IV-X gradually and weakly increasing in width; preapical antennomeres weakly transverse, usually less than 1.5 times as wide as long, rarely broader; antennomere XI approximately as long as the combined length of IX-X (Fig. 141).

Pronotum weakly transverse, 1.10-1.25 times as wide as long and approximately 1.50-1.65 times as wide as head, much more strongly narrowed anteriad than posteriad; maximal width slightly behind middle; lateral and posterior margins distinctly convex (Fig. 136); punctation variable, usually as fine as that of head, moderately sparse (with the interstices distinctly wider than dia- 
meter of punctures) to dense (with the interstices on average approximately as wide as punctures), usually denser than that of head; microsculpture indistinct; surface glossy.

Elytra 1.25-1.35 times as wide and at suture approximately 0.9 times as long as pronotum; posterior margin near posterior angle sinuate; punctation dense and moderately granulose, distinctly coarser than that of head and pronotum (Fig. 136). Hind wings fully developed. Metatarsomere I approximately as long as, or longer than the combined length of II-IV.

Abdomen widest at segments III-IV, gradually tapering posteriad (Fig. 137); tergites III-V with deep, tergite VI with shallower anterior impressions; these impressions moderately finely punctate, the remainder of the tergal surfaces with relatively sparse and fine punctation; tergites III-VII without appreciable microsculpture (at most with indistinct traces), tergite VIII with very shallow microsculpture; posterior margin of tergite VII with pronounced palisade fringe; posterior margin of tergite VIII convex, without appreciable sexual dimorphism.

$0^{*}$ : tergite III near posterior margin with smooth, shiny, subcircular, and more or less elevated median tubercle (more pronounced in large than in small male) (Fig. 137); sternites IV and V unmodified; tergite VII unmodified (small male) or with weakly elevated, smooth, transverse elevation at posterior margin; posterior margin of sternite VIII distinctly pointed in the middle; median lobe of aedeagus as in Figs 35-40, 0.60-0.73 mm long; apical internal structures distinctly curved in lateral view.

q : tergite III with or without tubercle; posterior margin of sternite VIII moderately convex; spermathecal capsule with relatively short and broad proximal portion (Fig. 70).

\section{Comparative notes:}

Among its consubgeners, the species is characterised by the following character combination: slender and on average moderately large body, slender and distinctly oblong head, slender antennae, weakly transverse and anteriorly strongly narrowed pronotum, usually bicoloured yellowish to reddish elytra, smooth tubercle on the abdominal tergite III, fine and sparse punctation of the abdomen, aedeagus with ventral process apically broadly rounded in lateral view and with distinctly curved apical internal structures.

\section{Distribution and bionomics:}

The species has been recorded from Azerbaijan, Armenia, Georgia, and Iran, from where it is reported for the first time. The record from Russia (Dagestan) in Smetana (2004) refers to the following species. The specimen from Iran was sifted from leaf litter at an altitude of $850 \mathrm{~m}$ in June.

Aleochara (Ceranota) consors EPPELSHEIM, 1890, revalidated (Figs 41-42, 71, 138 140, 171)

Aleochara (Ceranota) consors Eppelsheim, 1890b: $217 \mathrm{f}$.

\section{Type material examined:}

Lectotype $\sigma^{\star}$, present designation: Daghestan, Leder. Reitter. / Aleochara consors Epp. / = adusta Epp. (minor) / c. Eppelsh. Steind. d. / Typus / Lectotypus ơ Aleochara consors Eppelsheim desig. V. Assing 2006 / Aleochara consors Eppelsheim det. V. Assing 2006 (NHMW). Paralectotype + : Caucasus, Martkopi, Leder, (Reitter.) / consors / = adusta Epp. (minor) / consors Epp. Wien. Ent. Zeit. 1890 p. 217 / c. Eppelsh. Steind. d. / Typus (NHMW). 
Additional material examined:

Azerbaijan: 1 ex., Xanlar "Helenendorf bei Elisabetpol" (NHMW).

Russia: 2 ㅇ ㅇ, "Daghestan", leg. Leder \& Reitter (HNHM).

Locality not specified: 1 ex., "Kaukas. Leder" (cAss).

\section{Comment:}

The original description of $A$. consors, which was published in the same journal and issue as that of $A$. adusta, is based on two "männliche Stücke [...], das eine in Daghestan, das andere bei Martkopi gesammelt" (EPPELSHeim 1890b). An examination of these syntypes, which are deposited in the Eppelsheim collection, revealed that one of them is a female. The male is designated as the lectotype.

Bernhauer (1901) placed $A$. consors in synonymy with $A$. adusta. However, based on the observed differences in the morphology of the aedeagi of the lectotypes of $A$. adusta and $A$. consors, they are here regarded as distinct species and the previously synonymised $A$. consors is revalidated.

\section{Diagnosis:}

Small and slender species, body length 3.8-5.4 mm; habitus as in Fig. 138. In external characters highly similar to $A$. adusta, but distinguished as follows:

Size smaller and body more slender (Figs 138-140). Posterior external angles of the elytra not distinctly infuscate. Eyes clearly shorter than postocular region in dorsal view.

$0^{t}$ : abdominal sternite $\mathrm{V}$ occasionally (lectotype) in the middle with somewhat denser punctation, other secondary sexual characters as in $A$. adusta; median lobe of aedeagus approximately $0.50 \mathrm{~mm}$ long, smaller than in $A$. adusta, ventral process in lateral aspect apically more slender, basally more strongly sinuate, and meeting basal capsule at more acute angle; crista apicalis more pronounced (Figs 41-42).

o : tergite III with weakly elevated median tubercle, similar to that in $\sigma^{*}$; posterior margin of sternite VIII moderately convex; spermatheca with shorter duct (Figs 71, 171).

\section{Distribution and bionomics:}

The species has become known only from Azerbaijan, Georgia, and southwestern Russia (Dagestan).

Aleochara (Ceranota) libanica Eppelsheim, 1889 (Figs 43-44, 72, 142-143)

Aleochara (Ceranota) libanica Eppelsheim, 1889b: $166 \mathrm{f}$.

Type material examined:

Lectotype $\sigma^{\star}$, present designation: Helf Syr. / c. Eppelsh. Steind. d. / Typus / Lectotypus $\sigma^{\star}$ Aleochara libanica Eppelsheim desig. V. Assing 2006 / Aleochara libanica Eppelsheim det. V. Assing 2006 (NHMW). Paralectotype t $^{\star}$ [sic] / Helf Syr. / libanica Fauv. Syria, leg. Helfer / c. Eppelsh. Steind. d. / libanica Epp. Deutsch. ent. Zeit. 1889 p. 166 / Typus (NHMW).

\section{Comment:}

The original description is based on an unspecified number of syntypes collected by "Helfer in Syrien" (EPpelsheim 1889b). 
Additional material examined:

Lebanon: $20^{\star} o^{\star}$, Nabeh Safa, $1000 \mathrm{~m}$, wet moss, V.1966, leg. Fagel (IRSNB); $10^{\star}$, Nabeh Safa, $1000 \mathrm{~m}$, Zistus litter, V.1966, leg. Fagel (IRSNB); $1 \sigma^{\star}$, Ain Zhalta, Jabal el Jaidi, 1750 m, cedar forest, V.1966, leg. Fagel (IRSNB); $10^{\star}$, Kartaba, 1200-1400 m, V.1964, leg. Fagel (IRSNB).

Israel: 1 \%, Nahal Kziv (ca. $10 \mathrm{~km} \mathrm{NE} \mathrm{Nahariyya),} \mathrm{13.V.2000,} \mathrm{leg.} \mathrm{Finkel} \mathrm{(TAU);} 10^{\star}$, same data, but 30.I.1999 (TAU); 1 \% , same data, but 20.II.1999 (TAU); $10^{\star}$, same data, but 6.III.1999 (cAss); 1 ค , Upper Galilee, Ya'ar Baram, $33^{\circ} 02^{\prime} \mathrm{N}, 35^{\circ} 25^{\prime} \mathrm{E}, 670 \mathrm{~m}$, old forest, pitfall, 21.V.2005 (cFel); 1 \% , same data, but 6.II.2006 (cAss); 1 ㅇ, same data, but 8.VI.2005 (cFel).

\section{Diagnosis:}

Body length 4.1-6.0 mm; habitus as in Fig. 142. In external characters similar to A. adusta, but distinguished as follows:

Body on average smaller. Pronotum usually reddish; coloration of elytra variable, uniformly yellowish or posterior angles infuscate.

$\sigma^{*}$ : tergite III as in A. adusta (Fig. 143); tergite VII with weakly pronounced, smooth transverse elevation or (rarely) with pair of tubercles near posterior margin; sternites IV-V unmodified; median lobe of aedeagus $0.50-0.57 \mathrm{~mm}$ long, ventral process shorter in relation to basal bulbus and apically more acute (ventral view) and slender (lateral view); apical internal structures rather short and almost straight (Figs 43-44).

+ : tergite III with weakly elevated tubercle; proximal portion of spermatheca capsule longer than in $A$. adusta (Fig. 72).

\section{Comparative notes:}

Aleochara libanica is distinguished from the similar $A$. adusta and $A$. consors by the usually reddish pronotum, the shape of the median lobe of the aedeagus, as well as by the much longer proximal portion of the spermathecal capsule.

\section{Distribution and bionomics:}

Previously, only the two type specimens from "Syria" and material from several localities in Lebanon reported by FageL (1968) had become known. The species is here reported from Israel for the first time. The above material was collected in January-March and May-June, two specimens with pitfall traps in an old forest at an altitude of $670 \mathrm{~m}$.

\section{Aleochara (Ceranota) sarica sp. n. (Figs 45, 73, 144-147)}

\section{Type material:}

Holotype $\sigma^{\star}$ [teneral]: "Iran, Prov. Mazandaran [IR08-01], Sari County, Mohammadabad, Elburz Mts., N-Slope, NE Sangdeh, 1533 m, 3604'06.6"N, 530' $57.8^{\prime \prime E}$ [recte: $36^{\circ} 04.066^{\prime} \mathrm{N}$, $\left.53^{\circ} 09.578^{\prime} \mathrm{E}\right]$, Fagus forest, leaves debris, sifted, 29.V.2008, leg. A. Pütz / Holotypus ơ Aleochara sarica sp. n., det. V. Assing 2009" (cPüt). Paratypes: $1 \sigma^{\star}, 1$ \% [ o $^{\star}$ teneral]: same data as holotype (cPüt, cAss); 1 क [slightly teneral]: "Iran, Prov. Mazandaran [IR08-01A], Sari County, Mohammabad, Elburz Mts., N-Slope, 2,2 km NE Bendela, 1533 m, 3604'06.6"N, 5309' 57.8"E [recte: $36^{\circ} 04.066^{\prime} \mathrm{N}, 53^{\circ} 09.578^{\prime} \mathrm{E}$ ], Fagus forest, leaves debris, sifted, 30.V.2008, leg. A. Pütz" (cPüt). 


\section{Etymology:}

The specific epithet is derived from the name of the county where the type locality is situated.

\section{Description:}

Body length 4.6-5.8 mm; habitus as in Fig. 144. Coloration: head blackish; pronotum blackishbrown; elytra yellowish, scutellar region and postero-lateral angles diffusely infuscate; abdomen blackish, posterior margins of segments reddish; legs yellowish-brown; antennae dark-brown, with antennomeres I-III reddish.

Head distinctly oblong (Fig. 145), with moderately fine punctation; interstices approximately as wide as diameter of punctures, with shallow to distinct microreticulation composed of distinct meshes (Fig. 146); clypeus anteriorly broadly semi-membranous; eyes approximately as long as postocular region in dorsal view.

Pronotum 1.10-1.15 times as wide as long and approximately 1.4-1.5 times as wide as head, widest approximately in, or slightly behind the middle (Fig. 145); punctation approximately as fine as that of head, but denser; interstices with shallow traces of transverse microsculpture visible only at high magnifications, narrower than diameter of punctures.

Elytra approximately 0.95 times as long as pronotum; punctation dense, much more pronounced than that of head and pronotum, and somewhat granulose (Fig. 145). Hind wings fully developed.

Abdomen distinctly narrower than pronotum, widest at base and gradually tapering posteriad; anterior impressions of tergites III-V moderately deep, finely and very sparsely punctate; tergal surfaces without microsculpture and very glossy (Fig. 147); posterior margin of tergite VII with palisade fringe.

$0^{\star}$ : punctation of whole abdomen fine and very sparse, slightly less sparse on tergites VII and VIII than on anterior tergites; tergite III with glossy, weakly elevated, subcircular median tubercle; tergite VII at posterior margin with indistinct transverse elevation (Fig. 147); anterior sternites unmodified; sternite VIII acutely pointed posteriorly; median lobe of aedeagus shaped as in Fig. 45, 0.48-0.55 mm long.

$\rightarrow$ punctation of whole abdomen fine, less sparse than in male; tergite III with or without smooth median tubercle; spermatheca as in Fig. 73.

\section{Comparative notes:}

Among the species of the $A$. subtumida group, $A$. sarica is characterised particularly by the morphology of the aedeagus. From A. adusta, the only other Ceranota species known from Iran, it is a distinguished by smaller size, the much smaller aedeagus, the shape of the ventral process in lateral view, the straight and smaller apical internal structures of the aedeagus, and the more pronounced microsculpture on the head. It is additionally separated from the similar $A$. libanica by the dark pronotum, the more massive antennae, and the modification of the male tergite VII.

\section{Distribution and bionomics:}

The type locality is situated in the Elburz mountain range, northern Iran. The type specimens were sifted from the leaf litter in a beech forest at an altitude of approximately $1530 \mathrm{~m}$. Three of the specimens are teneral. 
Aleochara (Ceranota) feldmanni sp. n. (Figs 46, 148-150)

\section{Type material:}

Holotype ơ: Afghanistan, Nuristan, W Bar Konar, Capa Dara, 7.VII.2007, leg. C. Reuter / Holotypus ơ Aleochara feldmanni sp. n., det. V. Assing 2009 (cAss).

\section{Etymology:}

The species is dedicated to my friend and colleague Benedikt Feldmann, who already suspected the holotype to represent an undescribed species, also in gratitude for his continuous and reliable cooperation in staphylinid research, as well as for the generous gift of the holotype.

\section{Description:}

Body length $5.6 \mathrm{~mm}$; habitus as in Fig. 148. Coloration: head blackish-brown; pronotum brown with diffusely paler lateral and posterior margins; elytra yellowish, postero-lateral angles diffusely infuscate; abdomen dark-brown, posterior margins of segments reddish; legs yellowish-brown; antennae dark-brown, with antennomeres I-III reddish.

Head with sparse and very fine, barely noticeable punctation; interstices with shallow traces of transverse microsculpture visibly only at high magnifications (100 x), much wider than diameter of punctures; clypeus narrowly membranous anteriorly; eyes large, somewhat longer than postocular region in dorsal view (Fig. 149).

Pronotum 1.17 times as wide as long and nearly 1.5 times as wide as head, widest slightly behind the middle; punctation more distinct and much denser than that of head (Fig. 149); interstices without distinct microsculpture (visible only at magnifications of $>100 \mathrm{x}$ ), narrower than diameter of punctures.

Elytra 0.88 times as long as pronotum; punctation dense and rather fine, but more pronounced than that of pronotum, very weakly granulose (Fig. 149). Hind wings apparently fully developed.

Abdomen distinctly narrower than pronotum, widest at base and gradually tapering posteriad (Fig. 150); anterior impressions of tergites III-V moderately deep, rather coarsely and moderately densely punctate; remainder of tergal surfaces with sparse and fine punctation and without distinct microsculpture; posterior margin of tergite VII with palisade fringe.

$\sigma^{\top}$ : tergites III and VII unmodified (Fig. 150); anterior sternites unmodified; sternite VIII acutely pointed posteriorly; median lobe of aedeagus as in Fig. 46.

i: unknown.

\section{Comparative notes:}

Among the species of the A. subtumida group, A. feldmanni is characterised by moderately coarse and rather dense punctation of the anterior impressions of tergites III-V, and by the morphology of the aedeagus.

\section{Distribution and bionomics:}

The type locality is situated in northeastern Afghanistan, not far from the border with Pakistan. The holotype was collected with a pitfall trap. 


\section{Species of doubtful identity}

\section{Aleochara (Ceranota) lucidula Носннитн, 1860}

Aleochara lucidula Носннuтн, 1860: 585.

\section{Comment:}

The original description is based on an unspecified number of syntypes from "Russie méridionale aux environs de Tschougoueff, au Gouv. de Kharkov" (Носннuтн 1860), today Chuhuyiv [= Chuguyev=Tschugujew; $\left.49^{\circ} 50^{\prime} \mathrm{N}, 36^{\circ} 41^{\prime}\right]$ in eastern Ukraine. For remarks on the accessibility of types from the Hochhuth collection see the section on A. subtumida.

According Bernhauer (1901), A. lucidula is closely related to A. erythroptera, but distinguished from this species by larger and broader body, the more densely and coarsely rugate punctation of the elytra, from $A$. ruficornis by smaller body, the - sometimes extremely - sparse punctation of the anterior impressions of the abdominal tergites III-VI, and from both by different male sexual characters (tergite III with weakly elevated tubercle, tergite VII unmodified). The pronotum is described as having coarse and rather dense punctation. Based on the details given regarding the shape of the pronotum and of the head ("viel breiter als lang"), this species refers to the A. ruficornis group.

According to SMETANA (2004), this species has been reported from Azerbaijan, Georgia, Ukraine, and the Russian South European territory. However, all the specimens previously identified as A. lucidula and examined in the course of the present study refer to other species, particularly to $A$. adusta, suggesting that this species has been misinterpreted and misidentified by previous authors, so that all previous records require confirmation.

\section{Aleochara (Ceranota) bodemeyeri BernaUER, 1914 (Figs 74, 155-156)}

Aleochara (Ceranota) bodemeyeri BeRNHAUER, 1914: 43.

\section{Type material examined:}

Syntype 9 : Asia-Minor, Goek-Dagh, v. Bodemeyer / Bodemeyeri n. sp. Bh. Typ. / Syntypus / Type: Det. Bernhauer / Atheta Bodemeyeri Bernh. / Aleochara Bodemeyeri Bh., Dr. G. Benick det. / coll. DEI Müncheberg / Syntypus Aleochara bodemeyeri Bernh., rev. V. Assing 2009 / Aleochara bodemeyeri Bernhauer, det. V. Assing 2009 (SDEI).

\section{Comment:}

The original description is based on two females from the "Goek-Dagh" in northwestern Anatolia (Bernhauer 1914). One of them was studied, redescribed, and illustrated by Assing (2007). The other syntype was located in the collections of the SDEI (see above).

Based on the shape of the head and the pronotum, this species probably refers to the A. ruficornis group. It is characterised by small body size, slender habitus, uniformly reddish antennae, the oblong head with the eyes slightly shorter than the postocular region, the subparallel abdomen, and the absence of modifications on the female tergite III. The spermatheca, the habitus, and the forebody of the syntype from the SDEI are illustrated in Figs 74, 155-156. For illustrations of the syntype from the Bernhauer collection at the FMNH see Assing (2007). 
Aleochara (Ceranota) ocaleoides (BERNHAUER, 1902)

Amarochara ocaleoides BERNHAUER, 1902: 252.

\section{Comment:}

The holotype of $A$. ocaleoides, a female from Turkey, was studied by Assing (2002), who illustrated the spermatheca. It is characterised by a slender body, a reddish pronotum, apically distinctly incrassate antennae with strongly transverse preapical antennomeres, and a very sparsely punctate abdomen with anterior impressions only on tergites III-V. The species has never been found again.

\section{Aleochara (Ceranota) plicata LOKAY, 1907}

Aleochara (Ceranota) plicata LoKAY, 1907: 78 ff.

\section{Comment:}

The original description is based on two syntypes, a male and a female, from Adana, Turkey. The types were looked for, but not found in the collections of the natural history museum in Prague (FIKÁČEK, pers. comm.), where the Lokay collection is deposited. According to LOKAY (1907), the species is characterised by the coloration (elytra reddish-brown, pronotum brown with paler margins, abdomen black with reddish apex and reddish posterior margins of the anterior segments) and the male secondary sexual characters (tergite III with a large tubercle, tergite IV with a small tubercle posteriorly extending into a sharp keel, this keel continued on tergite V, tergite VII at posterior margin with small tubercle anteriorly extending into a carina, tergite VIII with a carina along middle, posteriorly extending into a short spine). The male sternites IV and V have modified pubescence, so that this species undoubtedly refer to the $A$. ruficornis group. The species has never been recorded again since the original description.

\section{Key to the species of Ceranota}

With few exceptions, a reliable identification of Ceranota females is difficult. At least in material from the southeast of the Western Palaearctic region (Turkey, Caucasus region, probably also Iran and adjacent regions), it is usually impossible. The key does not account for the following doubtful taxa, either because males are unknown or because type material was not available for examination (see comments in the preceding sections): A. bodemeyeri (N-Turkey), A. lucidula (Caucasus region), A. ocaleoides (Turkey), and A. plicata (S-Turkey). For remarks on the intraspecific variation of the secondary sexual characters see the section on taxonomy and identification in chapter 3 .

1. Male sternites IV and V unmodified. Male abdominal tergite III with or without subcircular, smooth median tubercle (Fig. 143); tergites IV-VI unmodified; tergites VII at posterior margin with or without weakly pronounced transverse elevation or pair of tubercles. Head in most species distinctly oblong and 1.10-1.15 times as long as wide. Facies slender. Elytra in most species yellowish, postero-lateral angles often more or less distinctly infuscate. Distribution confined to Turkey, Caucasus region, Iran, Afghanistan. The A. subtumida group. 2 
Male sternites IV and V with more or less pronounced patches with dense long pubescence (Figs 76-103). Male abdominal tergite III often with erect median process; tergite IV often with median tubercle; tergite VII often with pronounced elevation or process at posterior margin. Head approximately as wide as long, at most weakly oblong. Elytra in most species reddish or yellowish-red. The $A$. ruficornis group. 7

2. Elytra slightly behind middle with more or less pronounced elevation on either side of suture (Fig. 134). Pronotum strongly narrowed anteriad (i.e., anterior margin much narrower than posterior margin). Relatively large species, 5.5-8.5 mm. $o^{\text {t }}$ : aedeagus as in Fig. 34. 우: spermatheca as in Fig. 66. Distribution: Caucasus region, Turkey (Map 4).

A. subtumida

Elytra without elevations on either side of suture. Mostly smaller species. 3

3. Male tergites III and VII unmodified. Aedeagus as in Fig. 46. Afghanistan.

A. feldmanni

Male tergite III with - often indistinct - median tubercle and/or tergite VII often with transverse elevation or pair of tubercles at posterior margin. Distribution different. ..... 4

4. Pronotum usually uniformly reddish. Antennae shorter and more slender, weakly incrassate apically; antennomeres IV-X reddish to brown. $\sigma^{\star}$ : tergite III with or without - often very indistinct - tubercle; tergite VII with weakly elevated, smooth transverse elevation or with pair of tubercles at posterior margin; median lobe of aedeagus as in Figs 43-44. + : proximal portion of spermatheca relatively long and slender (Fig. 72). Middle East.

A. libanica

Pronotum usually dark with reddish margins. Antennae longer, with antennomeres IV-XI brown to blackish-brown. $\sigma^{*}$ : tergite III usually with distinct median tuberle; tergite VII usually with (in small males sometimes obsolete) weakly elevated, smooth, transverse elevation at posterior margin; aedeagus of different shape. Species from Caucasus region and Iran. 5

5. Body larger, 4.7-7.8 mm long. $\sigma^{*}$ : tergite III on average with more pronounced tubercle (Fig. 137); tergite VII usually with distinct transverse elevation at posterior margin; median lobe of aedeagus larger, $0.62-0.73 \mathrm{~mm}$ long, ventral process apically broadly rounded in lateral view, apical internal structures strongly curved in lateral view (Figs 35-40). 웅 spermatheca larger and stouter (Fig. 70). Caucasus region, including NW-Iran.

A. adusta

Body smaller, 3.8-5.2 mm long. $\sigma^{\star}$ : tergite III on average with less pronounced tubercle; tergite VII often with indistinct, sometimes obsolete transverse elevation at posterior margin; median lobe of aedeagus smaller, approximately $0.50-0.55 \mathrm{~mm}$ long, ventral process apically more slender and internal structures of different shape. 6

6. $\sigma^{*}$ : median lobe of aedeagus shaped as in Figs 41-42, apical internal structures gently curved. : : proximal portion of spermathecal capsule short and stout (Figs 71, 171). Azerbaijan, Georgia, SW-Russia (Dagestan). A. consors

$\sigma^{\star}$ : median lobe of aedeagus shaped as in Fig. 45, apical internal structures almost straight. : : proximal portion of spermatheca capsule long and slender (Fig. 73). N-Iran. 
7. $\sigma^{\star}$ : abdominal sternites IV and V in most of anterior half with transverse, indistinctly delimited, microsculptured area with long pubescence; this pubescence not conspicuously dense (Figs 76-77, 98-99; Figs 91-92 in Assing 2007; Figs 107-108 in Assing 2009).

$\sigma^{*}$ : abdominal sternites IV and V with well-delimited subcircular, transversely kidneyshaped or oval, often somewhat impressed patches with pronounced microsculpture and conspicuously dense long pubescence (best visible in latero-ventral view). 12

8. Larger species of up to $10.5 \mathrm{~mm}$. $\sigma^{\text {t }}$ : tergite III with strongly elevated median tubercle (small male) or erect median process (large male); tergite IV with more or less pronounced median tubercle; tergite $\mathrm{V}$ rarely (only in very large male) with indistinct smooth and barely elevated median area; median lobe of aedeagus as in Figs 1-3. ㅇ: abdomen with relatively dense and coarse punctation; spermathecal capsule with rather stout and short proximal portion (Fig. 53). Widespread from Balkans and southern Italy to southern Fennoscandia and northern Spain.

A. ruficornis

- Smaller species of up to $7.5 \mathrm{~mm}$. Male tergite III at most with weakly elevated, often indistinct smooth tubercle; tergites IV-V unmodified. Abdomen in both sexes finely and sparsely punctate. Turkey and Caucasus region.

9. Head and pronotum with distinct microsculpture. ................................................. 10

Head and pronotum without - at most with shallow traces of - microsculpture. ......... 11

10. Pronotum larger, approximately 1.30-1.35 times as wide as long (Fig. 117; figure 88 in Assing 2007). Body on average larger, 4.0-5.5 mm. $\sigma^{*}:$ abdominal tergite III posteriorly with distinctly elevated median tubercle (figure 90 in Assing 2007); tergite VII at posterior margin with weakly elevated, smooth transverse ridge or with subcircular tubercle (Fig. 120; figure 90 in Assing 2007); median lobe of aedeagus stout and with short ventral process of characteristic shape (Figs 26-28). Spermatheca similar to that of $A$. libanica (cf. Fig. 72). Caucasus region: SW-Russia, Georgia (Map 4). A. caucasica

- $\quad$ Pronotum more slender, at most 1.25 times as wide as long (Assing 2009: figure 4). Body on average smaller, 3.0-4.9 mm. $\sigma^{*}$ : abdominal tergite III at most with very indistinct smooth elevation (figure 106 in Assing 2009); tergite VII unmodified; median lobe of aedeagus smaller, approximately $0.40 \mathrm{~mm}$ long, and of completely different shape (Figs 49-50). 우 : spermatheca as in Fig. 69. Northeastern Anatolia.

A. simplicicornis

11. Body larger, approximately $6.5 \mathrm{~mm}$ long. Antennae longer and more slender, antennomeres IV oblong and X indistinctly transverse (Fig. 124). Elytra relatively shorter, approximately 0.8 times as long as pronotum (Fig. 123), uniformly bright reddish. Abdomen, particularly tergites VI-VII, with denser and coarser punctation (Fig. 125). $0^{\text {t }}$ : tergite III with distinct median tubercle (Fig. 125); median lobe $0.75 \mathrm{~mm}$ long, of the caucasica type (Fig. 29). W-Caucasus: Adygeya (Map 4).

A. virilis

Body smaller, 4.0-5.5 mm long. Antennae shorter and apically distinctly incrassate; antennomeres IV moderately and V-X strongly transverse (figure 17 in Assing 2007). Elytra longer, 0.90-0.95 times as long as pronotum; dark-yellowish, more or less extensively infuscate in postero-lateral portion. $\sigma^{*}$ : tergite III without distinct median tubercle; median lobe of aedeagus $0.45-0.50 \mathrm{~mm}$ long and of completely different shape (Figs 47-48). 우: spermatheca as in Fig. 68. Central southern Anatolia: Mersin.

A. caloderoides 
12. Clypeus completely semi-membranous (i.e., semi-membranous portion reaching anterior margin of frons), semi-membranous portion approximately half as long as broad (Figs 113115); anterior margin of frons (i.e., the border between the sclerotised and the semi-membranous portion) usually more or less broadly excised. Head more or less distinctly dilated posteriad, usually widest behind eyes, often conspicuously large in relation to pronotum. Eyes situated on dorso-lateral slope of head view (i.e., orientation not vertical, but oblique), broadly visible in dorsal (Figs 113-115).

Posterior portion of clypeus sclerotised and black, anterior semi-membranous portion much less than half as long as broad. Head usually of different shape and eyes situated on sides of head (orientation vertical), narrowly visible in dorsal view (e.g., Figs 104, 127, 152). . ...

13. Whole forebody, including elytra, with conspicuous microsculpture (Fig. 112), conspicuously opaque, dull, and with fine, dense punctation; punctation of elytra almost as fine and indistinct as that of pronotum. Abdomen densely and rather coarsely punctate (Fig. 111). Posterior margin of pronotum somewhat produced in the middle. Pronotum usually completely black. $\sigma^{\star}$ : abdominal tergites III and VII in large male with strongly erect tubercles; aedeagus as in Fig. 19. : : spermatheca as in Fig. 60. Pyrenees, western Alps, Ukraine. ...

A. opacina

Forebody sometimes with microsculpture, but not conspicuously opaque and dull; punctation of pronotum not conspicuously dense; punctation of elytra distinct, coarser than that of pronotum. Abdomen with sparser punctation. Posterior margin of pronotum smoothly and broadly convex. 14

14. Antennae strongly incrassate apically, antennomeres VII-X $>1.5$ times as wide as long. Abdominal tergites III modified in both sexes. $\sigma^{*}$ : median lobe of aedeagus as in Figs 2021. ㅇ: spermatheca as in Figs 61-62. Balkans (Map 3). A. strasseri

Antennae weakly incrassate apically, antennomeres VII-X at most 1.5 times as wide as long. Species from southwestern Europe and Turkey. 15

15. Eyes approximately as long as postocular region in dorsal view. Whole forebody with pronounced microreticulation and distinctly reduced shine. Elytra short, approximately 0.70-0.75 times as long as pronotum (Assing 2007: figure 28). $0^{\star}$ : tergite VII with rather pronounced, smooth transverse ridge at posterior margin (Assing 2007: figures 31, 34); median lobe of aedeagus of rather compact morphology (Figs 23-24). Southwestern Turkey (Antalya).

A. membranosa

- $\quad$ Eyes shorter than postocular region in dorsal view. Forebody with shallow microsculpture and more or less glossy. Elytra of variable length, mostly longer, 0.70-0.95 times as long as pronotum. $\sigma^{t}$ : tergite VII without or with very indistinct transverse tubercle at posterior margin; median lobe of aedeagus with very slender ventral process (Fig. 22). $q$ : spermatheca as in Fig. 63. Southwestern Europe: southern Spain to western Alps (Map 2).

A. hydrocephala

16. Small and slender species, 4.3-5.3 mm (abdomen fully extended) (Assing 2006a: figure 33 ), with wing dimorphism. Hind wings often reduced to short rudiments. Elytra in macropterous morph $0.80-0.85$ times, in micropterous morph approximately 0.7 times as long as pronotum. Whole forebody with distinct microreticulation. Eyes small (Assing 2006a: figure 34 ), distinctly shorter than postocular region in dorsal view. Antenna relatively 
short and distinctly incrassate apically. Abdomen of variable coloration, often extensively reddish. $0^{*}$ : tergite III with small median tubercle (AssING 2006a: figure 35); tergite VII at posterior margin with oblique, smooth, median tubercle of almost triangular shape, in large male produced beyond posterior margin (Assing 2006a: figures36-38); median lobe of aedagus as in Fig. 52. + : spermatheca as in Fig. 75. Greece: Kato Olympos. ....

A. mortuisimilis

Fully winged species. Character combination different. 17

17. Abdominal tergites III-V usually more or less extensively reddish, often with more or less extensive dark median spot, but at least the lateral and anterior margins reddish. Habitus slender. Antennae long and slender, preapical antennomeres as long as wide or only indistinctly transverse. 18

Abdominal tergites III-V blackish, usually with reddish posterior margins. 20

18. Head and pronotum at most with very shallow traces of microsculpture, glossy. $\sigma^{*}$ : tergites III-VI in posterior $2 / 3$ with very sparse punctation; tergite III posteriorly with distinctly erect median tubercle (large male), tergite IV with rather large, smoothly convex median tubercle (large male), tergite $\mathrm{V}$ sometimes in large male with very indistinct indication of smooth median elevation; tergite VII with erect median tuberle at posterior margin (large male); sternites IV and V with rather large subcircular areas with pronounced microsculpture and with conspicuously dense and long pubescence (Figs 82-83); median lobe of aedeagus smaller, approximately $0.7 \mathrm{~mm}$ long, shaped as in Fig. 13. + : spermatheca conspicuously long and slender (Fig. 57). Belgium, France, Germany, Netherlands. A. major

- Head and pronotum with more distinct microsculpture, less glossy. $\sigma^{*}$ : median lobe of aedeagus larger, 0.85-0.95 mm long, and of different shape. + : spermatheca shorter and less slender, proximal portion of capsule relatively shorter. Distribution different.

19. Forebody with shallow microsculpture. $\sigma^{*}$ : anterior impressions of abdominal tergites III-VI with dense punctation; tergite VII at posterior margin with stout, apically acute median tubercle (Fig. 110); median lobe of aedeagus with ventral process of highly distinctive shape, laterally compressed (blade-like) (Fig. 14). Croatia.

A. melichari

Forebody, including elytra, with very distinct microsculpture. $\sigma^{*}$ : anterior impressions of abdominal tergites III-V with very sparse punctation; tergite VII at posterior margin with transverse and in the middle somewhat depressed median elevation; median lobe of aedeagus with ventral process of completely different shape (Figs 15-18). + : abdominal tergites III-V anteriorly with rather dense punctation; spermatheca as in Fig. 58. Alps. Epigeically active during the cold seasons (October to April).

A. penicillata

20. Abdomen mostly with finer and sparser punctation. Body length $<7.5 \mathrm{~mm}$ (abdomen extended). $\sigma^{*}$ : tergites III and VII with small tubercles, VII not with pair of tubercles; tergite IV unmodifed. Species from northern Anatolia and Caucasus region. 21

Abdomen at least with moderately coarse punctation. Body often larger. $\sigma^{\star}$ : tergites III and/or VII in large male with more pronounced tubercle or process, tergite VII sometimes with pair of tubercles; tergite IV often with median tubercle. Distribution different or male abdominal tergite with pair of tubercles at posterior margin. 
21. Pronotum more transverse, 1.30-1.40 times as wide as long (Fig. 127). Abdomen (including the anterior impressions of tergites III-VI) with denser and less fine punctation. $\sigma^{\top}$ : abdominal tergite VII at posterior margin with subcircular median tubercle, near this tubercle and on remainder of posterior half of tergite VII sometimes with additional granula (Figs 129, 154); tergite VIII with or without granulose punctation and often with distinctly serrate posterior margin (Fig. 128); median lobe of aedeagus slender and with very long and slender ventral process (Figs 33, 51). 우 : spermatheca as in Figs 59, 65. Caucasus region, Turkey.

A. conviva

Pronotum less transverse, 1.25-1.30 times as wide as long (Fig. 131). $0^{*}$ : abdominal tergite VII at posterior margin with shortly transverse smooth tubercle, without additional granula (Fig. 133); tergite VIII with non-granulose punctation and with smooth posterior margin; median lobe of aedeagus of compact shape and with much shorter ventral process (Figs 3032). ㅇ: spermatheca as in Fig. 67. Northeastern Anatolia.

A. claviculata

22. Abdominal tergites III, IV, and VII in both sexes modified, without sexual dimorphism; tergite III posteriorly with apically smooth, oblong median tubercle; tergite IV in posterior half with apically acute, weakly elevated longitudinal carina; tergite VII with erect, almost spine-like median process at posterior margin. $\sigma^{*}$ : median lobe of aedeagus as in Fig. 25. o : spermatheca large (Fig. 64). Greece: Pelopónnisos (Map 3).

A. purkynei

Abdominal tergites III, IV, and VII with sexual dimorphism. $\sigma^{\star}$ : tubercle on tergite IV absent or not carinate. $\$$ : spermatheca smaller. Absent from the Pelopónnisos, except A. erythroptera. 23

23. $\sigma^{*}$ : tergite IV in large male with median tubercle (Fig. 105); tergite VII with erect, spinelike median process posteriorly (Fig. 106); median lobe of aedeagus as in Figs 10-12. 우: spermatheca as in Fig. 56. S-France, Spain (Map 2). A. diversicollis

$\sigma^{*}$ : tergite IV unmodified; tergite VII with pair of weakly elevated tubercles at posterior margin (Fig. 166). 24

24. Pronotum reddish to brown. Apex of abdomen (posterior 1/4-1/3 of segment VII; segments VIII-X) bright reddish. $\sigma^{*}$ : tergite III with subcircular to weakly oblong tubercle (Fig. 166); median lobe of aedeagus with relatively short, stout (lateral view), and in ventral view with broad ventral process; apical internal structures massive (Figs 8-9, 167-169). Turkey.

A. bituberculata

Pronotum usually darker, dark-brown to blackish. Apex of abdomen dark-coloured, not sharply contrasting with anterior segments. $0^{*}$ : tergite III usually with oblong, rarely with subcircular median tubercle; aedeagus of different morphology. 25

25. Anterior impressions of tergites III-VI finely and sparsely punctate. $0^{\boldsymbol{x}}$ : middle of posterior margin of tergite VII somewhat elevated, pair of tubercles situated on apex of this elevation; median area of tergite VII with condensed punctation; median lobe of aedeagus larger, shaped as in Figs 6-7. 9 : spermatheca as in Fig. 55. Alps.

A. ganglbaueri

Anterior impressions of tergites III-VI usually moderately coarsely and rather densely punctate (Assing 2007: figure 59). $0^{\star}$ : middle of posterior margin of tergite VII not elevated (Assing 2007: figures 59, 62); tergite VII without condensed punctation in the middle (Assing 2007: figure 59); median lobe of aedeagus smaller and more slender (Figs 4-5). ㅇ: spermatheca as in Fig. 54. Widespread from Turkey to France (Map 1). 


\section{Revised catalogue of the species of Ceranota}

\begin{tabular}{|c|c|c|}
\hline species & distribution & remarks \\
\hline adusta EpPelsheim, 1890 & Azerbaijan, Georgia, Armenia, Iran & \\
\hline bituberculata BernhaUer, 1900 & $\begin{array}{l}\text { Turkey: Sultan Dağları (Isparta/Afyon), } \\
\text { Istanbul, Bolu, Sinop }\end{array}$ & \\
\hline bodemeyeri Bernhauer, 1914 & $\begin{array}{l}\text { Turkey: Kocaeli/Sakaria ("Goek Dagh"), } \\
\text { Bolu }\end{array}$ & male unknown \\
\hline caloderoides Assing, 2007 & Turkey: Mersin & \\
\hline caucasica Eppelsheim, 1889 & W-Caucasus: Georgia, SW-Russia & \\
\hline claviculata sp. $\mathbf{n}$. & NE-Turkey & \\
\hline consors EPPELSHEIM, 1890 & Azerbaijan; Georgia; SW-Russia: Dagestan & \\
\hline conviva Eppelsheim, 1878 & Georgia; Southwest Russia; Turkey: Bolu & \\
\hline diversicollis FAUVEL, 1900 & S-France, Spain & \\
\hline erythroptera GRAVENHORST, 1806 & $\begin{array}{l}\text { Ponto-Mediterranean: Turkey to Spain, } \\
\text { northwards to N-Germany }\end{array}$ & \\
\hline feldmanni sp. n. & NE-Afghanistan & \\
\hline $\begin{array}{l}\text { ganglbaueri BERNHAUER, } 1901 \\
=\text { pacholei } \text { BerNHAUER, } 1928\end{array}$ & $\begin{array}{l}\text { Alps: Austria, Germany, Italy, Slovenia, } \\
\text { Switzerland }\end{array}$ & \\
\hline hydrocephala FAUVEL, 1900 & Spain, France & \\
\hline libanica EpPeLsheIm, 1889 & Middle East: Lebanon, Syria, Israel & \\
\hline lucidula Носннитн, 1860 & Caucasus region; Ukraine & $\begin{array}{l}\text { type material in- } \\
\text { accessible }\end{array}$ \\
\hline major FAIRMAIRE, 1858 & Belgium, France, Germany, Netherlands & \\
\hline melichari (REITTER, 1889) & Croatia & \\
\hline membranosa Assing, 2007 & Turkey: Antalya & \\
\hline mortuisimilis AssING 2006 & Greece: Kato Olympos & \\
\hline ocaleoides (BERNHAUER, 1902) & Turkey & male unknown \\
\hline opacina FAUVEL, 1900 & Pyrenees, Western Alps, Ukraine & \\
\hline $\begin{array}{l}\text { penicillata PeYerimhoff, } 1901 \\
=\text { caprae Gridelli, 1922, syn. } \mathbf{n} . \\
=\text { meschniggi } \text { Bernhauer, } 1943 \text {, syn. } \mathbf{n} .\end{array}$ & $\begin{array}{l}\text { Alps: Austria, SE-France, S-Germany, } \\
\text { N-Italy, Slovenia, Switzerland }\end{array}$ & \\
\hline plicata LOKAY, 1907 & Turkey: Adana & type material lost? \\
\hline purkynei Roubal, 1937 & Greece: Pelopónnisos & \\
\hline $\begin{array}{l}\text { ruficornis GRAVENHORST, } 1802 \\
=\text { daltoni } \text { STEPHENS, } 1832 \\
=\text { grandis }(\text { HEER, 1839) } \\
=\text { laminata }(\text { SCHMIDT-GÖBEL, 1846) } \\
=\text { carolinae } \text { WeNCKER, } 1866 \\
=\text { hummleri } \text { BERNHAUER, } 1914\end{array}$ & $\begin{array}{l}\text { Adriato-Mediterranean: Europe, from } \\
\text { Bosnia-Herzegovina, S-Italy, and N-Spain } \\
\text { to Great Britain, S-Fennoscandia, and } \\
\text { Ukraine }\end{array}$ & \\
\hline sarica sp. n. & Iran: Mazandaran & \\
\hline simplicicornis Assing, 2009 & Turkey: Ordu, Erzurum & \\
\hline $\begin{array}{l}\text { strasseri BERNHAUER, } 1901 \\
=\text { matzenaueri } \text { RAMBOUSEK, 1907, syn. n. }\end{array}$ & $\begin{array}{l}\text { Balkans: Bosnia-Herzegovina, Serbia, } \\
\text { Greece }\end{array}$ & \\
\hline
\end{tabular}




\begin{tabular}{|c|c|c|}
\hline species & distribution & remarks \\
\hline $\begin{array}{l}\text { subtumida }(\text { HochHuth, 1849) } \\
=\text { brunnea }(\text { Motschulsky, 1860) } \\
=\text { lurida } \text { MotsChulsky, } 1860 \\
=\text { reitteri }(\text { Bernhauer, } 1900)\end{array}$ & $\begin{array}{l}\text { Caucasus region: Russian Southwest } \\
\text { European territory, Georgia, Azerbaijan; } \\
\text { Turkey }\end{array}$ & \\
\hline virilis sp. $\mathbf{n}$. & W-Caucasus: Russia (Adygeya) & \\
\hline
\end{tabular}

\section{Species excluded from Ceranota}

\section{Aleochara tuberiventris KRAATZ, 1859 (Figs 157-162)}

Aleochara tuberiventris KRAATZ, 1859: $166 \mathrm{f}$.

\section{Type material examined:}

Syntype $\sigma^{*}$ [dissected prior to present study; considerably damaged: only antennomeres I-V of left antenna and antennomere I of right antennae present, right fore and middle leg, left hind leg, and right metatarsomeres II-V missing]: Ind. post. Helfer / Lectotypus [curator label] / coll. Kraatz / Aleochara tuberiventris / DEI Eberswalde / Aleochara tuberiventris Kr., det. R. Pace 1984, Lectotypus / coll. DEI Müncheberg / Syntypus ơ Aleochara tuberiventris Kraatz, rev. V. Assing 2009 (SDEI).

\section{Comment:}

The original description is based on an unspecified number of syntypes from "India orientali" (KraAtz 1859). One syntype, a male, was located in the Kraatz collection at the SDEI. It has a lectotype label attached to the pin, but I have been unable to trace a published designation.

Aleochara tuberiventris undoubtedly does not refer to Ceranota and is consequently excluded from the subgenus. The modifications of the male abdomen are clearly not homologous to those observed in Ceranota. Also, there are numerous significant characters distinguishing this species from representatives of Ceranota, rendering the possibility highly unlikely that $A$. tuberiventris should represent their adelphotaxon. Thus, if $A$. tuberiventris remained in this subgenus, Ceranota would undoubtedly be polyphyletic.

Aleochara tuberiventris is distinguished from Ceranota as follows: head distinctly transverse; postocular region narrowed posteriad in straight line; eyes very large and bulging, approximately three times as long as postocular region (Fig. 157); antennae with antennomere I with pronounced longitudinal furrow, IV disc-shaped, approximately three times as wide as long, V twice as wide as long (rest of antennae missing); head and pronotum with conspicuously sparse punctation (Fig. 157); male mesotibia apically with conspicuous process (Fig. 161); ventral aspect of male abdomen without modified pubescence; posterior margin of male tergite IV elevated; male abdominal tergite $\mathrm{V}$ with extensive, subcircular median elevation; male sternite $\mathrm{V}$ in latero-posterior angles with pronounced processes projecting posteriad (Figs 158-159); male tergite VIII with pronounced median keel projecting posteriad beyond posterior margin, postero-lateral angles each with distinct tooth-like projection (Fig. 160); median lobe of aedeagus of completely different morphology (Fig. 162); apical lobe of paramere tapering apicad and apically acute. 


\section{Acknowledgements}

My thanks are extended to all the colleagues indicated in the material section for the loan of material under their care. In particular, I am grateful to Benedikt Feldmann for the generous gift of the holotype of $A$. feldmanni and for proof-reading the manuscript, as well as to Michael Schülke for the kind gift of the holotype of $A$. virilis. György Makranczy, Alexey Solodovnikov, and Marc Tronquet assisted in the identification of localities.

\section{References}

AssınG, V. 1994: Zur Kurzflügelkäferfauna xerothermer Flächen im südlichen Niedersachsen (Coleoptera: Staphylinidae). - Göttinger naturkundliche Schriften 3: 7-31.

Assing, V. 1999: A revision of Ilyobates KraAtz, 1856 (Coleoptera: Staphylinidae, Aleocharinae, Oxypodini). - Beiträge zur Entomologie, Berlin 49: 295-342.

Assing, V. 2001a: Kurzflügelkäfer. - In: Hofmeister, H.; Prüss, U.; SPrick, P. \& Weber, U.: Der Steinberg bei Wesseln. Mitteilungen der Paul-Feindt-Stiftung. - Natur und Landschaft im Landkreis Hildesheim, Heft 2: 72-76.

Assing, V. 2001b: A revision of Callicerus Gravenhorst, 1802, Pseudosemiris Machulka, 1935, and Saphocallus Sharp, 1888 (Coleoptera: Staphylinidae, Aleocharinae, Athetini). - Beiträge zur Entomologie, Keltern 51: 247-334.

Assing, V. 2002: A taxonomic and phylogenetic revision of Amarochara Thomson. I. The species of the Holarctic region (Coleoptera: Staphylinidae, Aleocharinae, Oxypodini). - Beiträge zur Entomologie, Keltern 52: 111-204.

Assing, V. 2004: New species and records of Staphylinidae from Turkey II (Insecta: Coleoptera: Staphylinidae) - Beiträge zur Entomologie, Keltern 54: 53-73.

Assing, V. 2006a: New species and records of Staphylinidae from Greece, with two new synonymies (Insecta: Coleoptera). - Linzer biologische Beiträge 38 (1): 333-379.

Assing, V. 2006b: New species and records of Staphylinidae from Turkey IV, with six new synonymies (Coleoptera: Staphylinidae). - Koleopterologische Rundschau 76: 223-276.

Assing, V. 2007: On the Aleocharini of Turkey, with notes on some species from adjacent regions (Coleoptera: Staphylinidae, Aleocharinae). - Beiträge zur Entomologie, Keltern 57 (1): 177-209.

Assing, V. 2009: On the Staphylinidae of Turkey. VI. Thirteen new species and additional records (Coleoptera). - Koleopterologische Rundschau 79: 117-172.

Assing, V. \& Wunderle, P. 2001: On the Staphylinidae of Greece. II. New species and new records from central and northern Greece (Insecta: Coleoptera). - Linzer biologische Beiträge 33: 103-136.

Assing, V. \& Wunderle, P. 2008: On the Alevonota species of the Western Palaearctic region (Coleoptera: Staphylinidae: Aleocharinae: Athetini). - Beiträge zur Entomologie, Keltern 58: 145-189.

Bernhauer, M. 1900: Neue Staphyliniden (Coleoptera) aus dem Kaukasus und den angrenzenden Ländern. - Wiener Entomologische Zeitung 19: 46-55.

Bernhauer, M. 1901: Die Staphyliniden der paläarktischen Fauna. - Verhandlungen der Kaiserlich-Königlichen Zoologisch-Botanischen Gesellschaft in Wien 51: 430-506.

Bernhauer, M. 1902: Die Staphyliniden der paläarktischen Fauna. I. Tribus: Aleocharini. (II. Theil.). Verhandlungen der Kaiserlich-Königlichen Zoologisch-Botanischen Gesellschaft in Wien 52: 87-284.

Bernhauer, M. 1914: Beiträge zur Kenntnis der paläarktischen Staphyliniden-Fauna. - Münchener Koleopterologische Zeitschrift 4: 33-45.

Bernhauer, M. 1928: Neue Staphyliniden der palaearktischen Fauna. - Koleopterologische Rundschau 14: 8-23.

Bernhauer, M. 1943: Neuheiten der palaearktishen Staphylinidenfauna. - Mitteilungen der Münchner Entomologischen Gesellschaft 33: 169-188.

Bernhauer, M. \& O. Scheerpeltz 1926: Staphylinidae VI. - In: Junk, W. \& Schenkling, S. (eds.): Coleopterorum Catalogus, pars 82. - Berlin: 499-988. 
BickHARDT, H. 1907: Käfer in Nestern. - Entomologische Blätter 3: 1-11.

Brenner, U. 1993: Beitrag zur Kenntnis der Käferfauna auf den Halbtrockenrasen der Eifel (Ins., Col.). - Mitteilungen der Arbeitsgemeinschaft Rheinischer Koleopterologen (Bonn) 3 (4): 135-159.

Brenner, U. 1996: Zur Käferfauna des Rosenberges, eines Moselhanges bei Kail (Coleoptera). - Mitteilungen der Arbeitsgemeinschaft Rheinischer Koleopterologen (Bonn) 6 (2): 67-82.

Dvořák, M. 1965: Interessante Funde einiger Staphyliniden-Arten aus der Slowakei (Coleoptera, Staphylinidae). - Acta Rerum Naturalium Musei Nationalis Slovaci, Bratislava 11: 88-92.

Dvǒ̌ák, M. 1967: Interessante Funde der Staphyliniden-Arten aus der Slowakei II (Coleoptera, Staphylinidae). - Acta Rerum Naturalium Musei Nationalis Slovaci, Bratislava 13: 81-88.

Eppelsheim, E. 1878: Staphylinidae. - In: Scheider, O. \& Leder, H.: Beiträge zur Kenntniss der kaukasischen Käferfauna.. - Verhandlungen des naturforschenden Vereines in Brünn 16 (1877): 90-131.

Eppelsheim, E. 1889a: Neue Staphylinen aus den Kaukasusländern, besonders aus Circassien. - Wiener Entomologische Zeitung 8: 11-22.

Eppelsheim, E. 1889b: Neue Staphylinen Europa's und der angrenzenden Länder. - Deutsche Entomologische Zeitschrift 33: 161-183.

Eppelsheim, E. 1890a: Neue Staphylinen aus den Kaukasusländern. - Wiener Entomologische Zeitung 9: 161-172.

Eppelsheim, E. 1890b: Neue Staphylinen aus den Kaukasusländern. - Wiener Entomologische Zeitung 9: 217-229.

Erbeling, L. \& Drees, M. 1992: Die Käferfauna des Kalkhalbtrockenrasens auf dem Kupferberg in Iserlohn-Letmathe (Märkischer Kreis). - Decheniana (Bonn) 145: 93-107.

Ermisch, K. \& Langer, W. 1933: Ueber die Käfergäste im Winterlager des Maulwurfs, zugleich ein Beitrag zur Käferfauna des Vogtlandes. - Koleopterologische Rundschau 19: 16-24.

Eyre, M. D.; Luff, M. L. \& LotT, D. A. 2000: Records of rare and notable beetles species from riverine sediments in Scotland and northern England. - The Coleopterist 9: 25-38.

FAGEL, G. 1968: Contribution à la connaissance des Staphylinidae. CVI. Remarques diverses sur des espèces de la région paléarctique occidentale. - Bulletin et Annales de la Société Royale d'Entomologie de Belgique 104: 189-204.

Fairmaire, L. 1858: Miscellanea Entomologica. Deuxième partie. - Annales de la Société Entomologique de France (3) 5 (1857): 725-745.

Fauvel, A. 1900: Staphylinides paléarctiques nouveaux. - Revue d'Entomologie 19: 218-253.

Feldmann, B. \& Lückmann, J. 1998: Zur Staphylinidenfauna (Coleoptera) der Kalkmagerrasen im Raum Marsberg. - Mitteilungen der Arbeitsgemeinschaft Rheinischer Koleopterologen (Bonn) 8: 73-100.

Gamarra, P. \& Outerelo, R. 2005: Catálogo iberobalear de los Aleocharinae (Coleoptera: Staphylinidae). - Boletín Sociedad Entomológica Aragonesa 37: 1-81.

Ganglbauer, L. 1895: Die Käfer von Mitteleuropa. 2. Band: Staphylinidae und Pselaphidae. - Wien, Carl Gerold's Sohn: 850 pp.

Gravenhorst, J. L. C. 1802: Coleoptera microptera Brunsvicensia. - Brunsuigae, 206 pp.

Gravenhorst, J. L. C. 1806: Monographia Coleopterorum Micropterorum. - Göttingen: 236 pp.

Gravenhorst, J. L. C. 1832: Das zoologische Museum der Universität Breslau. - Breslau, Grass, Barth und Comp.: 188 pp.

Gridelli, E. 1922: Descrizioni di alcuni nuovi Staphylinidae paleartici. - Bollettino della Società Entomologica Italiana 54: 21-28.

Grundmann, B. \& Erbeling, L. 1992: Zur Käferfauna des Naturschutzgebietes Bommecketal in Plettenberg (Märkischer Kreis, Sauerland). - Abhandlungen aus dem Westfälischen Museum für Naturkunde 54 (2): $1-30$.

Hansen, M. 1996: Katalog over Danmarks biller. - Entomologiske Meddelelser 64 (1\&2): 1-231. 
Hansen, M.; Liljehult, H.; Mahler, V. \& Pedersen, J. 1995: 14. tillæg til 'Fortegnelse over Danmarks biller' (Coleoptera). - Entomologiske Meddelelser 63: 21-50.

Hansen, M.; Mahler, V.; Pritzl, G. \& Runge, J. B. 1994: 13. tillæg til 'Fortegnelse over Danmarks biller' (Coleoptera). - Entomologiske Meddelelser 62: 65-89.

HavelKa, J. 1964: Př́íspěvek k poznání slovenska, 1. Část. - Acta Rerum Naturalium Musei Nationalis Slovaci, Bratislava 10: 66-123.

Heiss, E. 1971: Nachtrag zur Käferfauna Nordtirols. - Alpin-Biologische Studien 4, Veröffentlichungen der Universität Innsbruck 67: 1-178.

Hосннuтн, J. H. 1849: Die Staphylinen-Fauna des Kaukasus und Transkaukasiens. - Bulletin de la Société Impériale des Naturalistes de Moscou 22 (1): 18-214.

Hochнuth, J. H. 1860: [description of new species], p. 585. - In: Motschulsky, V. DE (1860): Énumération des nouvelles espèces de coléoptères rapportées de ses voyages. 3-ième article. - Bulletin de la Société Impériale des Naturalistes de Moscou 33: 539-588.

Horion, A. 1967: Faunistik der mitteleuropäischen Käfer. Bd. XI: Staphylinidae, 3. Teil: Habrocerinae bis Aleocharinae (ohne Subtribus Athetae). - Überlingen-Bodensee: 419 pp.

Horn, W.; Kahle, I.; Friese, G. \& Gaedike, R. 1990: Collectiones entomologicae. Ein Kompendium über den Verbleib entomologischer Sammlungen der Welt bis 1960. - Akademie der Landwirtschaftswissenschaften der Deutschen Demokratischen Republik, Berlin: 573 pp.

Ieniştea, M.-A. \& Fabritius, K.: Die Aleocharen (Coleoptera, Staphylinoiden [sic]) Rumäniens, unter besonderer Berücksichtigung der aus Fliegenpuparien gezüchteten Arten. - Entomologische Blätter 78: 20-30.

Ihssen, G. 1935: Beiträge zur Kenntnis der Fauna von Südbayern. (3) (Fortsetzung). - Entomologische Blätter 31: 11-24.

JARRIGE, J. 1968: Sur quelques Brachélytres des Alpes méridionales. - L'Entomologiste 24 (3): 73-79.

Jung, M. 2001: Coleopterologische Neu- und Wiederfunde in Sachsen-Anhalt. - Entomologische Nachrichten und Berichte 45: 37-46.

Junker, M. 2001: Die Käferfauna (Coleoptera) der Grafschafter Krautfabrik in Meckenheim/Rheinland. - Mitteilungen der Arbeitsgemeinschaft Rheinischer Koleopterologen (Bonn) 11: 73-103.

JANÁK, J. 1993: Interessante Funde der Kurzflügler aus Mähren und aus der Slowakei (Coleoptera: Staphylinidae). - Klapalekiana 29: 1-17.

Kahlen, M. 1987: Nachtrag zur Käferfauna Tirols. - Beilageband 3 zu den Veröffentlichungen des Museum Ferdinandeum, Innsbruck: 288 pp.

Klimaszewski, J. 1984: A revision of the genus Aleochara Gravenhorst of America north of Mexico (Coleoptera: Staphylinidae, Aleocharinae). - Memoirs of the Entomological Society of Canada 129: $1-211$.

Косн, K. 1968: Käferfauna der Rheinprovinz. - Decheniana (Bonn), Beiheft 13: 1-382.

Kocian, M. 1993: The staphylinid beetles of Prague (Coleoptera: Staphylinidae). - Klapalekiana 29: 91-98.

KöHLER, F. 1996: Zur Käferfauna (Col.) des unteren Saartales und des westlichen Mosel-Saar-Raumes. Erste Ergebnisse der Pfingstexkursion der Arbeitsgemeinschaft Rheinischer Koleopterologen nach Taben-Rodt vom 6. bis 9. Juni 1996. - Mitteilungen der Arbeitsgemeinschaft Rheinischer Koleopterologen (Bonn) 6: 217-246.

KöHLER, F. 1998: Anmerkungen zur Käferfauna der Rheinprovinz XII. - Mitteilungen der Arbeitsgemeinschaft Rheinischer Koleopterologen (Bonn) 8: 35-51.

Köhler, F. \& Stumpf, T. 1992: Die Käfer der Wahner Heide in der Niederrheinischen Bucht bei Köln (Insecta: Coleoptera). Fauna und Artengemeinschaften, Veränderungen und Schutzmaßnahmen. Decheniana (Bonn) Beiheft 31: 499-593.

Kofler, A. 1980: Fünfter Beitrag zur Käferfauna des Lechtales (Tirol: Österreich) (Insecta: Coleoptera). - Berichte des naturwissenschaftlich-medizinischen Vereins in Innsbruck 67: 117-136. 
Kopetz, A. \& Weigel, A. 2006: Bemerkenswerte Käferfunde in Thüringen aus den Jahren 2004 bis 2006 und Ergänzungen aus den Vorjahren (Insecta, Coleoptera). - Thüringer Faunistische Abhandlungen 9: 97-122.

Korge, H. 1965: Beiträge zur Kenntnis der märkischen Koleopterenfauna (Teil XXVIII.) - Mitteilungen der Deutschen Entomologischen Gesellschaft 24: 33-38.

Kunze, M. \& KaChE, P. 1998: Zonationszönosen von Kurzflügelkäfern (Coleoptera, Staphylinidae) an Flußufern Nordwestdeutschlands. - Zeitschrift für Ökologie und Naturschutz 7: 29-43.

KraAtz, G. 1859: Die Staphylinen-Fauna von Ostindien, insbesondere der Insel Ceylan. - Archiv für Naturgeschichte 25: 1-196.

Lıкоvsкx́, Z. 1968: Bemerkenswerte Aleocharinen-Arten aus der [sic] Sammlungen des Kreismuseum in Hradec Králové (Coleoptera, Staphylinidae) I. (Coleoptera, Staphylinidae). - Acta Musei Reginaehradecensis S. A.: Scientiae Naturales 9: 81-91.

LikovsкÝ, Z. 1973: Bemerkungen über die Gattung Aleochara Gravenhorst (Coleoptera, Staphylinidae). - Annotationes zoologicae et botanicae 71: 1-8.

Likovskx́, Z. 1974: Gattung Aleochara. - In: Freude, H., Harde, K. W. \& G. A. Lohse (eds.): Die Käfer Mitteleuropas, Band 5. - Krefeld, Goecke \& Evers: 293-304.

LıкоvsкÝ, Z. 1982: Über einige Aleochara-Arten aus der Schweiz (Coleoptera, Staphylinidae). - Revue suisse de Zoologie 89: 663-665.

Linke, M. 1907: Verzeichnis der in der Umgebung von Leipzig beobachteten Staphyliniden. - Sitzungsberichte der Naturforschenden Gesellschaft zu Leipzig 1906-1907: 1-54.

Lohse, G. A. 1967: Die Aleocharini (s. lat.) des Niederelbegebietes und Schleswig-Holsteins (Coleoptera, Staphylinidae). - Verhandlungen des Vereins für Naturwissenschaftliche Heimatforschung Hamburg 36: 39-50.

LoKaY, E. 1907: Nová Aleochara z podrodu Ceranota. STEph. - Časopis České Společnosti Entomologické 4: 78-80.

Lupi, D.; Colombo, M. \& Zanetri, A. 2006: Rove beetles (Coleoptera, Staphylinidae) of three horticultural farms in Lombardy (Northern Italy). - Bollettino di Zoologia agraria e di Bachicoltura, Ser. II, 38: 143-165.

Majzlan, O. \& Jászay, T. 1997: Taxocenózy drobčíkov (Coleoptera, Staphylinidae) v pôde lužných lesov rieky Moravy. - Folia faunistica Slovaka 2: 61-69.

MARZo, L. DE 2007: Aspetti morfologici della spermateca in Diestota guadalupensis PACE e altre Aleocharinae (Coleoptera Staphylindiae). - Entomologica, Bari 40 (2006-2007): 57-73.

Maus, C.; Mittmann, B. \& Peschke, K. 1998: Host records of parasitoid Aleochara Gravenhorst species (Coleoptera, Staphylinidae) attacking puparia of cyclorrhapheous Diptera. - Mitteilungen aus dem Museum für Naturkunde zu Berlin, Deutsche entomologische Zeitschrift 45: 231-254.

Molenda, R. 1996: Zoogeographische Bedeutung Kaltluft erzeugender Blockhalden im außeralpinen Mitteleuropa: Untersuchungen an Arthropoda, insbesondere Coleoptera. - Verhandlungen des naturwissenschaftlichen Vereins Hamburg (Neue Folge) 35: 5-93.

Motschulsky, V. DE 1860: Énumération des nouvelles espèces de coléoptères rapportées de ses voyages. 3ième article. - Bulletin de la Société Impériale des Naturalistes de Moscou 33: 539-588.

MüLleR, A. J. 1926: Nachtrag zum Verzeichnis der Käfer Vorarlbergs. - Vierteljahrsschrift für Geschichte und Landeskunde Vorarlbergs 9-10: 1-167.

Mulsant E. \& Rey C. 1874: Tribu des Brévipennes. Famille des Aléochariens - suite - sixième branche. Aléocharaires. - Annales de la Société Linnéenne de Lyon 20: 287-447.

Outerelo, R. 1980: Los Staphylinoidea de la Sierra de Cazorla. - In: Viedma M. G. de (ed.): Fauna de Cazorla. Invertebrados. - Ministerio de Agricultura, Instituto Nacional para la Conservacion de la Naturaleza, Monografias 23: 53-71. 
Peez, A. v. \& Kahlen, M. 1977: Die Käfer von Südtirol. Faunistisches Verzeichnis der aus der Provinz Bozen bisher bekanntgewordenen Koleopteren. - Beilageband 2 zu den Veröffentlichungen des Museum Ferdinandeum, Innsbruck: 525 pp.

Peyerimhoff, P. DE 1901: Description d'un nouveau staphylinide de la Haute-Provence (Aleochara [Ceranota] penicillata, n. sp.) [Col.]. - Bulletin de la Société Entomologique de France 1901: 347-348.

Peyerimhoff, P. de \& Sainte-Claire Deville, J. 1901: Coléoptères nouveaux ou peu connus. - L'Abeille 30: 53-72.

Rambousek F. J. 1907: Popis dvou nových Staphylinidú. - Časopis České Společnosti Entomologické 4: 15-19.

Renner, K. 2001: Coleoptera Westfalica: Familia Staphylinidae, Subfamilia Aleocharinae). - Abhandlungen aus dem Westfälischen Museum für Naturkunde 63 (5): 1-214.

Roubal, J. 1937: Beschreibung einer neuen Aleochara: Ceranota Purkynei n. nebst einer systematischen Tabelle der bekannten paläarktischen Ceranoten und einer Betrachtung über ihre ökologischen Verhältnisse. - Festschrift zum 60. Geburtstage von Professor Dr. Embrik Strand 3: 329-334.

Reitter, E. 1889: Neue Coleopteren aus Europa, den angrenzenden Ländern und Sibirien, mit Bemerkungen über bekannte Arten. Neunter Theil. - Deutsche Entomologische Zeitschrift 1889: 369-376.

Schaffrath, U. 1999: Zur Käferfauna am Edersee (Insecta, Coleoptera). - Philippia 9: 1-94.

Schatz, I. 2006: Bermerkenswerte Kurzflügelkäfer (Coleoptera: Staphylinidae) der Illauen (Vorarlberg, Österreich). - Berichte des naturwissenschaftlich-medizinischen Vereins in Innsbruck 93: 85-105.

Schatz, I. 2008: Kurzflügelkäfer (Coleoptera: Staphylinidae) im Naturpark Schlern - Rosengarten (Südtirol, Italien). - Gredleriana 8: 377-410.

Schatz, I.; Kopf, T.; Steinberger, K.-H. \& Glaser, F. 2003: Die Kurzflügelkäfer (Coleoptera, Staphylinidae) des Frastanzer Riedes und der angrenzenden Illaue (Vorarlberg, Österreich). - Voralberger Naturschau 13: 239-258.

Schmaus, M. 1969: Zur Koleopterenfauna des Hunsrücks. 6. Beitrag. - Entomologische Blätter 65: 154-159.

Schmidt-Göвel, H. M. 1846: Ein neues Genus aus der Familie der Staphylinen. - Entomologische Zeitung (Stettin) 7: 245-248.

Scholze, P. \& Jung, M. 1994: Beiträge zur Faunistik der Kurzflügler (Coleoptera, Staphylinidae) im Nordharz und Vorland II. Unterfamilie Aleocharinae. - Entomologische Nachrichten und Berichte 38: 7-12.

Segers, R. 1986: Catalogus Staphylinidarum Belgicae (Coleoptera) - Institut Royal des Sciences Naturelles de Belgique, Documents de Travail 32: 1-104.

Smetana, A. 1954: Systematické a faunistické poznámky ke zvíreně drabíků Československa. - Acta Societatis entomologicae Cechosloveniae 51: 135-148.

Smetana, A. 2004: Staphylinidae, subfamily Aleocharinae, pp. 353-494. - In: Löbl, I. \& Smetana, A. (eds.): Catalogue of Palaearctic Coleoptera. II. Hydrophiloidea - Histeroidea - Staphylinoidea. - Stenstrup, Apollo Books: 942 pp.

Staniec, B. 1992: Nowe stanowiska niektórych gatunków z rodzaju Aleochara Gravenhorst (Coleoptera, Staphylinidae) w Polsce. - Wiadomości Entomologiczne 11: 124.

Staniec, B. 1996: Materiały do poznania kusakowatych (Coleoptera, Staphylinidae) Wyżyny Lubelskiej. Część II. - Wiadomości Entomologiczne 15: 23-29.

Stephens, J. F. 1839: A manual of British Coleoptera, or beetles; containing a brief description of all the species of beetles hitherto ascertained to inhabit Great Britain and Ireland; together with a notice of their chief localities, times and places of appearances, etc. - London, Longman, Orme, Brown, Green, and Lomans: xii +443 pp.

Tronquet, M. 2006: Catalogue iconographique des coléoptères des Pyrénées-Orientales. Volume I (édition revue et augmentée). Staphylinidae. - Revue de l'Association Roussillonnaise d'Entomologie 15 (Supplément): 1-127 + 78 plates. 
Uhuig, M. \& Vogel, J. 1981: Zur Staphylinidenfauna der Umgebung von Waren/Müritz (Mecklenburg). - Mitteilungen des zoologischen Museums Berlin 57: 75-168.

Vogel, J. 1982: Ökofaunistische Untersuchungen an der Staphylinidenfauna des Hakelwaldes im Bezirk Halle/S. (DDR). - Hercynia, Neue Folge, Leipzig 19: 146-170.

Vogel, J. 1998: Gattung Aleochara Gravenhorst. U.G. Ceranota. Bestimmungstabelle der mitteleuropäischen Arten. - In: Lucht, W. \& Klausnitzer, B. (eds.): Die Käfer Mitteleuropas. 4. Supplementband. - Jena, Stuttgart, Lübeck, Ulm, G. Fischer Verl.: 195-197.

Vogel, J. \& Dunger, W. 1980: Untersuchungen über Struktur und Herkunft der Staphyliniden-Fauna (Coleoptera, Staphylinidae) einer Rasen-Wald-Catena in Thüringen (Leutratal bei Jena). - Abhandlungen und Berichte des Naturkundemuseums Görlitz 53 (3): 1-48.

Vogel, J. \& Dunger, W. 1991: Carabiden und Staphyliniden als Besiedler rekultivierter Tagebau-Halden in Ostdeutschland. - Abhandlungen und Berichte des Naturkundemuseums Görlitz 65: 1-31.

Welch, R. C. 1997: The British species of the genus Aleochara Gravenhorst (Staphylinidae). - The Coleopterist 6 (1): 1-48.

Wörndle, A. 1950: Die Käfer von Nordtirol. - Schlern-Schriften, Bd. 54, Innsbruck: 388 pp.

ZanetTI, A. 1995: Habrocerinae, Trichophyinae, Tachyporinae e Aleocharinae (generi 148-314), pp. 33-58. - In: Ciceroni, A., Puthz, V. \& Zanetti, A.: Coleoptera, Polyphaga III (Staphylinidae). Checklist delle specie della fauna italiana. - Calderini Bologna, Fasc. 48: 1-65.

Zerche, L. 1980: Faunistisch interessante Staphylinidae aus der DDR (Coleoptera). - Entomologische Nachrichten 24: 145-165.

Author's address:

Dr. Volker Assing

Gabelsbergerstr. 2

30163 Hannover

Germany

e-mail: vassing.hann@t-online.de
Subject Editor:

Dr. L. Zerche 

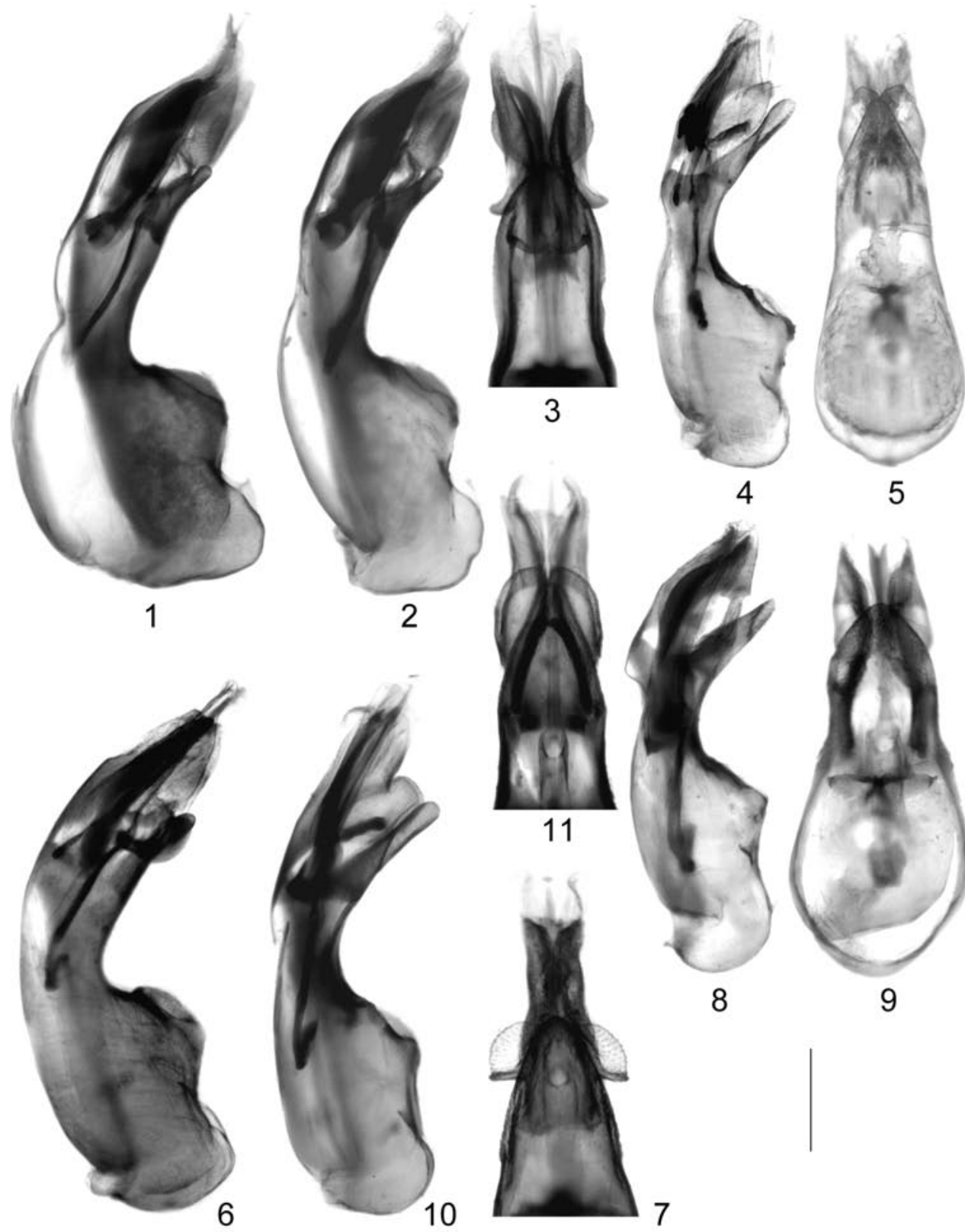

4

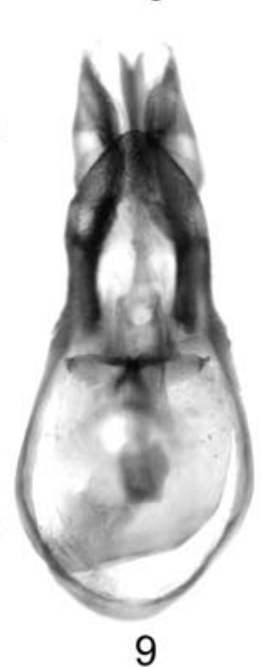

Figs 1-11: Aleochara ruficornis (1-3; Germany), A. erythroptera (4-5; Germany), A. ganglbaueri (6-7; Austria), A. bituberculata (8-9; holotype), and A. diversicollis (10-11; Spain): median lobe of aedeagus in lateral view $(1-2,4,6,8,10)$; apical portion of median lobe of aedeagus in ventral view $(3,7,11)$; median lobe of aedeagus in ventral view $(5,9)$. Scale bar: $0.2 \mathrm{~mm}$. 


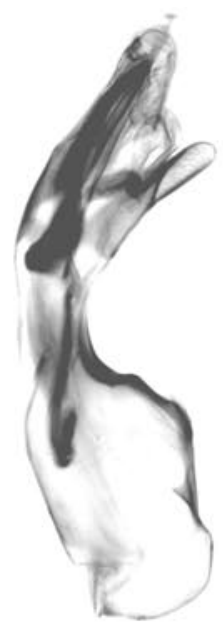

12

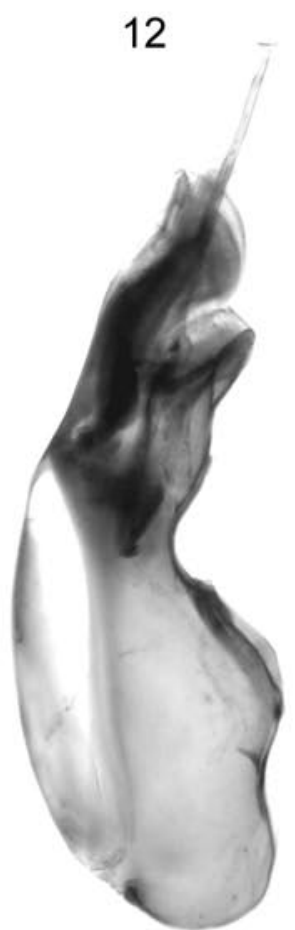

15

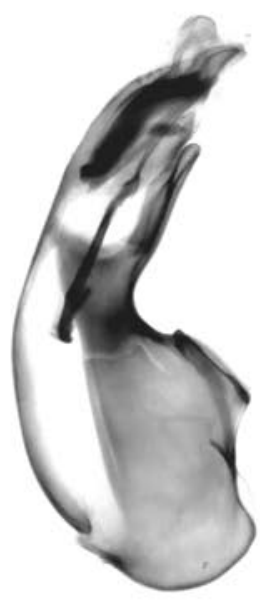

13
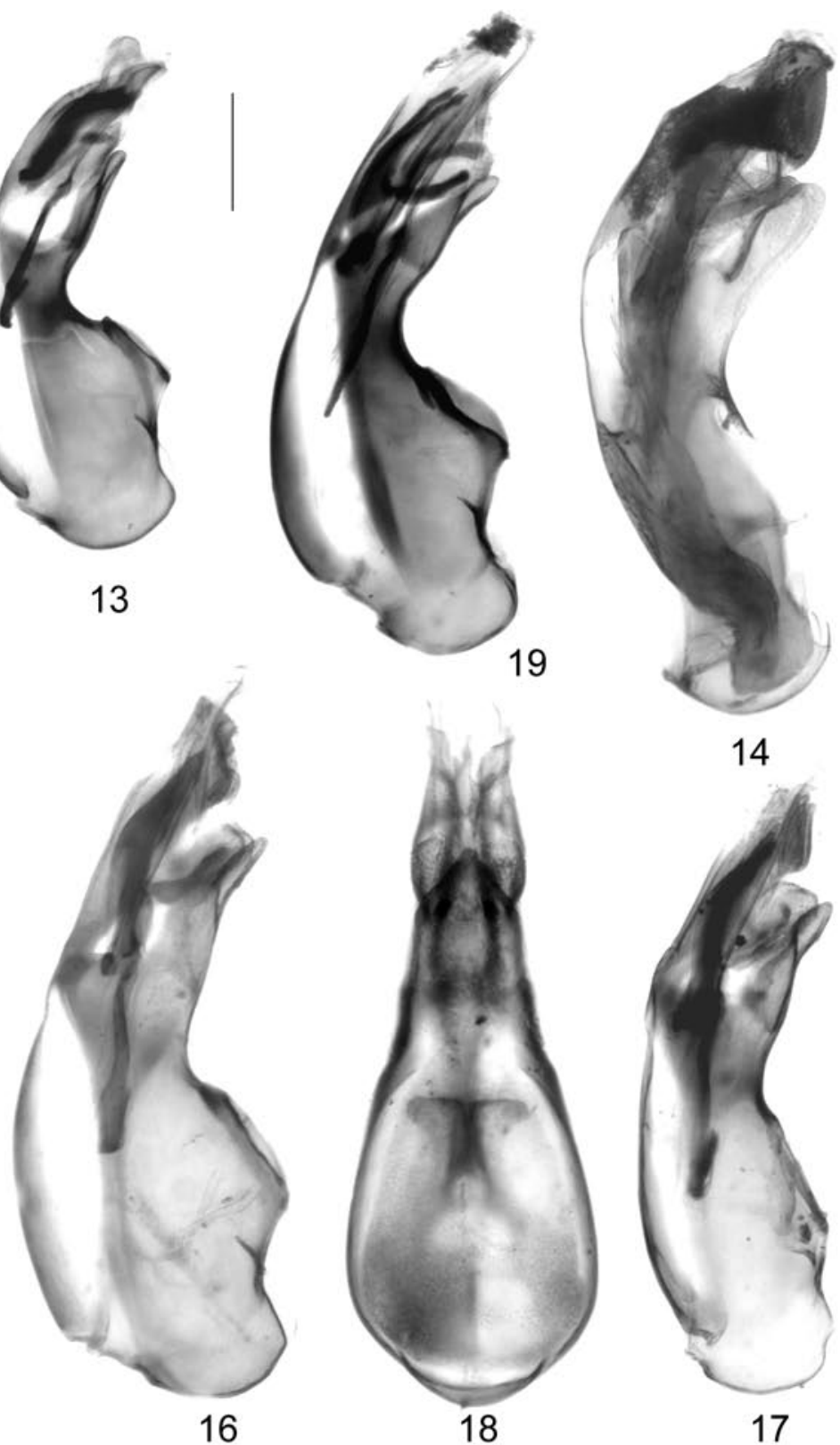

Figs 12-19: Aleochara diversicollis (12; lectotype), A. major (13; Germany), A. melichari (14; paralectotype), A. penicillata (15-18; 15: S-Germany; 16, 18: Austria; 17: holotype), and A. opacina (19; SE-France): median lobe of aedeagus in lateral view $(12-17,19)$; median lobe of aedeagus in ventral view (18). Scale bar: $0.2 \mathrm{~mm}$. 

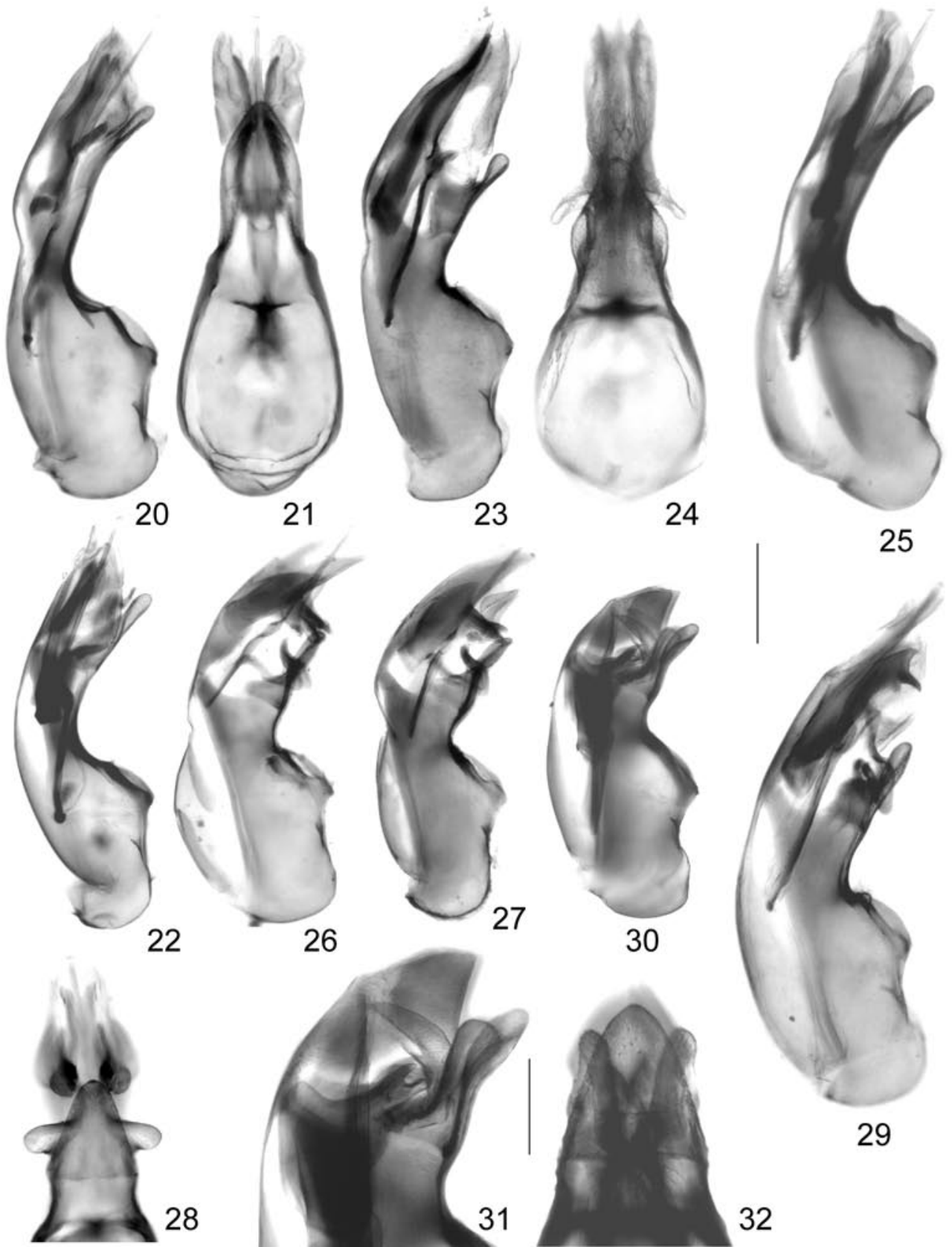

Figs 20-32: Aleochara strasseri (20-21; Bosnia-Herzegovina), A. hydrocephala (22; Spain), A. membranosa (23-24; holotype), A. purkynei (25; Greece), A. caucasica (26-28; 26, 28: holotype; 27: Georgia), A. virilis (29; holotype), and $A$. claviculata (30-32; holotype): median lobe of aedeagus in lateral view (20, 22-23, 25-27, 29-30); median lobe of aedeagus in ventral view $(21,24)$; apical portion of median lobe in ventral and in lateral view $(28,31-32)$. Scale bars: $20-30: 0.2 \mathrm{~mm}$; 31-32: $0.1 \mathrm{~mm}$. 


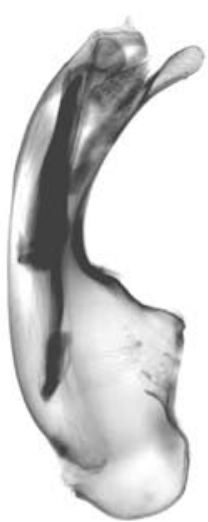

33
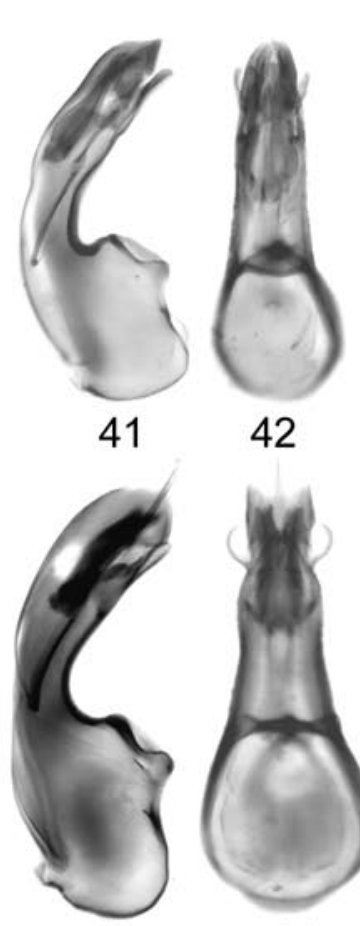

43

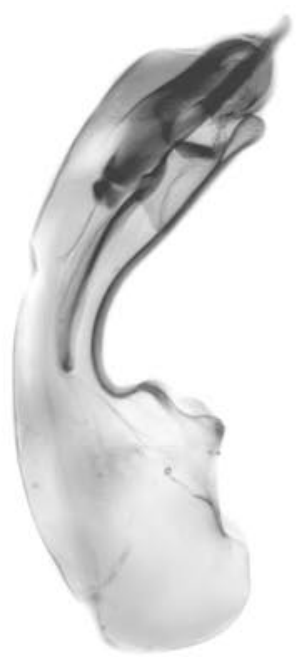

34

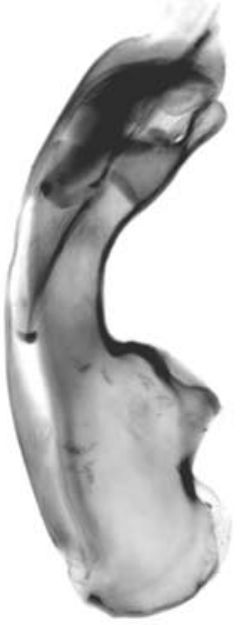

37

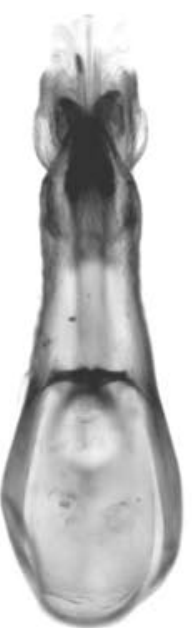

38

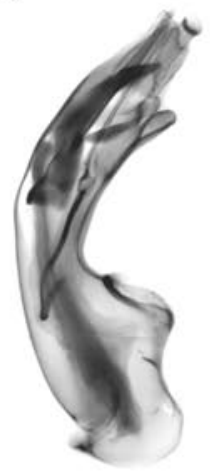

46

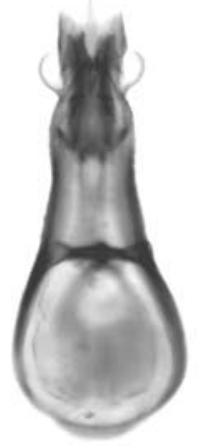

44

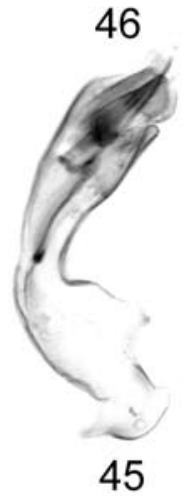

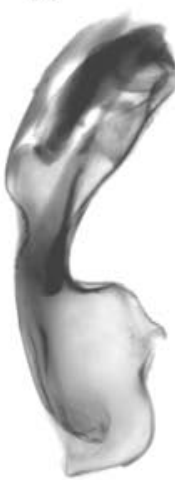

35

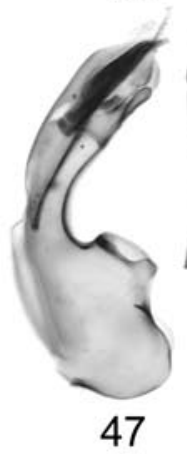

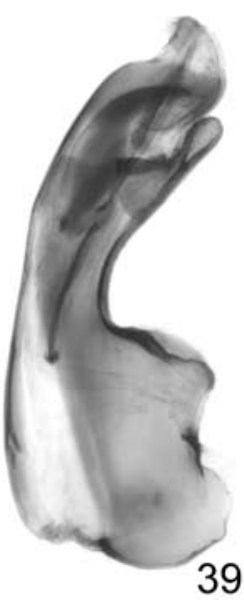

39

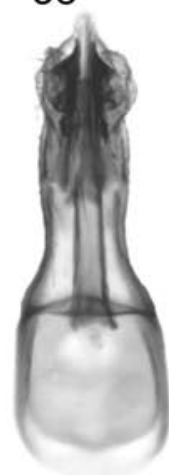

36

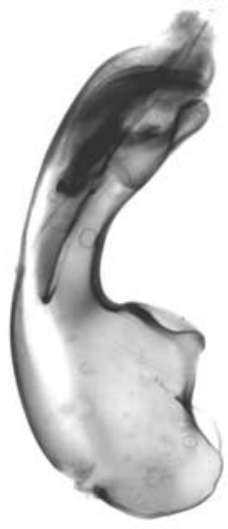

40

Figs 33-50: Aleochara conviva (33; Georgia), A. subtumida (34; Turkey), A. adusta (35-40; 35-36: lectotype; 37-39: Azerbaijan; 40: Iran), A. consors (41-42; lectotype), A. libanica (43-44; lectotype), A. sarica (45; paratype), A. feldmanni (46; holotype), A. caloderoides (47-48; holotype), and A. simplicicornis (49-50; holotype): median lobe of aedeagus in lateral view $(33-35,37,39-41,43,45-47,49)$; median lobe of aedeagus in ventral view $(36,38,42,44)$; apical portion of median lobe in ventral view $(48,50)$. Scale bar: $0.2 \mathrm{~mm}$. 


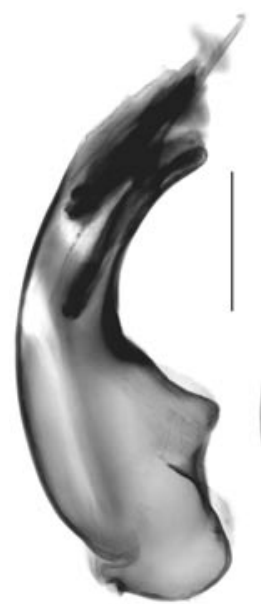

51

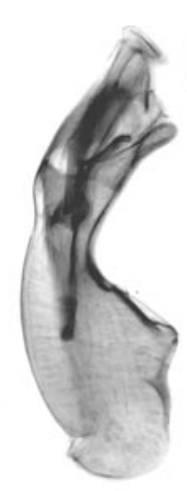

52
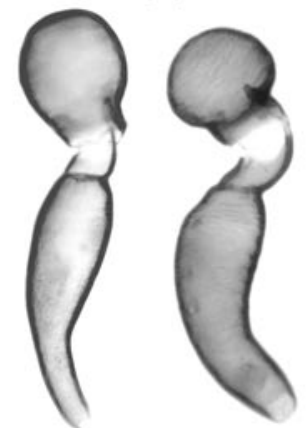

59

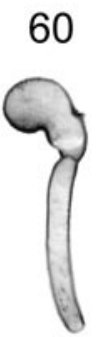

68

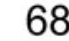

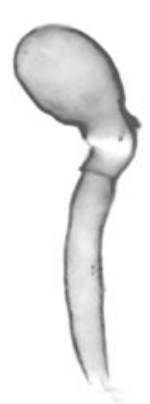

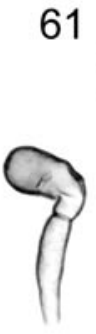

69
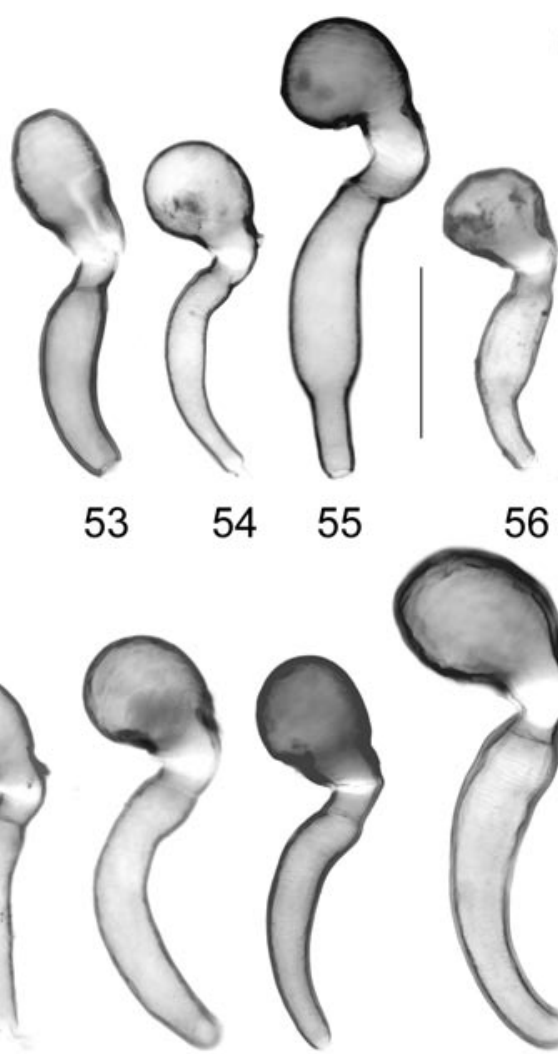

62
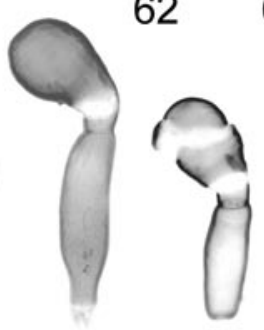

63

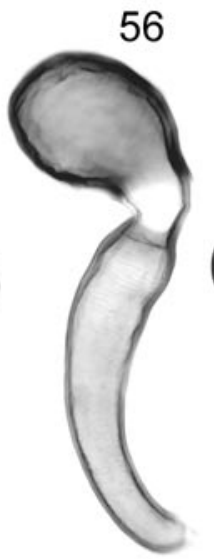

67

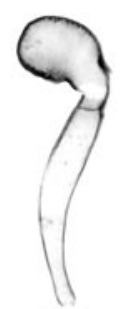

71

72

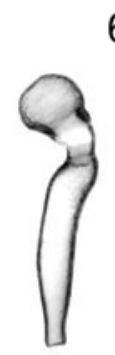

64
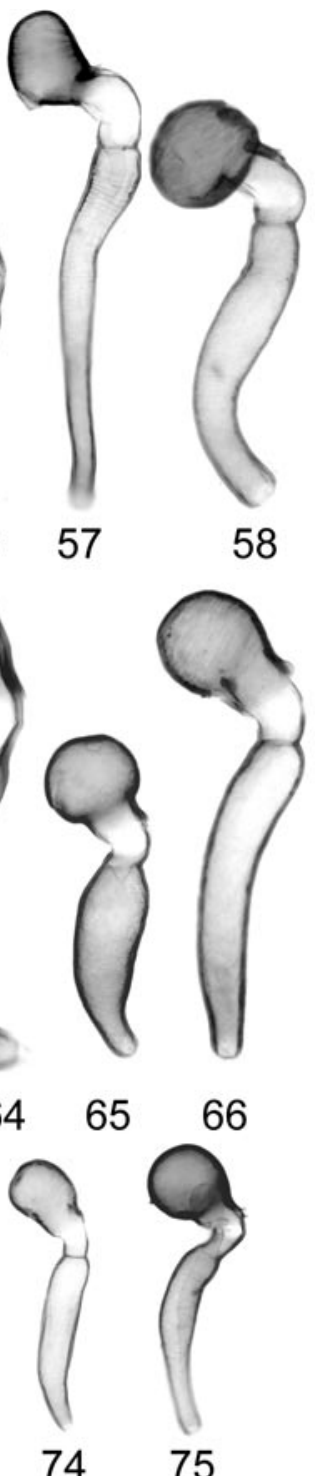

Figs 51-75: Aleochara conviva (51, 59; Turkey), A. mortuisimilis (52, 75; paratypes), A. ruficornis (53; Germany), A. erythroptera (54; Turkey), A. ganglbaueri (55; Austria), A. diversicollis (56; paralectotype), A. major (57; Germany), A. penicillata (58; Austria), A. opacina (60; France), A. strasseri (61-62; 61: BosniaHerzegovina; 62: Greece), A. hydrocephala (63; Spain), A. purkynei (64; Greece), A. conviva (65; Georgia), A. subtumida (66; Turkey), A. claviculata (67; paratype), A. caloderoides (68; paratype), A. simplicicornis (69; paratype), A. adusta (70; paralectotype), A. consors (71; paralectotype), A. libanica (72; Israel), A. sarica (73; paratype), and $A$. bodemeyeri (74; syntype in SDEI): median lobe of aedeagus in lateral view (51-52); spermatheca (53-75). Scale bars: $0.2 \mathrm{~mm}$. 

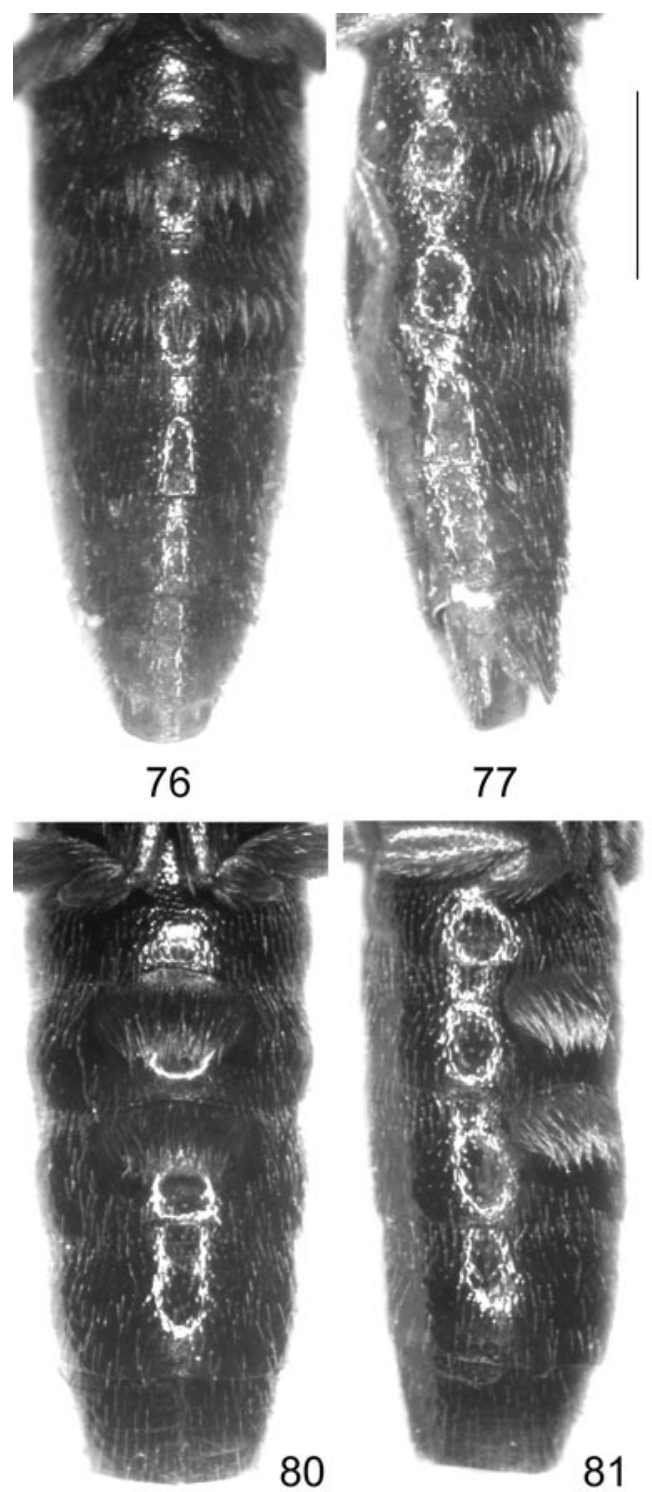

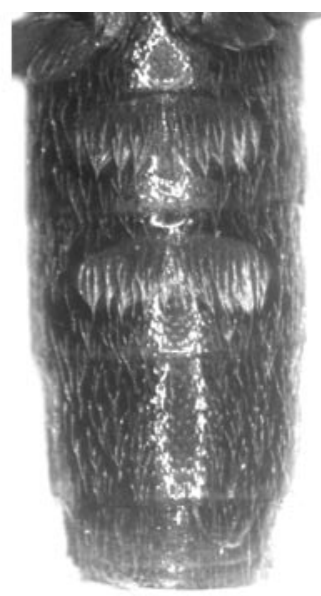

78

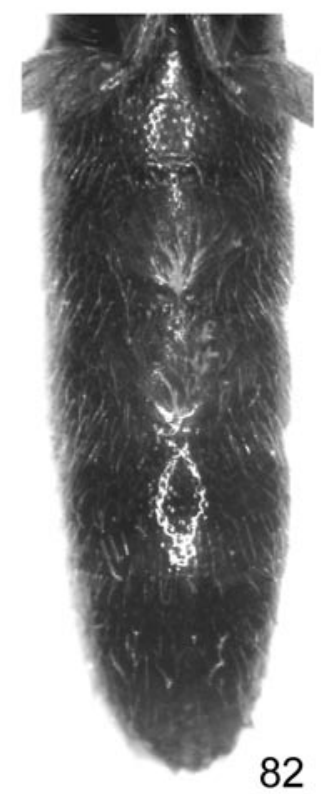

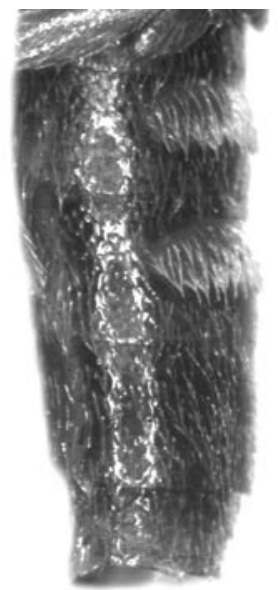

79

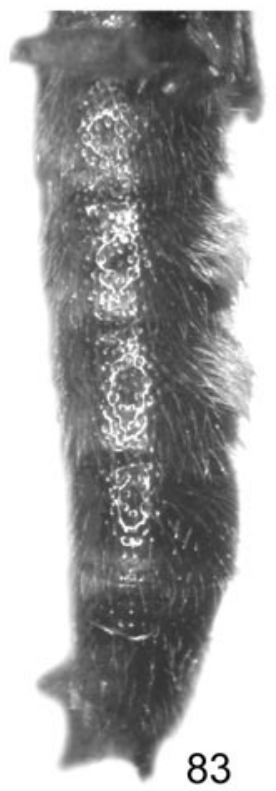

Figs 76-83: Aleochara ruficornis (76-77), A. ganglbaueri (78-79), A. diversicollis (80-81), and A. major (8283): male abdomen in ventral and in latero-ventral view. Scale bar: $1 \mathrm{~mm}$. 

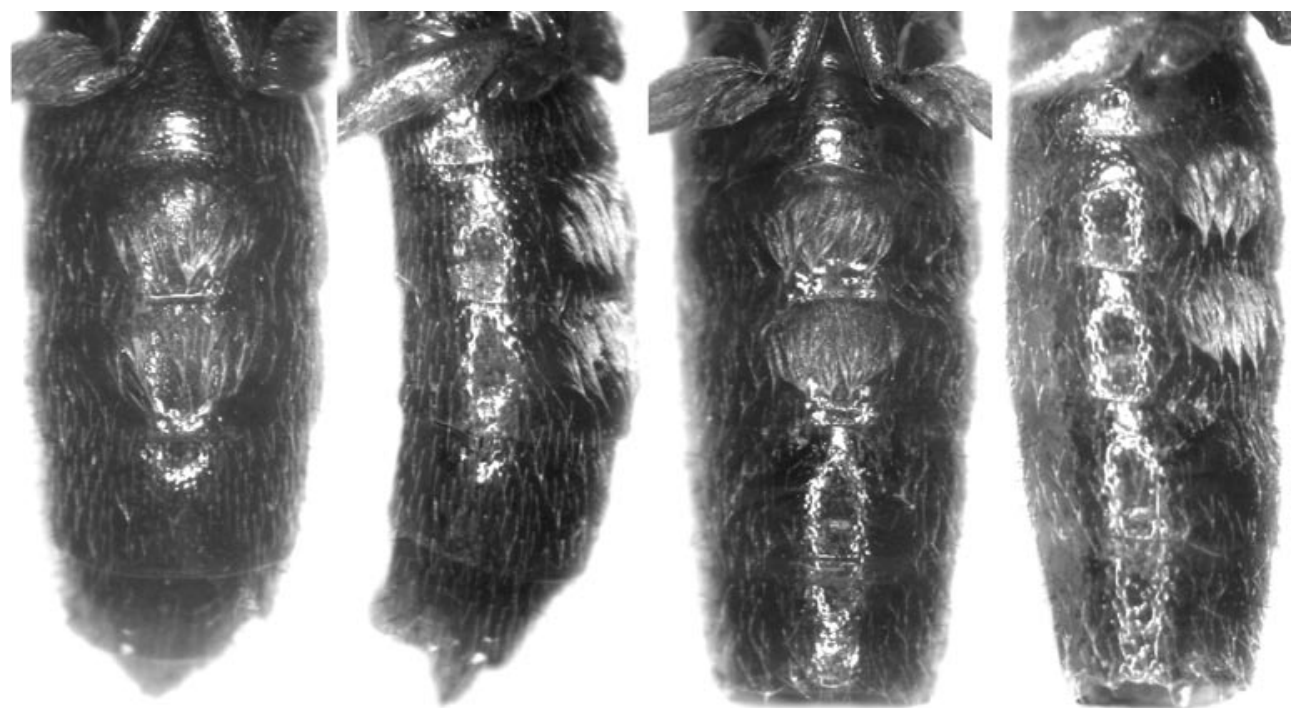

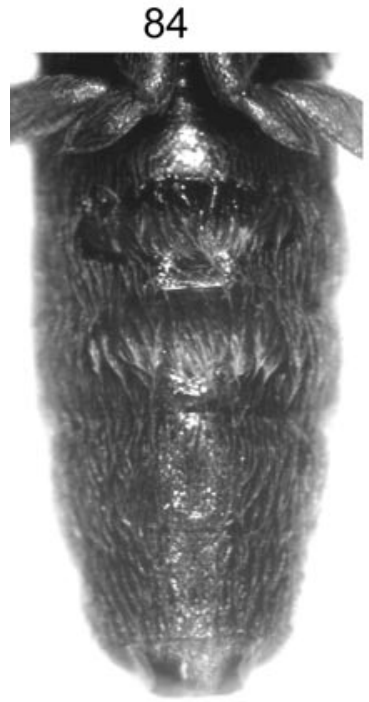

88

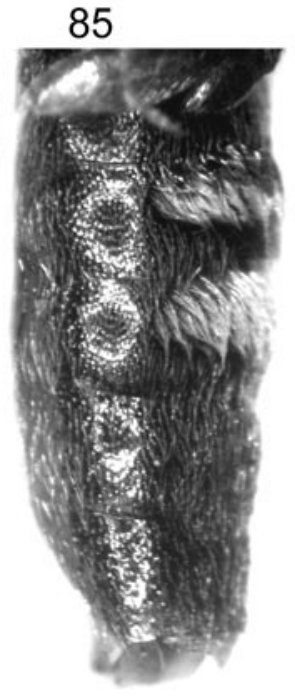

89

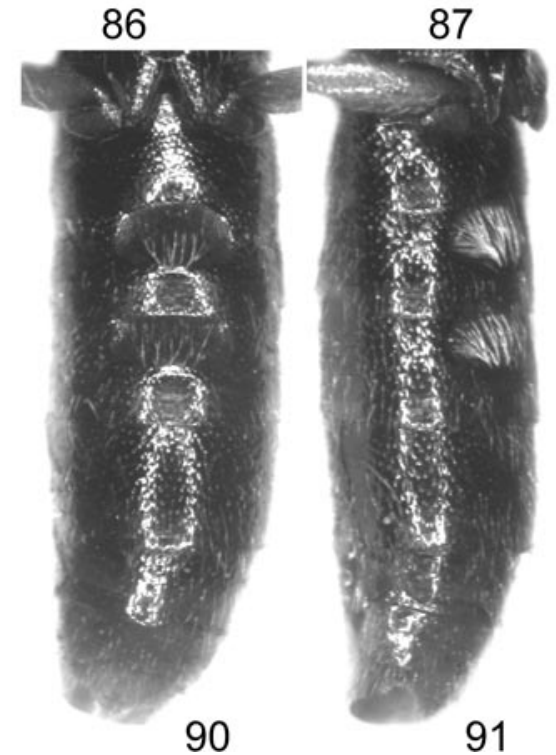

Figs 84-91: Aleochara melichari (84-85; lectotype), A. penicillata (86-87), A. opacina (88-89), and A. strasseri (90-91): male abdomen in ventral and in latero-ventral view. Scale bar: $1 \mathrm{~mm}$. 


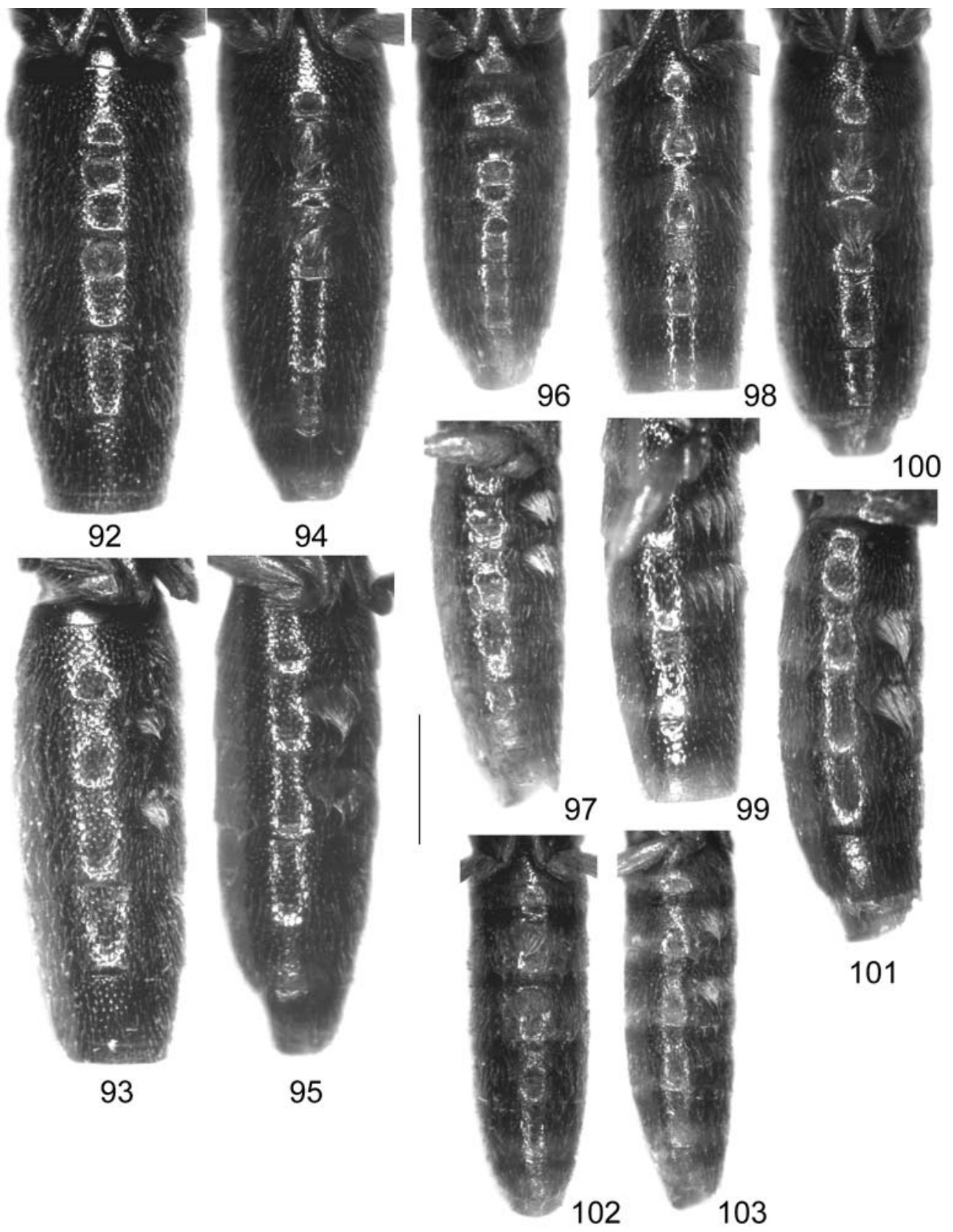

Figs 92-103: Aleochara purkynei (92-93), A. conviva (94-95; Georgia), A. hydrocephala (96-97), A. virilis (98-99), A. conviva (100-101; Turkey), and A. mortuisimilis (102-103): male abdomen in ventral and in latero-ventral view. Scale bar: $1 \mathrm{~mm}$. 


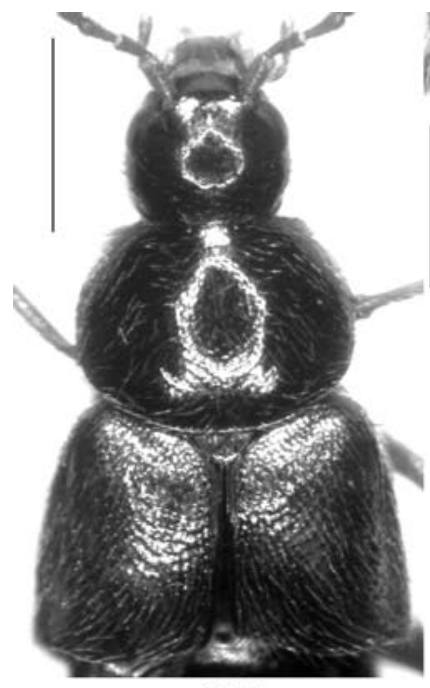

104

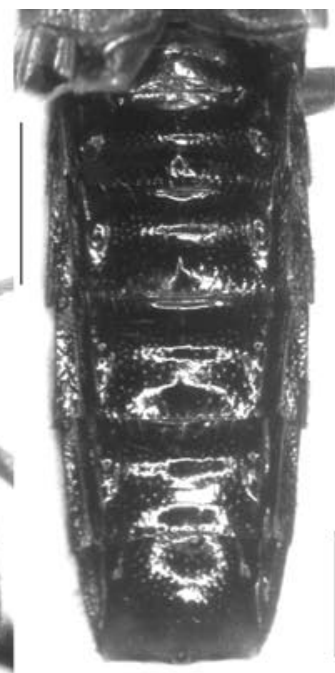

105

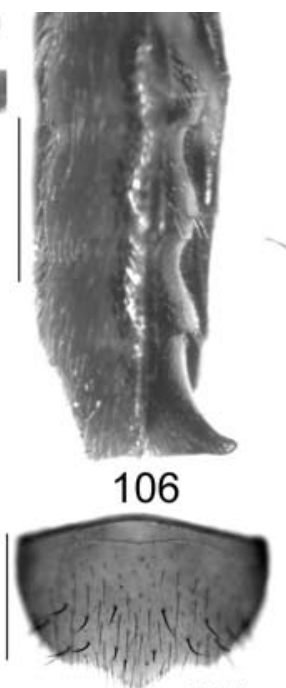

107

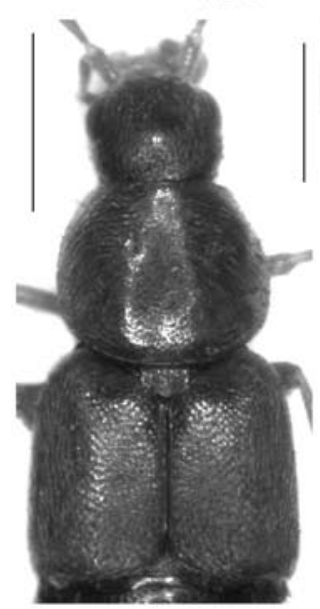

109

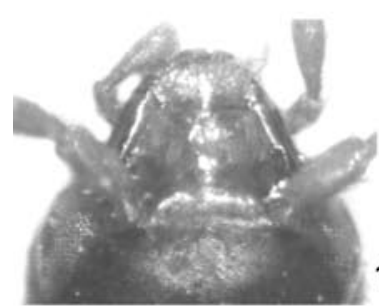

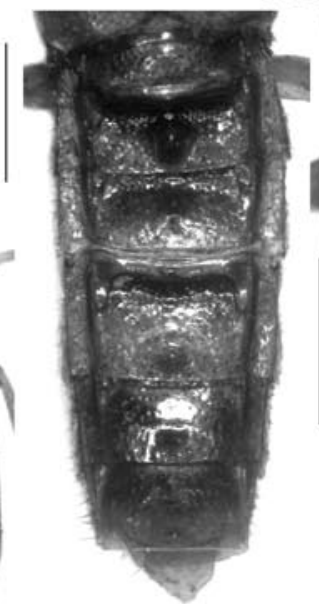

110

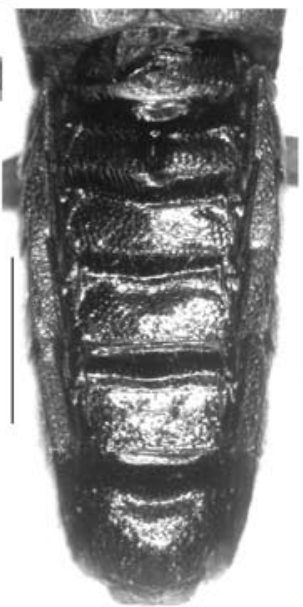

111

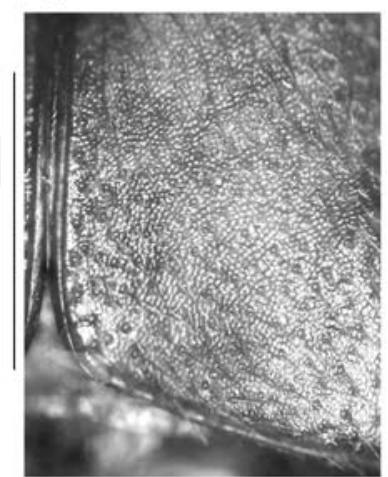

112

108

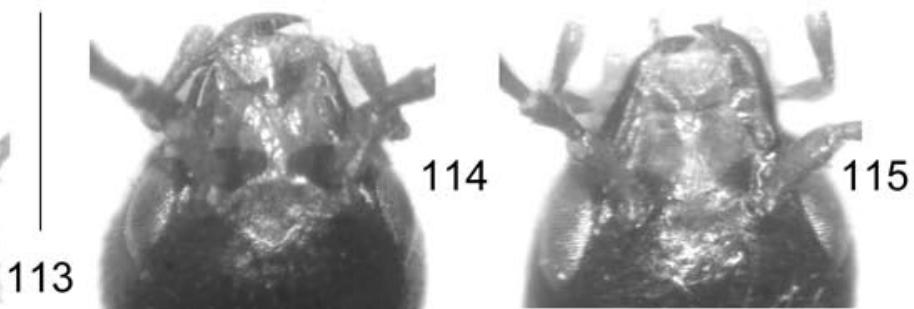

Figs 104-115: Aleochara diversicollis (104-107), A. melichari (108-110; lectotype), A. opacina (111-113), A. strasseri (114), and $A$. hydrocephala (115): forebody (104, 109); male abdomen in dorsal view (105, 110 111); male abdomen in lateral view (106); male sternite VIII (107); habitus (108); postero-median portion of elytra (112); anterior portion of head (113-115). Scale bars: 104-106, 108-111: 1.0 mm; 107, 112-115: $0.5 \mathrm{~mm}$. 

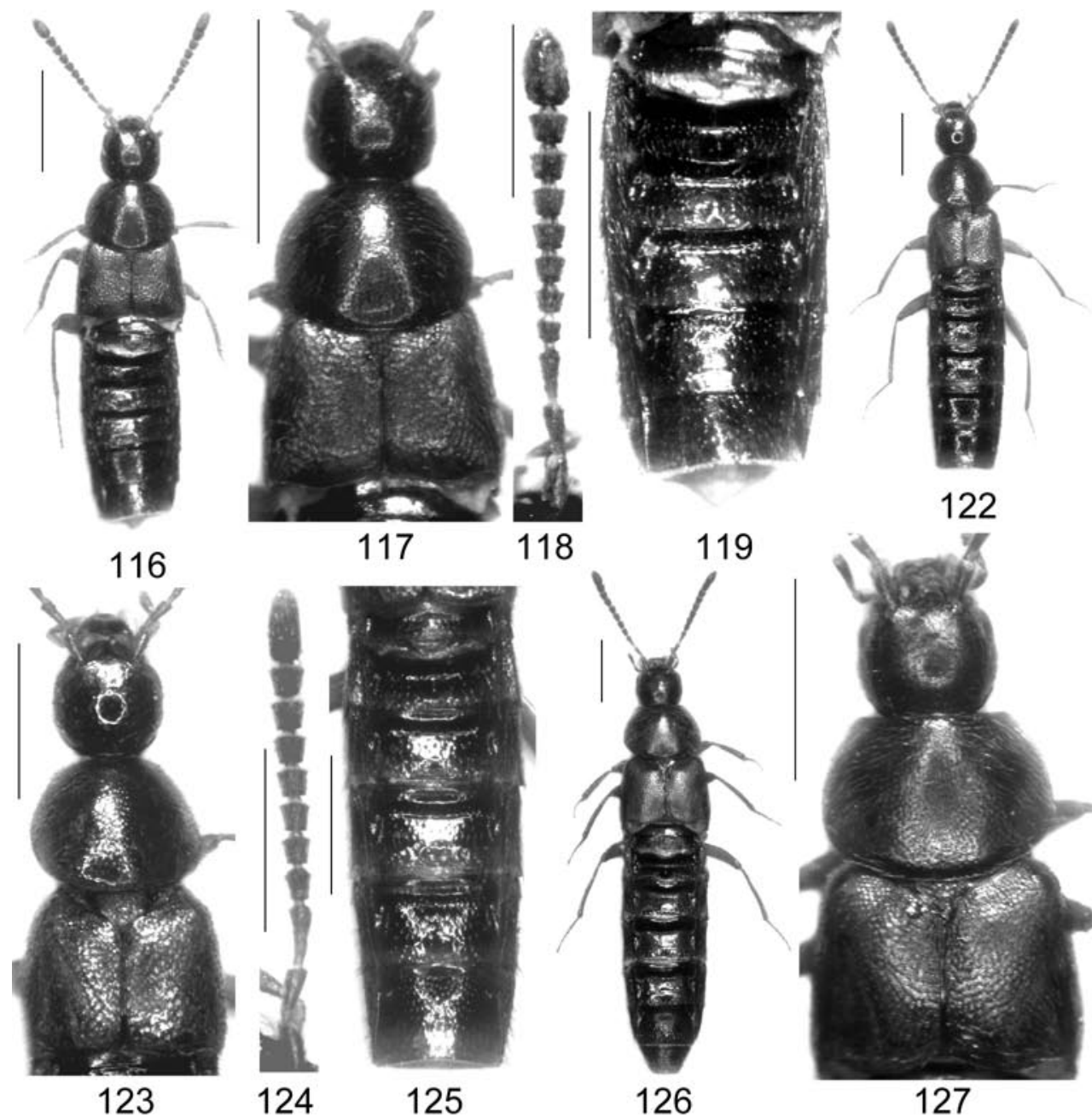

126

127

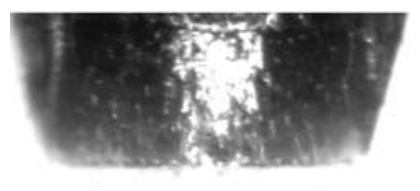

120

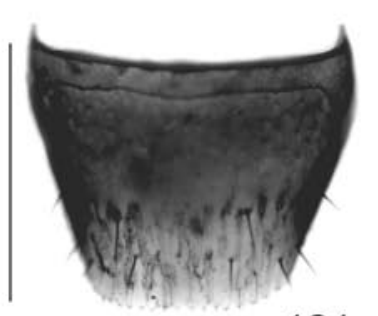

121

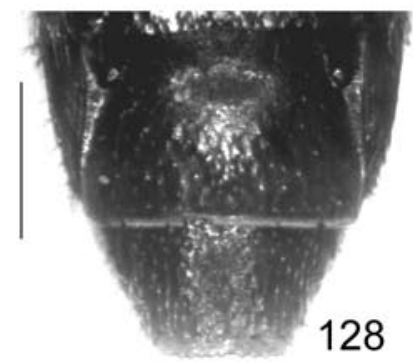

Figs 116-128: Aleochara caucasica (116-121; holotype), A. virilis (122-125; holotype), and A. conviva (126128; Georgia): habitus $(116,122,126)$; forebody $(117,123,127)$; antenna $(118,124)$; male abdomen in dorsal view $(119,125)$; male abdominal tergite VII (120); male tergite VIII (121); male tergites VII-VIII (128). Scale bars: 116-117, 119, 122-123, 125-127: $1.0 \mathrm{~mm} ; 118,120-121,124,128: 0.5 \mathrm{~mm}$. 


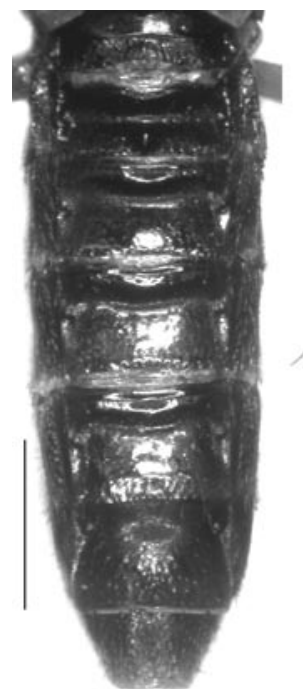

129

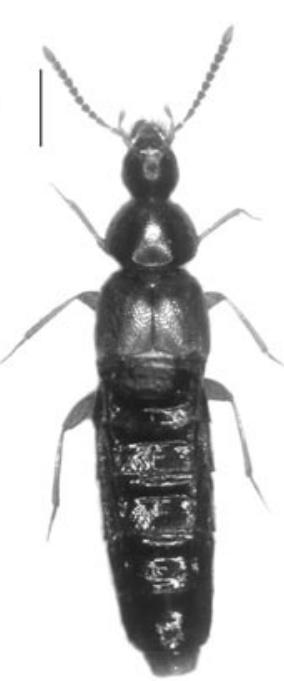

130

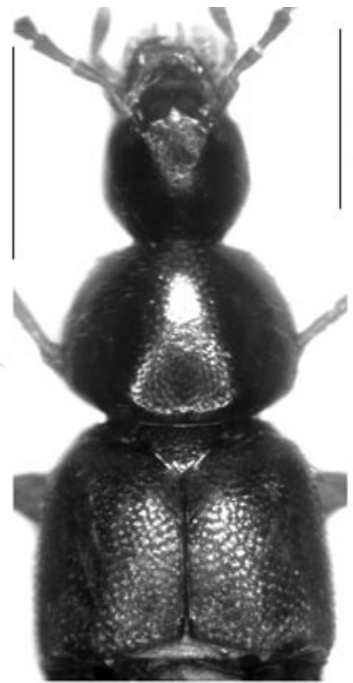

131

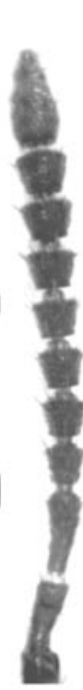

132

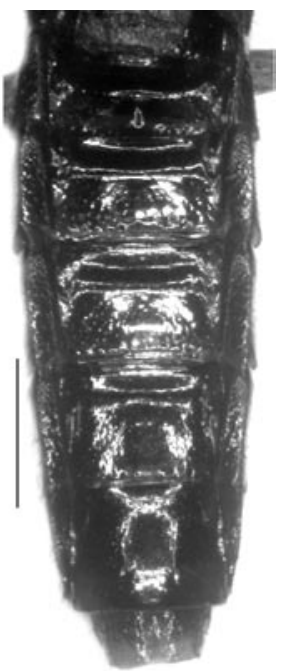

133

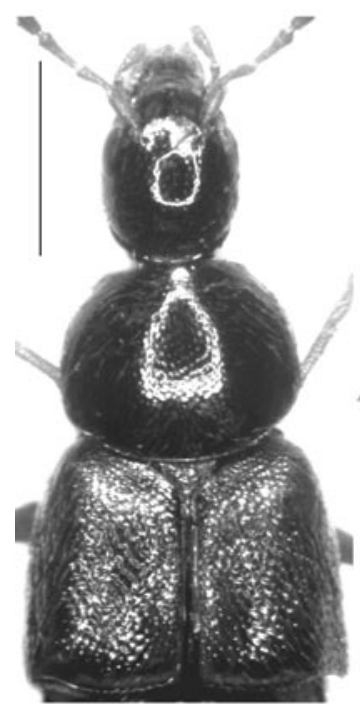

134

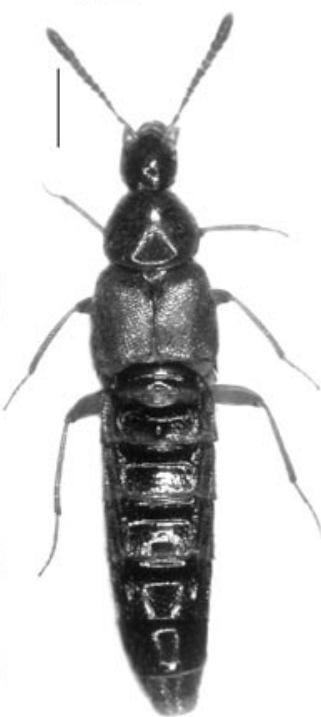

135

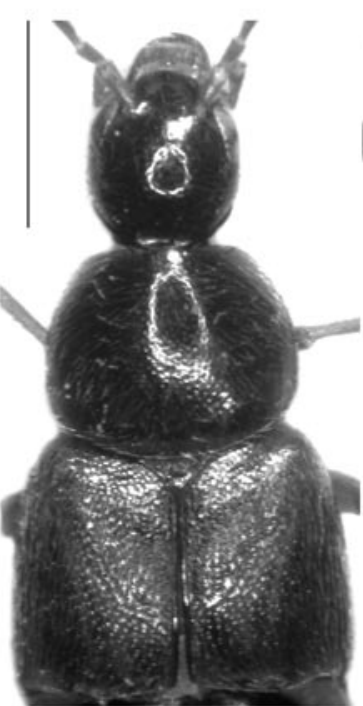

136

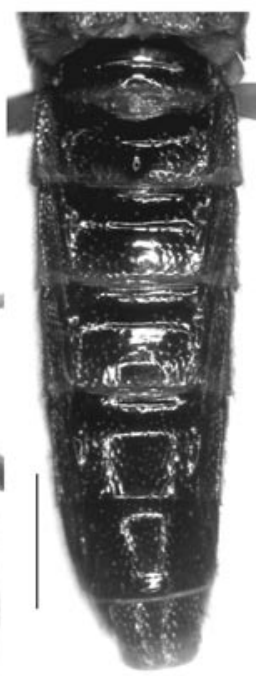

137

Figs 129-137: Aleochara conviva (129; Georgia), A. claviculata (130-133; holotype), A. subtumida (134), and $A$. adusta (135-137; Azerbaijan): male abdomen in dorsal view (129, 133, 137); habitus (130, 135); forebody $(131,134,136)$; antenna (132). Scale bars: 129-131, 133-137: $1.0 \mathrm{~mm}$; 132: $0.5 \mathrm{~mm}$. 


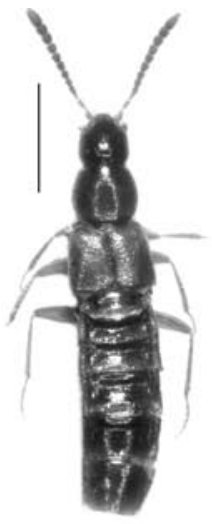

138

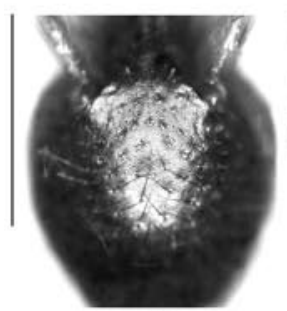

146

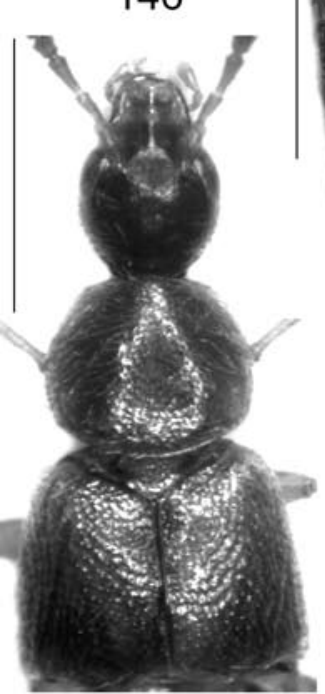

145

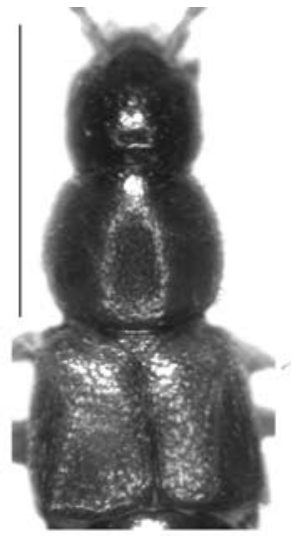

139

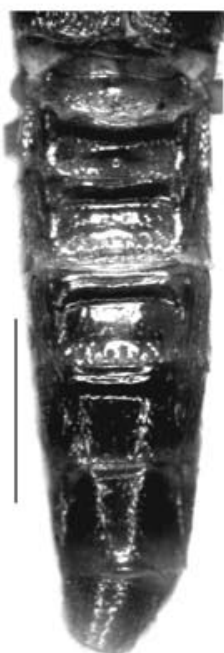

147
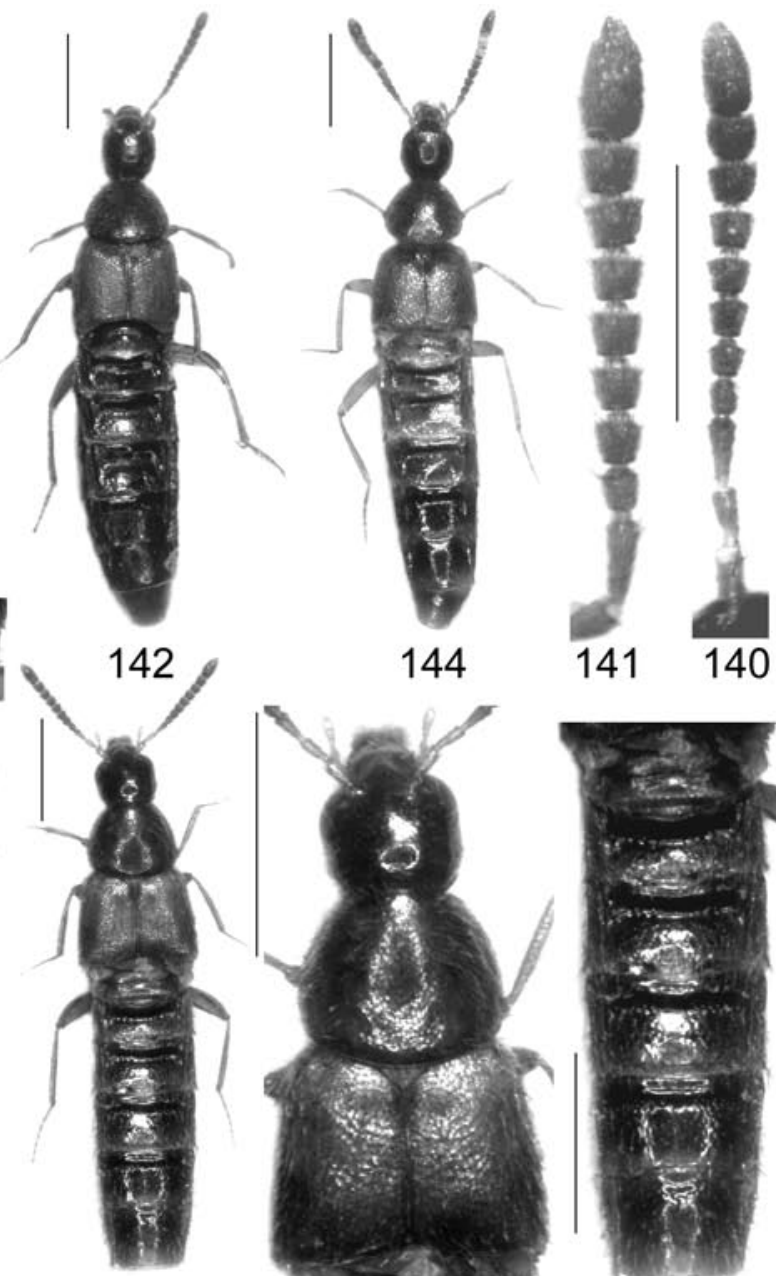

148

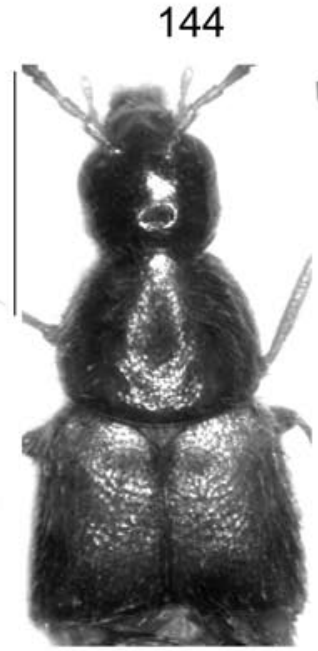

149

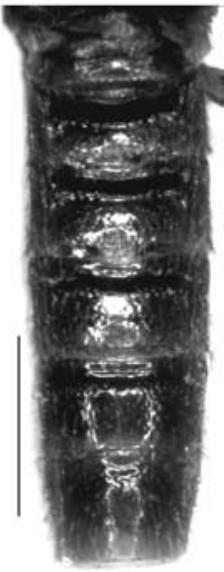

150

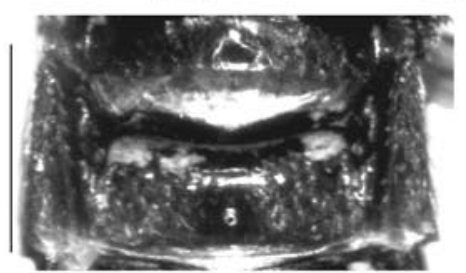

143

Figs 138-150: Aleochara consors (138-140; lectotype), A. adusta (141; lectotype), A. libanica (142-143, lectotype), A. sarica (144-147, paratype), and A. feldmanni (148-150; holotype): habitus (138, 142, 144, 148); forebody $(139,145,149)$; antenna (140-141); male abdominal tergite III (143); head (146); male abdomen in dorsal view $(147,150)$. Scale bars: 138-139, 142, 144-145, 147-150: $1.0 \mathrm{~mm} ; 140-141,143$, 146: $0.5 \mathrm{~mm}$. 

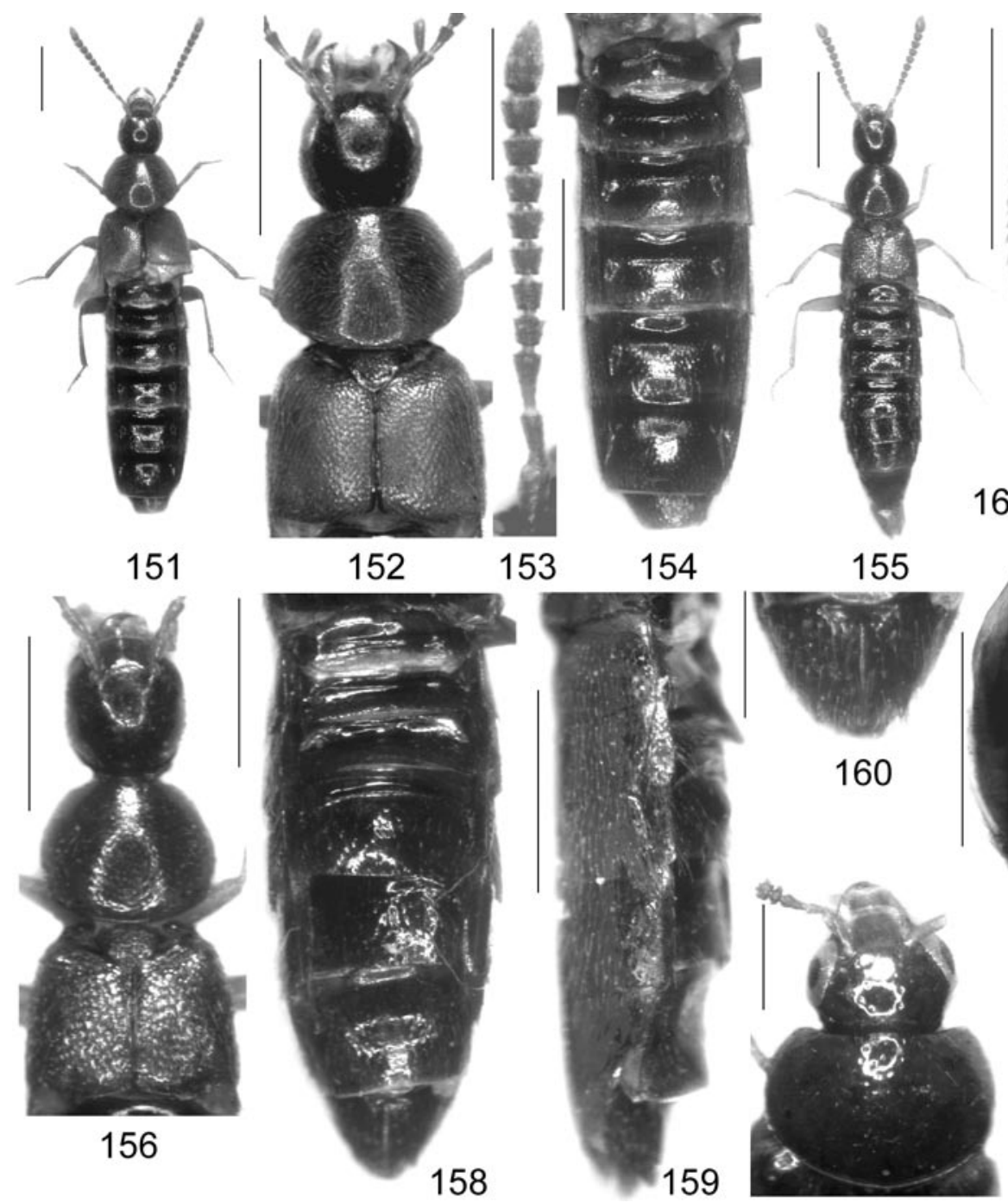

157

Figs 151-162: Aleochara conviva (151-154; Turkey), A. bodemeyeri (155-156; syntype from SDEI), and A. tuberiventris (157-162, syntype): habitus $(151,155)$; forebody $(152,156)$; antenna (153); male abdomen in dorsal view $(154,158)$; head and pronotum (157); male abdomen in lateral view (159); male abdominal tergite VIII (160); male mesotibia and mesotarsus (161); median lobe of aedeagus in lateral view (162). Scale bars: 151-152, 154-155, 158-159: $1.0 \mathrm{~mm}$; 153, 156-157, 160-162: $0.5 \mathrm{~mm}$. 


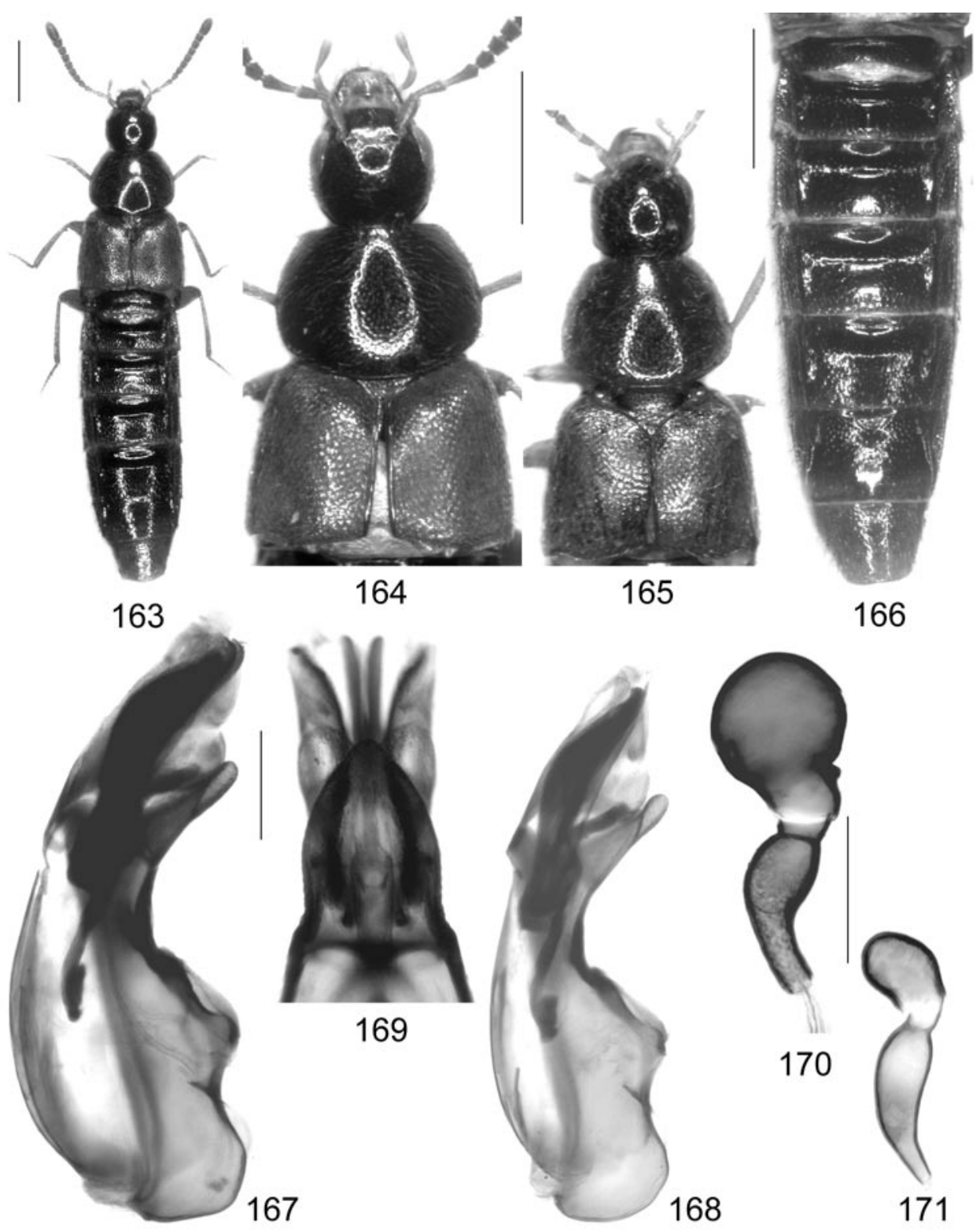

Figs 163-171: Aleochara bituberculata (163-170; 163-167, 169-170: Bolu; 168: Istanbul) and A. consors (171): female habitus (163); forebody (164-165); male abdomen in dorsal view (166); median lobe of aedeagus in lateral view (167-168); ventral process of aedeagus in ventral view (169); spermatheca (170-171). Scale bars: 163-166: $1.0 \mathrm{~mm}$; 167-171: $0.2 \mathrm{~mm}$. 


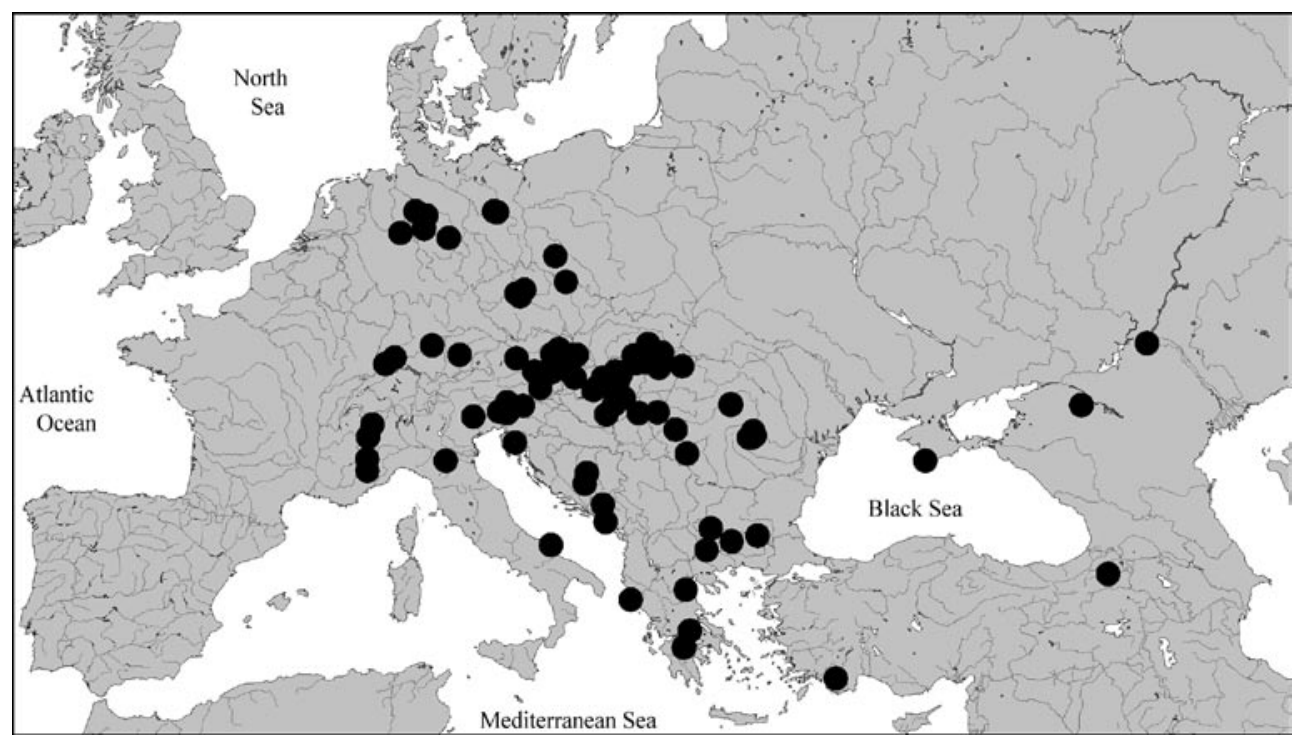

Map 1: Distribution of Aleochara erythroptera Gravenhorst, based on examined records.

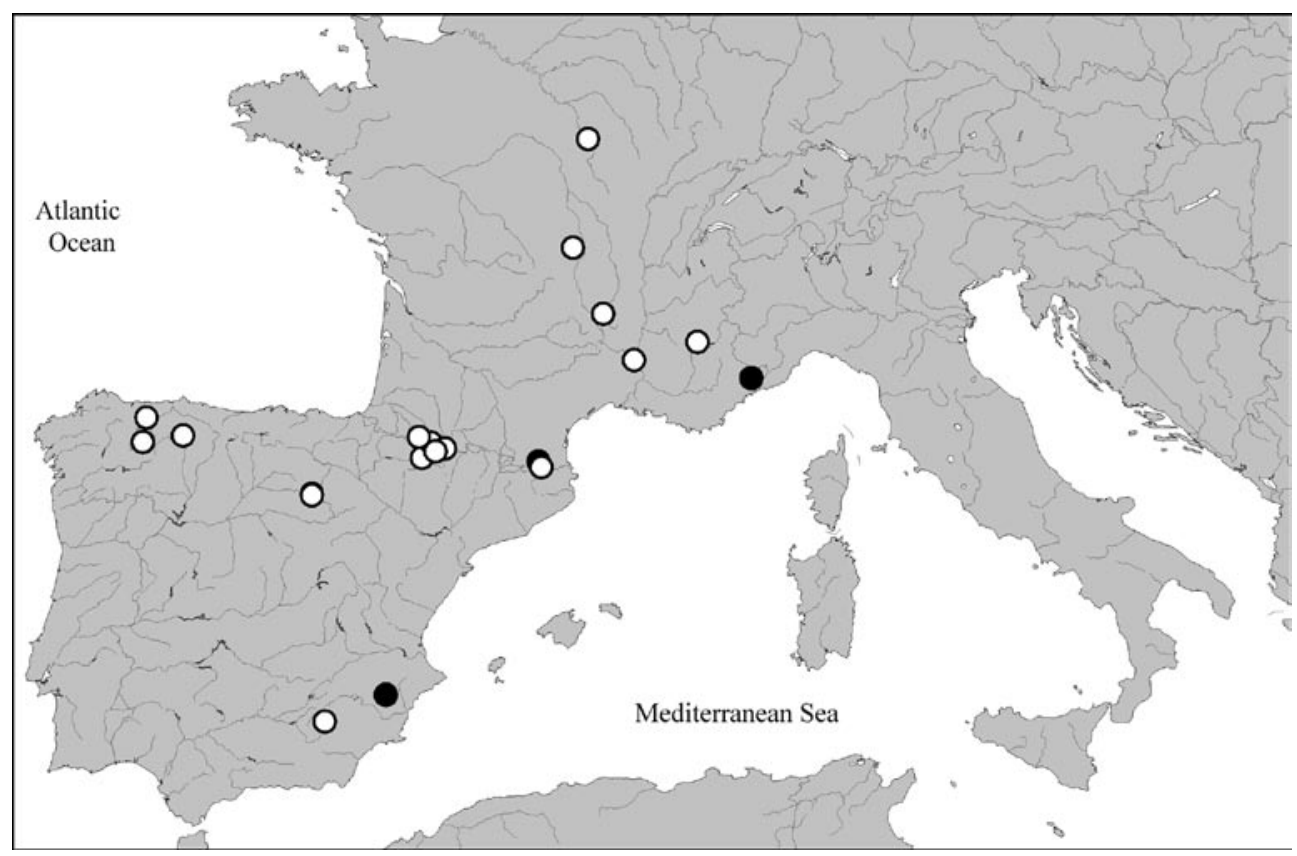

Map 2: Distributions of Aleochara hydrocephala FAUvel (open circles), based on examined and literature records, and of $A$. diversicollis FAUveL (filled circles), based on examined records. 


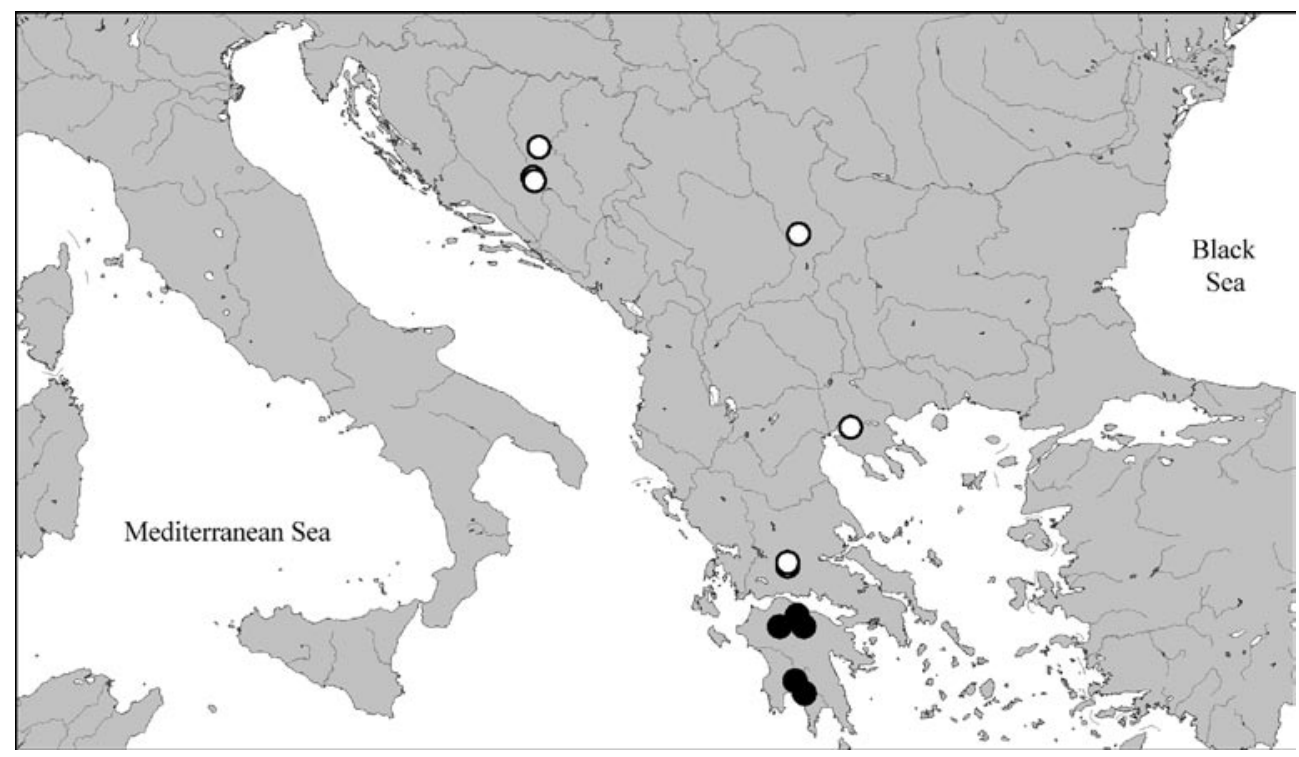

Map 3: Distributions of Aleochara strasseri Bernhauer (open circles) and of A. purkynei Roubal (filled circles), based on examined records.

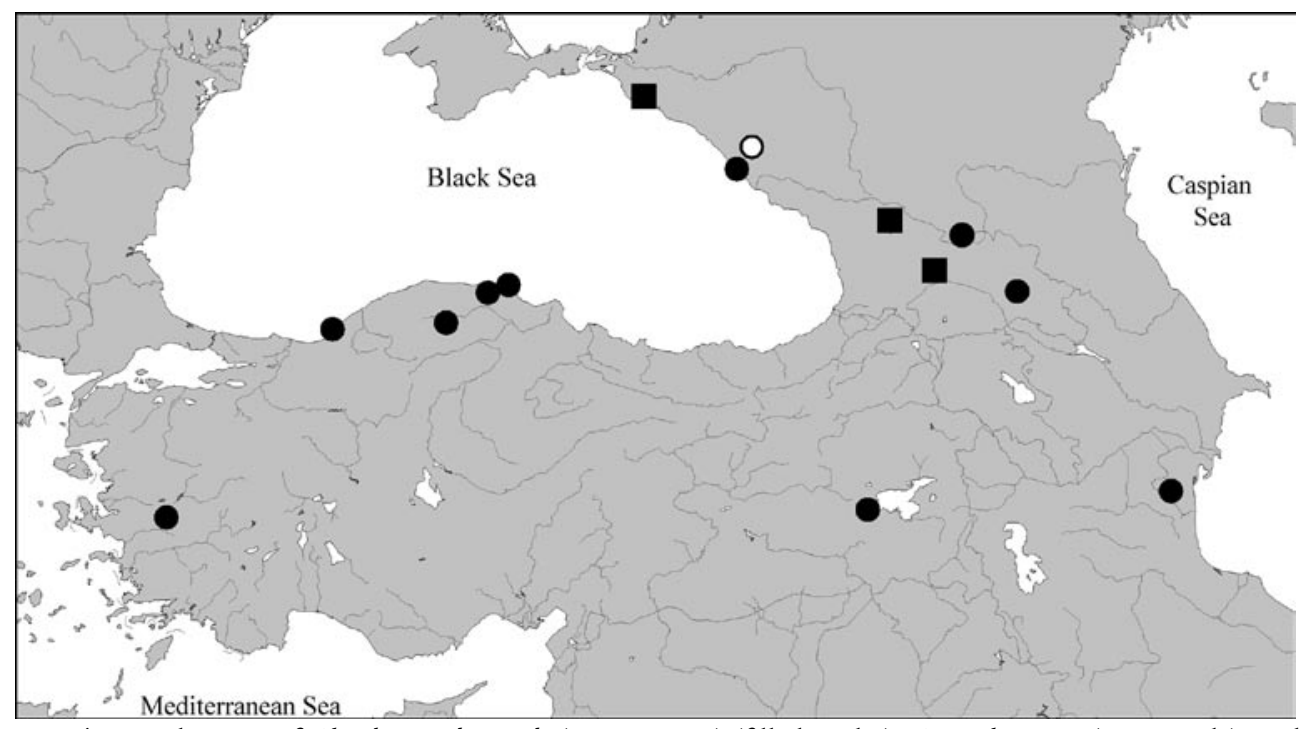

Map 4: Distributions of Aleochara subtumida (Носннuтн) (filled circles), A. virilis sp. n. (open circle), and A. caucasica Eppelsheim (squares), based on examined records. 